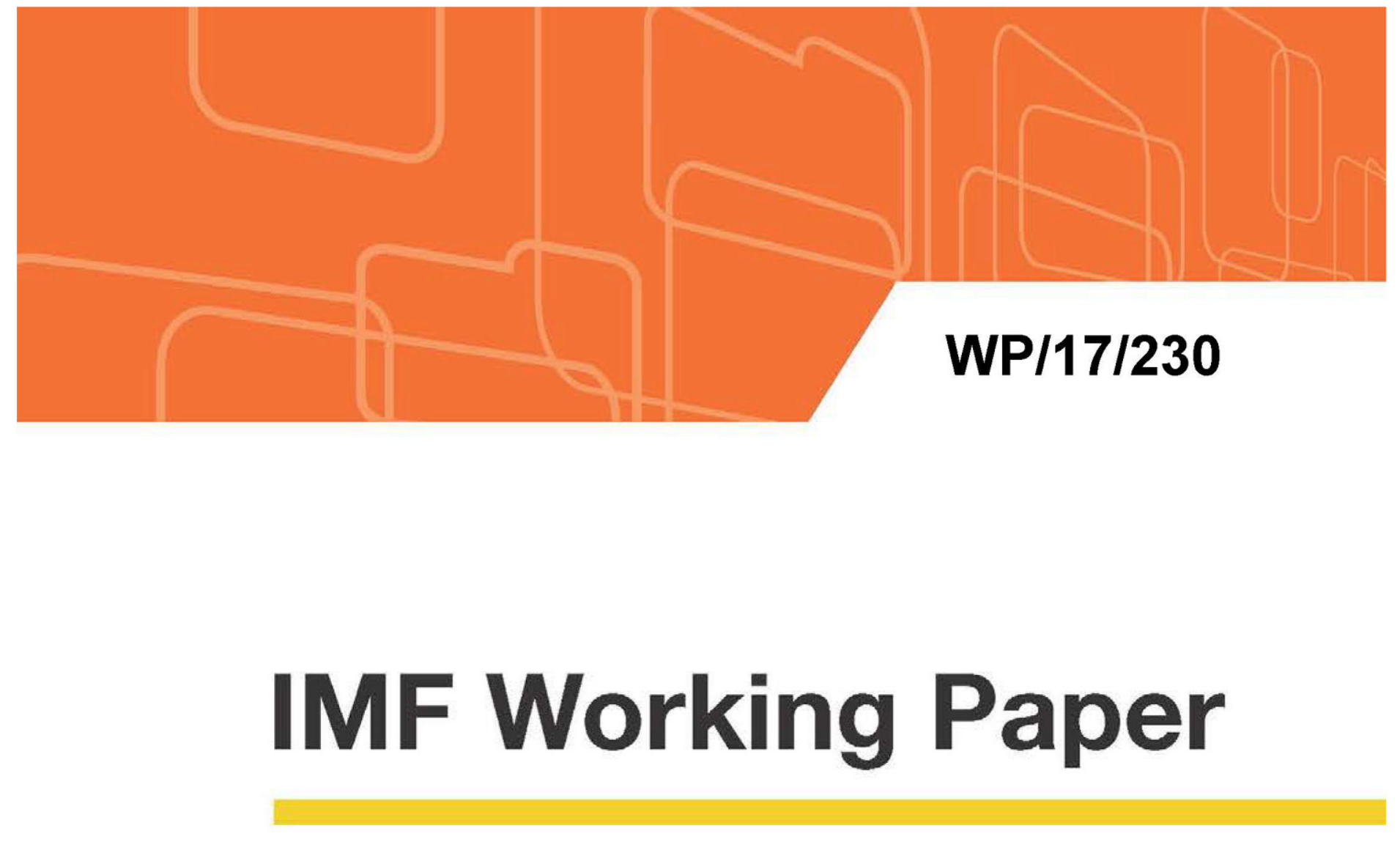

\title{
Problem Loans in the Caribbean: Determinants, Impact and Strategies for Resolution
}

by Kimberly Beaton, Thomas Dowling, Dmitriy Kovtun, Franz Loyola, Alla Myrvoda, Joel Okwuokei, Inci Otker and Jarkko Turunen

IMF Working Papers describe research in progress by the author(s) and are published to elicit comments and to encourage debate. The views expressed in IMF Working Papers are those of the author(s) and do not necessarily represent the views of the IMF, its Executive Board, or IMF management. 


\section{WP/17/230}

\section{IMF Working Paper}

\section{Problem Loans in the Caribbean: Determinants, Impact and Strategies for Resolution}

by Kimberly Beaton, Thomas Dowling, Dmitriy Kovtun, Franz Loyola, Alla Myrvoda, Joel Okwuokei, Inci Otker and Jarkko Turunen

IMF Working Papers describe research in progress by the author(s) and are published to elicit comments and to encourage debate. The views expressed in IMF Working Papers are those of the author(s) and do not necessarily represent the views of the IMF, its Executive Board, or IMF management.

$$
\text { I N T ER N A T I O N A L M O NETAR Y FU N D }
$$




\title{
IMF Working Paper
}

Western Hemisphere Department

Problem Loans in the Caribbean: Determinants, Impact and Strategies for Resolution

\section{Prepared by Kimberly Beaton, Thomas Dowling, Dmitriy Kovtun, Franz Loyola, Alla Myrvoda, Joel Okwuokei, İnci Ötker and Jarkko Turunen ${ }^{1}$}

\author{
Authorized for distribution by İnci Ötker
}

November 2017

IMF Working Papers describe research in progress by the author(s) and are published to elicit comments and to encourage debate. The views expressed in IMF Working Papers are those of the author(s) and do not necessarily represent the views of the IMF, its Executive Board, or IMF management.

\begin{abstract}
The high level of nonperforming loans (NPLs) in the Caribbean has been, in large part, a legacy of the global financial crisis, but their persistence owes much to the weak economic recovery in the region, as well as to structural obstacles to their resolution. A comprehensive strategy is needed to address these impediments to sever the adverse feedback loops between weak economic activity and weak asset quality. This paper finds that NPLs are a drag on Caribbean growth and macro-financial links are strong: a deterioration in asset quality hinders bank lending and dampens economic activity, undermining, in turn, efforts to resolve problem loans. A multifaceted approach is needed, involving a combination of macroeconomic policies to support growth and employment; strong supervisory frameworks to ensure macro-financial stability and create incentives for resolution; efforts to address informational gaps and deficiencies in insolvency and debt-enforcement frameworks; and development of markets for distressed loans. The institutional capacity constraints require coordination of reforms within the region and support from international organizations through capacity-building.
\end{abstract}

JEL Classification Numbers: E32, E44, E51, G21

Keywords: Macro-financial linkages, nonperforming loans, resolution, the Caribbean Author's E-Mail Address: KBeaton@imf.org; TDowling@imf.org; DKovtun@imf.org; AMyrvoda@imf.org; JOkwuokei@imf.org; IOtker@imf.org; JTurunen@imf.org

\footnotetext{
${ }^{1}$ The authors are grateful for the contributions of Shelton Nicholls and for the valuable comments and suggestions from Krishna Srinivasan, Dermot Monaghan, Diarmuid Murphy, Anjum Rosha, and the authorities of The Bahamas, Barbados, the ECCB, and Jamaica, and Suriname. The authors thank the banks and country authorities who participated in the surveys on impediments to NPL resolution and provided bank-by-bank and country-level data underlying the paper's analyses. All errors are the authors' responsibility.
} 


\section{Contents}

Abstract __ 2

I. Introduction $\quad \underline{5}$

II. Taking Stock: How Serious is the Problem? __ $\underline{7}$

III. Macro-Financial Implications of High NPLs __

A. Analyzing Macro-Financial Linkages: Data and Methodology ___

B. Results

IV. Determinants of NPLs __ 13

A. Data and Methodology _

B. Results

V. Obstacles to NPL Resolution __ 16

A. Prudential and Supervisory Framework and NPL Management __

B. Debt-Enforcement and Insolvency Framework _ 22

C. Data Gaps and Impediments to Information Sharing __

D. Market for NPLs

E. Tax Regime Obstacles _

VI. Way Forward: Strategy for NPL Resolution __ 26

References __ $\underline{30}$

Tables

1. Correlation Across Macro-Financial Variables

2. Macroeconomic Determinants of NPLs

3. Bank-Level Determinants of NPLs: Bank Performance___

Figures

1. NPLs in the Caribbean $\underline{5}$

2. NPLs and Real GDP Growth

3. Cross-Country NPLs and Provisions

4. Caribbean NPLs by Economic Sector

5. Bank-Level NPLs and Provisioning __ 9

6. NPLs, Bank Profitability, Private Credit \& Economic Activity ___

7. PVAR Results

8. Top Obstacles to NPL Resolution in the Caribbean

9. The Caribbean: Survey-Based Scores on Obstacles to NPL Resolution by Country ___

10. International Comparison 20

11. Ratio of Loan Loss Provisions to NPLs 21

12. Use of debt restructing and NPL Disposal Tools

13. Dealing with Insolvency: Time to Complete and the Cost of Insolvency ___

14. Information Obstacles

15. Restrictions in the Market for Distressed Assets __ 25

16. Disincentives in the Taxation Framework

17. Strategy to Address the Obstacles to NPL Resolution ___ 


\section{Boxes}

1. Measuring Asset Quality: Challenges and Alternative Approaches

2. Asset Management Companies (AMCs) in the Caribbean

Annexes

I. Case Studies on Resolving NPLs in Selected Caribbean Countries $\underline{32}$

II. Key Measures Implemented in the Past 3 Years to Resolve NPLs

III. Macro-Financial Linkages in the Caribbean: Impulse Responses from Panel VAR $\underline{45}$

IV. Results of the Detailed Empirical Analyses and Survey Responses 


\section{INTRODUCTION}

The Caribbean region weathered the global financial crisis relatively well, but the quality of bank assets gradually deteriorated during the ensuing economic recession, leaving many countries with elevated levels of problem loans. Notwithstanding significant heterogeneity across the region, the share of nonperforming loans (NPLs) in total loans (a commonly used measure of asset quality, Box 1), which was relatively low before the global financial crisis, rose to more than 10 percent in 2016 across several Caribbean countries, peaking around 15 percent for many countries over the period 2007-16 (Figures 1 and 2). The increase in NPLs was more significant in tourism-dependent countries compared with commodity exporters. NPL ratios in many countries have been slow to decline from their elevated levels, owing to structural and institutional impediments to resolution, as well as subdued or declining loan growth and sluggish economic activity, but in a number of countries, NPL ratios have started to fall from their peaks, owing to increased efforts undertaken by country authorities and banks to reduce impaired assets.

The persistently high level of NPLs poses significant macroeconomic and financial stability challenges to the region. With their balance sheets plagued by impaired loans, banks restrain credit supply, with an effect that is likely to be particularly strong in the Caribbean context given the bank-dominated financial systems. With persistent NPLs constraining the supply of funding to the private sector and weak growth prospects dampening credit demand, distressed borrowers curtail consumption and investment, hindering economic growth. High NPLs also increase banks' vulnerability to shocks by reducing their profitability, tying up their capital, and raising funding costs. As such, banks with high NPLs present a potential risk to financial stability in the region.

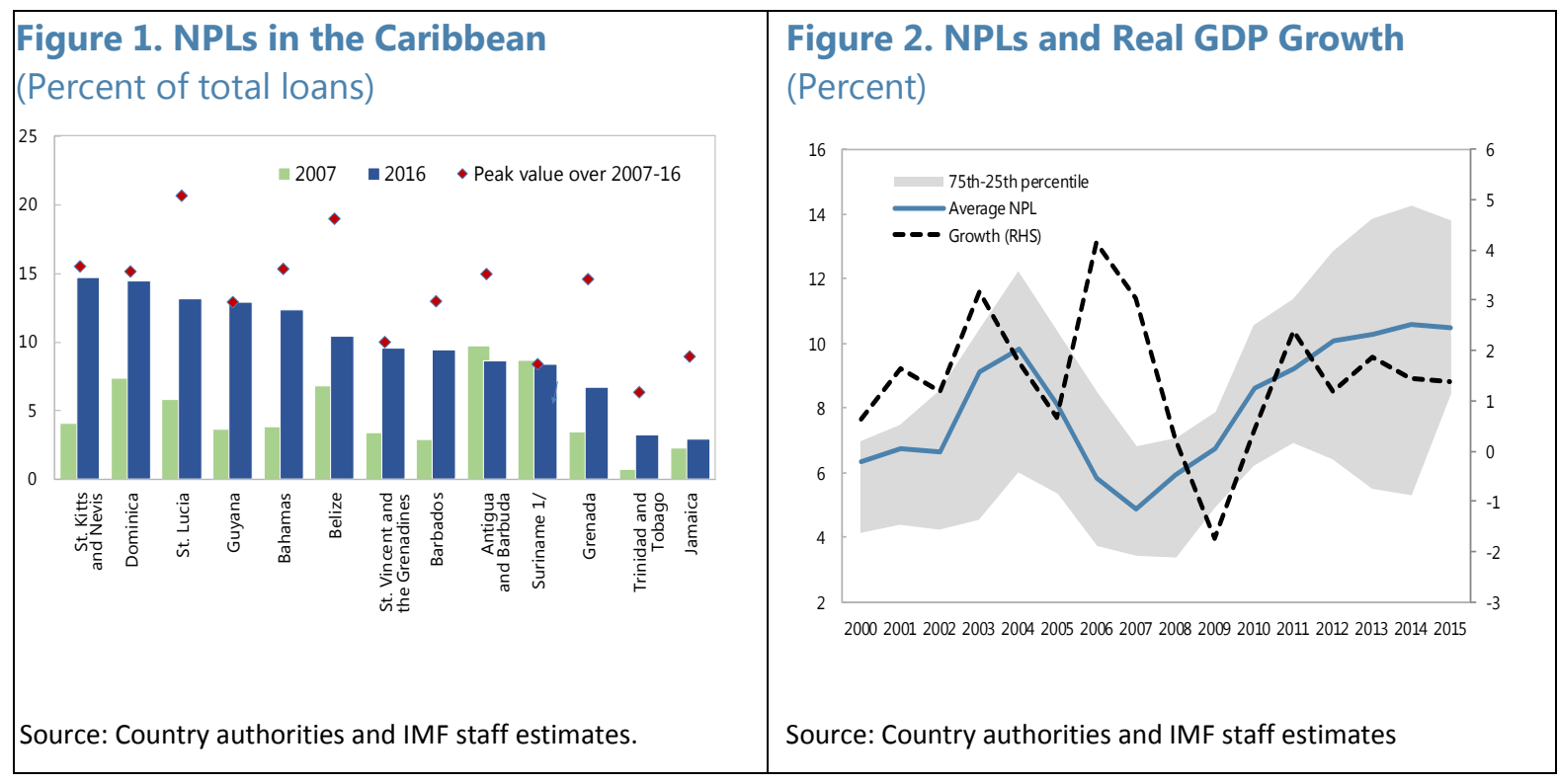

This paper analyzes the determinants and consequences of NPLs in the Caribbean, explores possible obstacles to their resolution, and suggests a way forward. It first takes stock of the NPL problem and analyzes its characteristics and evolution. It then examines the determinants of NPLs and their importance as a driver of macro-financial feedback loops. Finally, it explores the main impediments to the resolution of problem loans in the region to draw policy implications for addressing the problem. To address these objectives, the paper uses three complementary approaches. 
First, a panel vector autoregression (VAR) analysis uses country-level data to examine macro-financial links between NPLs, credit growth, and economic activity in the Caribbean economies. Empirical evidence confirms strong macro-financial links, with deteriorating asset quality lowering private credit growth and spilling over into the broader economy by depressing economic activity and resulting in higher unemployment. An improved macroeconomic environment, however, enhances borrowers' debt-service capacity and, other things being equal, results in lower NPLs. ${ }^{2}$

\section{Box 1. Measuring Asset Quality: Challenges and Alternative Approaches}

The analysis in this paper measures asset quality using the NPL ratio, a commonly used Financial Soundness Indicator (FSI) in cross-country analyses and is included in a core set of FSIs, compiled by most jurisdictions. The core FSI set includes two other measures of asset quality: sectoral distribution of loans to total loans (presented in the descriptive statistics) and a ratio of NPLs net of provisioning to capital (not considered in this paper due to the lack of comparable data on provisioning).

Notwithstanding its wide applicability, the NPL ratio has several shortcomings. These include (i) lack of harmonization of national definitions, (ii) differences in the treatment of restructured loans and a "blind spot" regarding forbearance, creating uncertainty around the treatment of restructured loans in many jurisdictions, (iii) its backward-looking nature (relying mostly on past due days and potentially missing forward-looking elements, such as a deterioration in the financial position of a debtor). These caveats prompted initiatives for further harmonization of definitions, such as technical standards on supervisory reporting on forbearance and nonperforming exposures in the EU and proposals by Basel Committee on Banking Supervision for guidelines on prudential treatment of problem assets. ${ }^{1}$

In principle, alternative approaches may be used to measure asset quality. Supervisory authorities generally issue guidelines on asset classification and provisioning that often define buckets such as "standard," "watch," "substandard," "doubtful," and "loss" for more granular monitoring of the quality of loan portfolios that may include some forward-looking features. In turn, banks develop grading systems based on internal risk rating models to estimate expected losses based on the probability of default (PD), the loss given default (LGD), and the exposure at default (EAD). Although these alternatives can potentially yield better insights into asset quality, the definitions and approaches are generally not comparable across jurisdictions, making their application in cross-country study challenging. In addition, data on these categorizations are rarely published.

${ }^{1}$ Bank for International Settlements (2016).

Second, dynamic panel regressions are used to analyze the determinants of NPLs using both country data and detailed bank-level data. The results suggest that deteriorating asset quality can be attributed to both macroeconomic and bank-specific factors. Specifically, NPLs are affected by the business cycle-low economic growth, including in advanced economies, weakens asset quality, particularly in tourism-dependent economies. After controlling for endogeneity between NPLs and bank fundamentals, results from similar regressions with a

\footnotetext{
2 These results are broadly consistent with those in Beaton, Myrvoda, and Thompson (2016) for the ECCU, Tintchev (forthcoming) for commodity-exporting Caribbean countries, Jordan and Tucker (2013) for The Bahamas, and similar studies for other regions (see, for example, Espinoza and Prasad 2010; Beck, Jakubík, and Piloiu 2013; Klein 2013; Nkusu 2011).
} 
novel bank-level data set also suggest that banks with weaker fundamentals (lower profitability, capital adequacy, and efficiency) also tend to suffer from weaker asset quality.

Third, a survey of regional authorities and commercial banks explores obstacles to NPL resolution in the Caribbean. Consistent with the empirical evidence, survey responses highlight low growth and high unemployment, as well as weaknesses in regional real estate markets, as determinants of high and persistent NPLs. In addition, the responses point to interrelated and mutually reinforcing structural obstacles to NPL resolution, including the lack of markets for distressed assets, gaps in information systems, and deficiencies in the legal system and insolvency and debt-enforcement regimes.

The findings of this paper suggest that problem loans should be tackled on multiple fronts. In addition to pursuing policies aimed at securing strong and sustainable growth and prudential policies to limit excessive risk taking during loan origination, the authorities should develop targeted strategies for addressing structural obstacles to the resolution of NPLs. Policies should aim to address information gaps and eliminate impediments to information sharing to facilitate valuation of collateral and development of markets for distressed assets; address deficiencies in insolvency and debt-enforcement frameworks to accelerate and maximize recovery, including through strengthening judicial systems; and establish conditions for nonbanks specialized in servicing problem loans to facilitate collection and disposal of distressed assets. Requiring provisioning independent of collateral values could ensure swift write-off. Consideration could also be given to establishing a panCaribbean market for problem loans that would be open to external investors.

\section{Taking Stock: How Serious Is the Problem?}

NPLs have risen sharply across the Caribbean following the global financial crisis. Banking systems in many countries have been plagued by high ratios of NPLs, which, except in Jamaica and Trinidad and Tobago, exceed prudential norms (typically around 5 percent). The average NPL ratio across the Caribbean is also high compared with most other regions in the world. Country-level data for the past 20 years point to a significant deterioration of bank asset quality after the global financial crisis. Elsewhere in the region, for example, in Latin America, the impact was more subdued (Figure 3). This outcome could be attributed to stronger macroeconomic fundamentals, on average, in Latin America compared with the Caribbean, greater export diversification, and relatively weaker links to advanced economies, especially the United States. Moreover, subdued bank profitability has limited the ability of many banks to adequately provision for problem loans, with provisioning to NPLs low by international comparison, averaging at about 60 percent, though with significant variation across the region (e.g. in Jamaica, provisions are over 100 percent; Annex 1).

High NPLs in the Caribbean are, in large part, a legacy of the global financial crisis, but also reflects structural problems. Before the crisis, credit growth was strong, spurred by economic activity in the tourism industry and related construction, as well as by favorable global commodity prices for the commodity-exporting Caribbean countries. Credit expansion led to higher private and public sector debt, increasing borrowers' vulnerability to shocks and banks' exposure to credit risk. The crisis was transmitted to the region primarily through lower demand for the region's tourism services. Reduced tourist arrivals had a significant negative impact on tourism-dependent sectors and related construction, resulting in a sharp increase in unemployment and loss of income for households, which, in turn, impaired their ability to service their loans. As a result, the increase in NPLs was also concentrated in the 
personal, construction and tourism sectors (Figure 4). In many countries, NPL ratios in these sectors remained elevated after the crisis, consistent with the slow pace of economic recovery in much of the region. Persistently high NPLs also reflected banks' slow pace of restructuring, sale of NPLs, and write-offs, even after a gradual pickup in economic activity. In most economies, NPL ratios remain above their pre-crisis levels. In several countries, including Antigua and Barbuda, Belize, and Jamaica, NPL ratios have been falling steadily since 2012 toward their pre-crisis levels (Figure 1).

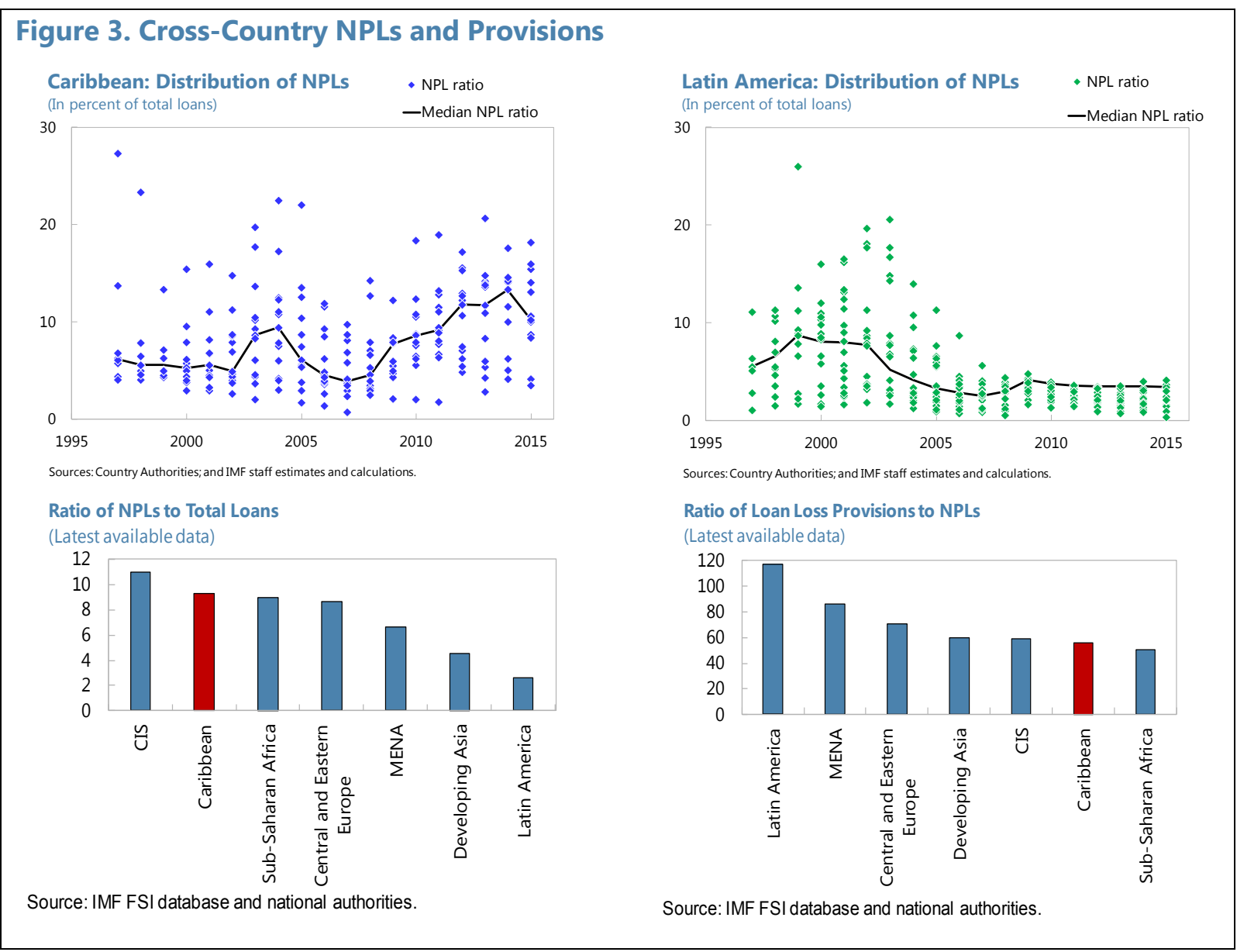




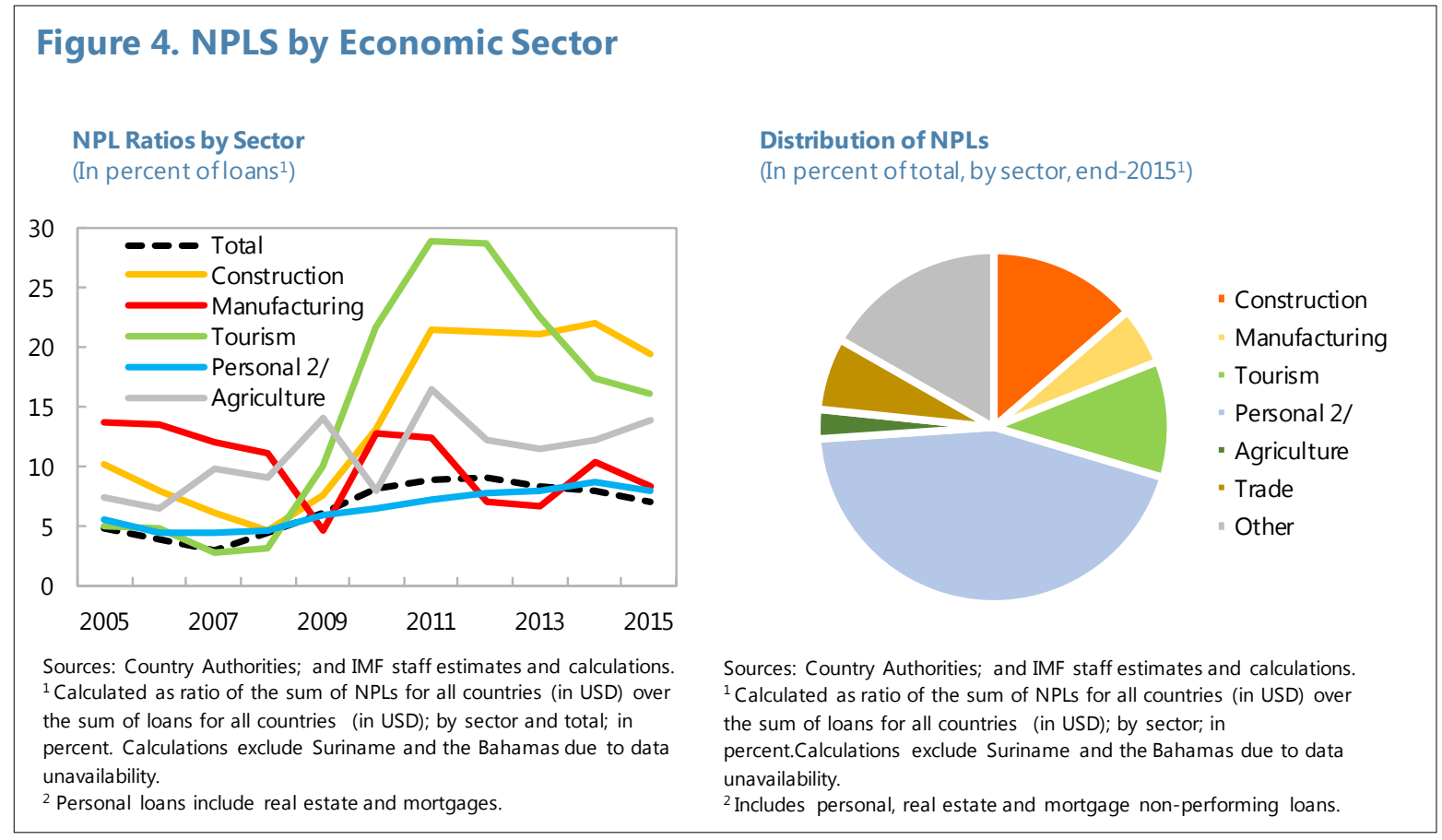

While remaining high, there is considerable heterogeneity in the ratio of NPLs across banks in the region. As of 2015, the NPL ratio varied from about 40 percent of total loans to close to zero. The distribution of NPLs has widened, with more banks experiencing higher NPL ratios after the crisis (Figure 5). Domestic banks have higher average NPL ratios than foreign-owned banks, but provisioning ratios, which were much lower in domestic banks before the crisis, are now about the same as foreign-owned banks' provisioning.
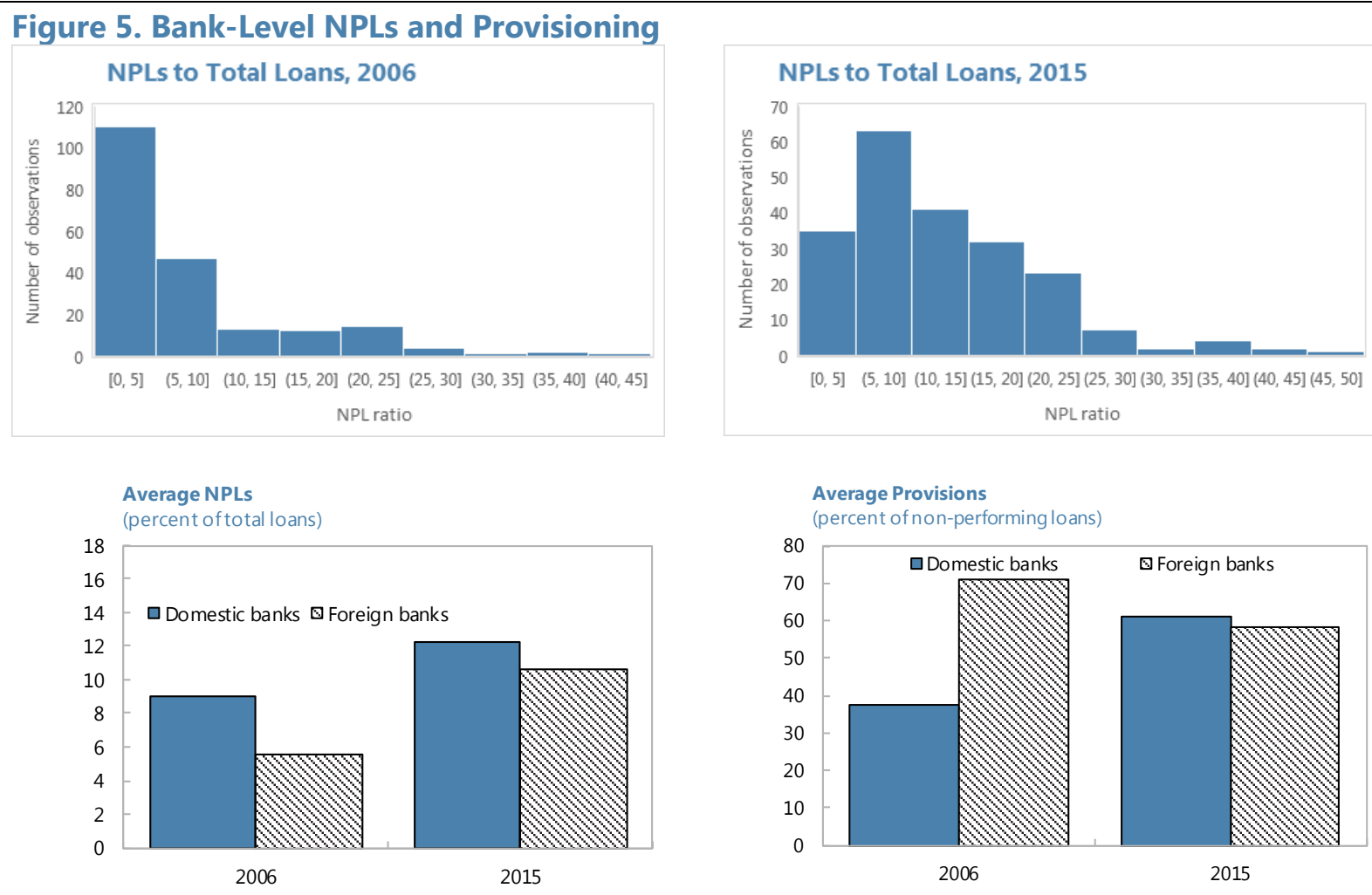

Sources: Country auhtorities and IMF staff calculations.

Sources: Country auhtorities and IMF staff calculations. 


\section{MaCRo-FinanCial IMPLICATIONS OF High NPLS}

High levels of NPLs affect bank lending and may result in adverse macro-financial feedback loops. High NPLs typically reduce the supply of credit, including by reducing bank profitability, tying up capital because of higher risk weights on impaired assets, and raising banks' funding costs because of lower expected revenue streams and investors' heightened risk perceptions (Aiyar 2015). Following the global financial crisis, Caribbean banks tightened their lending standards as they focused on cleaning up their balance sheets, reducing credit and downsizing and consolidating their operations to compensate for reduced profits (Annexes 1 and 2). Reduced credit supply, in turn, contributed to a weaker economic activity, with adverse implications for NPLs. Country-level data indicate that NPL ratios are negatively correlated with bank profitability and private sector credit growth, suggesting that banks with higher NPL ratios have lower profitability and lending (Figure 6). Private credit growth is positively correlated with economic activity, suggesting that high NPLs are associated with subdued growth and rising unemployment.

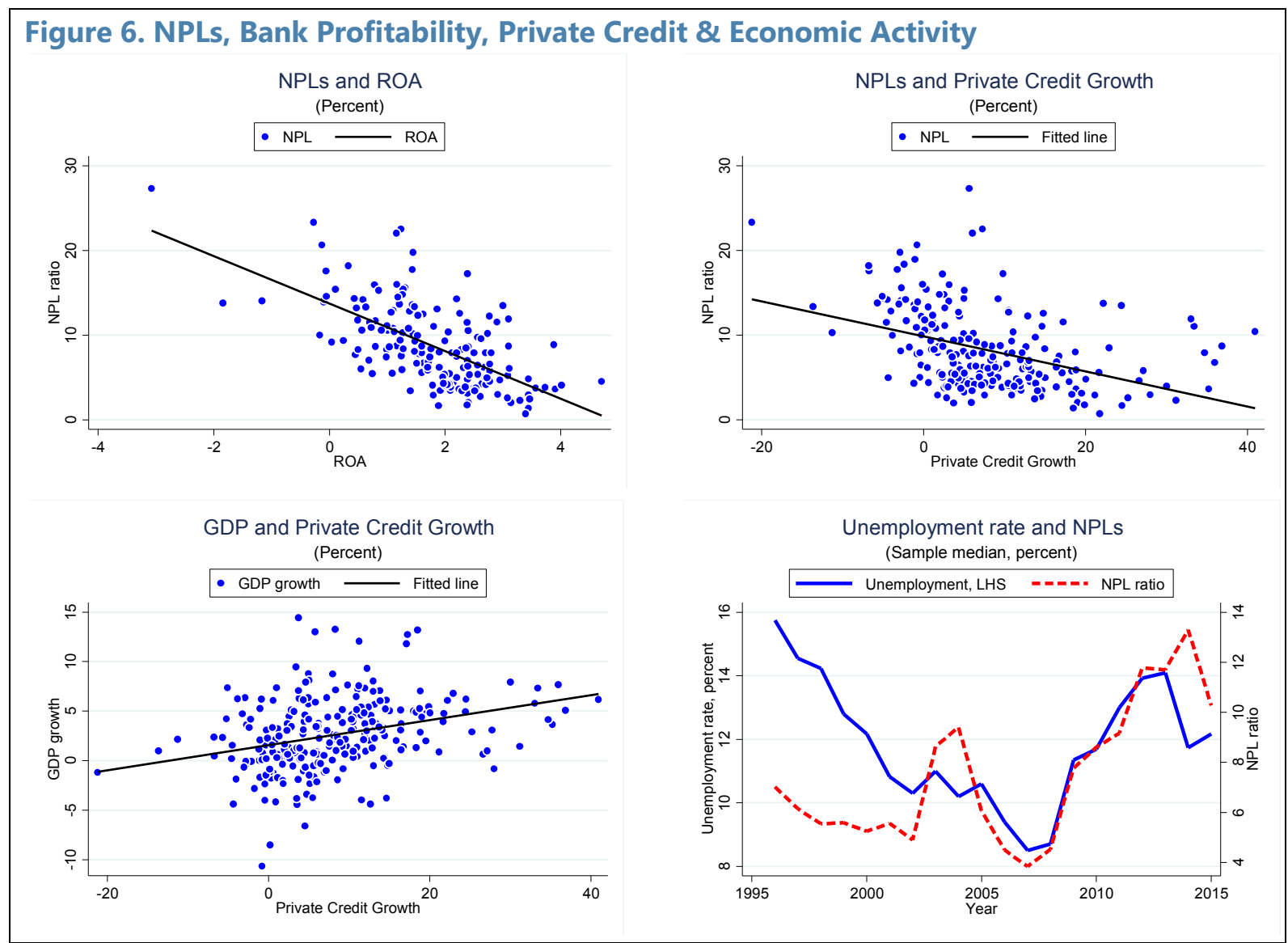

A. Analyzing Macro-Financial Linkages: Data and Methodology

A panel VAR model is estimated to assess feedback effects between asset quality in the banking sector and the real economy. The model treats all variables as endogenous, while allowing unobserved heterogeneity across countries (Abrigo and Love, 2015), and includes five endogenous variables (change in the ratio of NPLs to total loans, growth of credit to the private sector, change in the unemployment rate, real GDP growth, and consumer price inflation); a vector of exogenous variables (change in the U.S. unemployment rate, to capture 
the close linkages between the Caribbean and advanced economies, particularly the United States, and a dummy variable for natural disasters, a shock to which the region is highly susceptible); and country fixed effects:

$$
\begin{aligned}
& Y_{i t}=Y_{i t-1} A_{1}+Y_{i t-2} A_{2}+\cdots+Y_{i t-p+1} A_{p-1}+Y_{i t-p} A_{p}+X_{i t} B+u_{i}+e_{i t} \\
& \boldsymbol{Y}_{i t}=\left[\Delta n p l_{i, t}, \Delta \operatorname{credit}_{i, t}, \Delta U_{i, t}, \Delta G D P_{i, t}, \Delta C P I_{i, t}\right]
\end{aligned}
$$

where, $Y_{i, t}$ is a vector of five endogenous variables, $\Delta n p l_{i, t}$ denotes the change in the ratio of NPLs to total loans for the banking system in country $i$ in year $t, \Delta$ credit $_{i, t}$ denotes year-onyear growth of credit to the private sector in country $i$ in year $t, \Delta U_{i, t}$ denotes the change in unemployment rate in country $i$ in year $t, \Delta G D P_{i, t}$ denotes real GDP growth in country $i$ in year $t, \Delta C P I_{i, t}$ denotes average annual CPI inflation in percent, $X_{i, t}$ is a vector of exogenous covariates, $u_{i}$ and $e_{i t}$ are vectors of country-specific fixed effects and idiosyncratic errors, respectively. ${ }^{3}$ The approach allows examining the interactions among variables, including the duration and magnitude of the effect. Macro-financial feedback effects are assessed using impulse response functions, which illustrate the behavior of one variable in response to innovations in another variable, holding other shocks constant. ${ }^{4}$

The analysis is based on an unbalanced panel data set, covering the period of 1997 to 2015. Data largely originate from regional central banks, supplemented by World Bank World Development Indicators and series from the World Economic Outlook. Unit root tests indicate that all panel VAR variables are stationary of order I(0). Because the unemployment rate is unavailable for 5 out of 13 countries in the sample, the baseline model is estimated for 8 Caribbean economies, using an unbalanced panel of annual observations, with the major macroeconomic indicators unavailable at a higher frequency. ${ }^{5}$ A model excluding unemployment is also estimated for the full sample. To assess whether the strength of the feedback effects from the banking system to the real economy varies depending on the type of the economy, a distinction is also made for tourism-dependent economies and commodity exporters in the Caribbean (the latter including Guyana, Suriname, and Trinidad and

\footnotetext{
${ }^{3}$ To account for the correlation of fixed effects with the regressors due to the presence of lags of the dependent variable in the equation, the analysis uses a forward mean-differencing (Helmert procedure) to remove the mean of all forward future observations available for each country-year, which retains the orthogonality between the lagged regressors and the transformed variables. Estimates are produced using lagged regressors as instruments and estimate the coefficient by Generalized Method of Moments (GMM) methodology (Klein, 2013). 300 Monte Carlo simulations are used to generate the confidence intervals. Impulse responses are orthogonalized. Orthogonal shocks are identified using the Cholesky decomposition.

${ }^{4}$ Variables that enter equation (1) first are assumed more exogenous than the variables that appear later in the model, suggesting that they impact the subsequent variables both contemporaneously and with a lag; whereas the variables toward the end of the equation are assumed to affect the first ones only with a lag (Love, 2013). In the baseline specification, NPLs appear first in the ordering, followed by credit growth, change in the unemployment rate, real GDP growth, and CPI inflation, reflecting our assumption that unemployment, GDP growth, and inflation, affect delinquent loans only with a lag, while NPLs have a contemporaneous effect on economic activity, largely through credit. Results are broadly robust to alternative orderings of the variables.

5 The full sample includes 242 observations from the following countries: Antigua and Barbuda, The Bahamas, Barbados, Belize, Dominica, Grenada, Guyana, Jamaica, St. Kitts and Nevis, St. Lucia, St. Vincent and the Grenadines, Suriname, Trinidad and Tobago. Time series unemployment data are unavailable for Antigua and Barbuda, Dominica, Grenada, St. Kitts and Nevis, and St. Vincent and the Grenadines.
} 
Tobago). Results are broadly robust to alternative specifications. ${ }^{6}$ Simple correlations of key macro-financial variables indicate that the NPL ratio is negatively correlated with inflation, foreign direct investment, real GDP, and credit growth, and positively correlated with the unemployment rate (Table 1).

\begin{tabular}{|c|c|c|c|c|c|c|c|}
\hline \multicolumn{8}{|c|}{$\begin{array}{l}\text { Table 1. Correlation Across Macro-Financial Variables } \\
\text { (Annual frequency) }\end{array}$} \\
\hline & & NPL & Loan & FDI & U & GDP & CPI \\
\hline NPL ratio change & NPL & 1 & & & & & \\
\hline Loan growth & Loan & $-0.1377^{*}$ & 1 & & & & \\
\hline FDI growth & FDI & -0.0057 & $-0.1317^{*}$ & 1 & & & \\
\hline Change in unemployment rate & $U$ & $0.2895^{\star}$ & $-0.2525^{\star}$ & -0.1113 & 1 & & \\
\hline Real GDP growth & GDP & $-0.1225^{*}$ & $0.2524^{\star}$ & 0.0159 & $-0.3779^{*}$ & 1 & \\
\hline Inflation & CPI & -0.0309 & $0.4015^{*}$ & -0.0152 & 0.0101 & $-0.1289^{*}$ & 1 \\
\hline
\end{tabular}

\section{B. Results}

The analysis points to the presence of strong macro-financial links in the Caribbean economies, which holds for both tourism and commodity-dependent economies (Annex 3, Figures A3.1-A3.3). A deterioration in bank asset quality, or a shock to the NPL ratio, has a statistically significant impact on private sector credit growth, economic activity (Figure 7), and unemployment. Negative implications for credit growth are persistent, lasting up to five years. The persistence of credit cycles also suggests that a shock to credit growth continues for several years. Lower private credit growth, in turn, reduces economic activity and results in an increase in unemployment.

Conversely, macroeconomic performance also has a significant effect on asset quality: stronger macroeconomic environment improves borrowers' debt servicing capacity and leads to a statistically significant decline in the NPL ratio (Figure 7), largely through higher employment and income gains: a positive shock to real GDP growth stimulate lending, and eventually lead to an increase in NPLs, if accompanied by banks' loosening their underwriting standards. This effect, however, is offset by an improved debt servicing capacity, as higher GDP lowers the unemployment rate and leads to an overall decline in NPLs. The baseline model suggests that one percentage point increase in real GDP growth, holding other factors constant, leads to a 0.12 percentage point decline in the NPL ratio.

\footnotetext{
${ }^{6}$ Robustness checks also include alternative model specifications that add FDI to account for strong linkages between FDI inflows and economic performance in the Caribbean, as well as industry-specific models using sectoral NPLs and credit growth.
} 


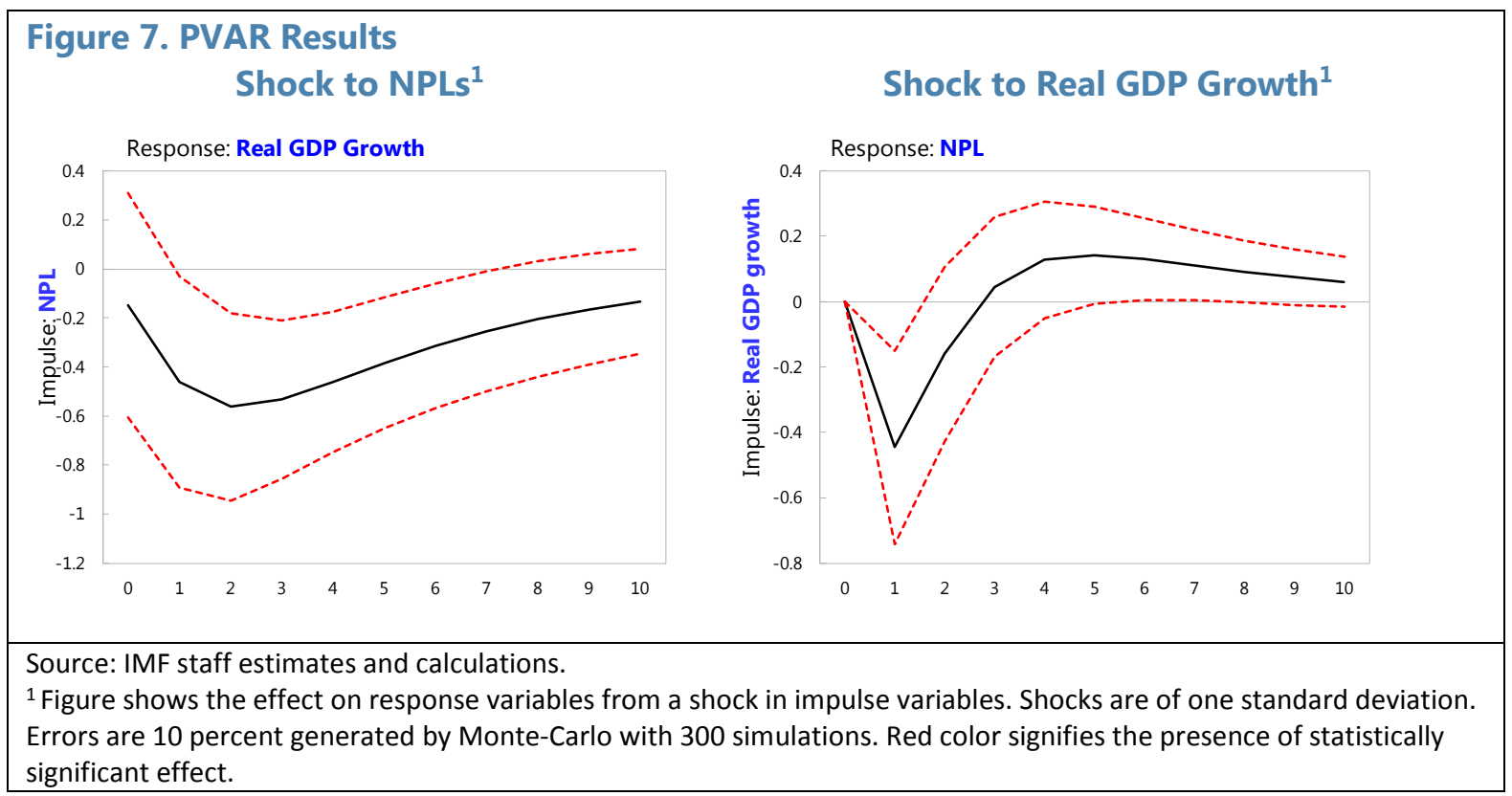

Panel VAR variance decompositions (Annex 3, Figure A3.4) indicate that over a five-year horizon, about 22 percent of the variance in the NPL ratios in the productive sectors (including construction, tourism, agriculture, and manufacturing) is driven by shocks to real GDP growth, suggesting that economic growth is an important determinant of asset quality. Meanwhile, the impact of the NPL ratio on growth is smaller, with shocks to the NPL ratio explaining about 7 percent of the variance in real GDP growth, and about 9 percent of the variance in the unemployment rate.

\section{DETERMINANTS OF NPLS}

\section{A. Data and Methodology}

Country-level and bank-level panel regressions are used to systematically assess the determinants of NPLs in the Caribbean. A dynamic panel regression is estimated, first to analyze the determinants of NPLs at an annual frequency, focusing on macroeconomic determinants of NPLs, and subsequently to analyze the bank-specific determinants of NPLs at a higher frequency. The basic dynamic panel regression specification for the annual country-level regressions is given by:

$$
N P L s_{j, t}=\alpha+\beta_{1} \sum_{k} N P L s_{j ; t-k}+\beta_{2} \sum_{k} \text { Global }_{t-k}+\beta_{3} \sum_{k} \operatorname{Country}_{j, t-k}+u_{j}+\varepsilon_{j, t},(2)
$$

where, $N P L s_{j, t}$ denotes the logit transformation of the NPL ratio for country $j$ at time $t .{ }^{7}$ The dependent variable is explained by its lag $\left(N P L s_{j, t-\mathrm{k}}\right)$, global and country-specific macroeconomic variables ((Global $)$ and (Country ( $\left._{j, t}\right)$, respectively, and country fixed effects $\left(u_{j}\right)$, with $k$ showing the number of annual lags. The model is estimated with an unbalanced

\footnotetext{
${ }^{7}$ This transformation follows the literature of credit risk and ensures that all predicted values are non-negative and are between 0 and 1 .
} 
panel of 13 Caribbean countries. ${ }^{8}$ Interaction terms between NPL determinants in the benchmark model (2) and dummy variables for tourism- and commodity-dependent economies are also included to assess the extent to which the determinants of NPLs differ across the two groups of countries in the Caribbean.

The same baseline model is estimated using bank-level data for bank $i$ in country $j$ at time $t$, with quarterly data in an unbalanced panel of 71 banks across 13 Caribbean countries. In addition to the variables considered in equation (2), the bank-level model includes detailed bank-level $\left(\right.$ Bank $\left._{i, j, t}\right)$ variables capturing credit risk (including profitability, capital adequacy, measures of efficiency (e.g. the expense-to-assets ratio), bank size, and credit concentration), as well as bank-level fixed effects.

$$
\begin{aligned}
& N P L s_{i, j . t}=\alpha+\beta_{1} \sum_{k} N P L s_{i, j . t-k}+\beta_{2} \sum_{k} \text { Global }_{t-k}+ \\
& \beta_{3} \sum_{k} \text { Country }_{j, t-k}+\beta_{4} \sum_{k} \text { Bank }_{i, j, t-k}+\beta_{5} \text { Country }_{i}+u_{i}+\varepsilon_{i, j, t}
\end{aligned}
$$

where $u_{i}$ are now bank-fixed effects and country-specific fixed effects are controlled for by including country $\left(\right.$ Country $\left.D_{i}\right)$ dummy variables. We further build on equation (3) by assessing the impact of bank ownership structure on NPLs by interacting a foreign bank dummy variable with all other determinants in the model.

All models are estimated with dynamic panel regression techniques, using the system generalized method of moments (SGMM) to address dynamic panel bias (Nickell 1981) and endogeneity. ${ }^{9}$ The instrument set is restricted to avoid overfitting bias and only the first and second appropriate lag of each explanatory variable are used. ${ }^{10}$ The model specifications treat all global and country-specific variables, except for country-specific economic growth, as strictly exogenous, and all bank-specific variables and country-specific economic growth as endogenous, instrumented with their lagged values. Robustness checks confirm that results are robust to different instrument sets and generally confirm the baseline results. ${ }^{11}$

An important caveat, as with other cross-country empirical studies of the determinants of NPLs, is that the classification of NPLs may not be fully consistent across countries due to differences in accounting approaches and regulations. This problem is partially mitigated by controlling for unobserved fixed effects, to the extent that the country-specific approaches to classifying NPLs have remained relatively constant over-time. Differences in the treatment of restructured and ever-greened loans in NPLs may also affect the results, as well as other institutional factors, such as availability and coverage of credit bureaus and credit rating agencies, efficiency of insolvency and debt enforcement frameworks including functioning of implementing institutions such as courts, and quality of bank supervision and financial regulation. The lack of time series data comparable across countries makes it difficult to include these factors in the empirical analysis, but survey responses from the region's banks

\footnotetext{
${ }^{8}$ These include six independent members of the ECCU, The Bahamas, Barbados, Belize, Guyana, Jamaica, Suriname, and Trinidad and Tobago. For most countries, data are available from about 2000, with the number of observations of the NPL ratio ranging from 14 to 26 within the unbalanced panel.

${ }^{9}$ For the SGMM, see Arellano and Bover (1995) and Blundell and Bond (1998).

${ }^{10}$ See Arellano and Bond (1998) and Holtz-Eakin, Newey, and Rosen (1988) for details.

11 The validity of the instrument set is tested by the Hansen test of over-identifying restrictions. The analysis also tests for second-order serial correlation in the first differenced error term.
} 
and country authorities, discussed in detail in Section V, show that many of these factors have been important determinants of high NPLs in the region and the slow pace of their resolution.

\section{B. Results}

Country-level panel regressions support the earlier finding that economic activity is an important determinant of banks' asset quality. Asset quality deteriorates as a function of low real GDP growth, both at home and in advanced economies (Table 2). Spillovers from global macroeconomic developments are particularly strong, with the coefficient on real GDP growth in advanced economies larger and statistically more significant than that on domestic growth, consistent with the high degree of openness of economies in the region. Asset quality also deteriorates as a function of higher lending rates that reduce borrowers' capacity to service debt. An appreciation of the real effective exchange rate, which would similarly reduce borrowers' capacity to service their foreign currency loans, does not appear to be a significant determinant of NPLs. Reduced credit growth also results in a higher NPL ratio, suggesting that NPLs fall at a slower rate than banks' deleveraging. A dummy variable included to capture the potential impact of natural disasters on NPLs does not have a significant coefficient, but this result may reflect the relatively short period considered in the regression or its impact may have been captured by other variables in the regression. Finally, estimating the regression separately for the periods before and after 2009 suggests that the global financial crisis explains much of the variation in asset quality, capturing the impact of macroeconomic developments in the post-crisis period.

The macroeconomic determinants of NPLs are broadly comparable for tourism-dependent and commodity exporting countries. That is, macroeconomic developments affect NPLs in tourism-dependent and commodity-exporting countries in a similar manner (Annex 4, Table A4.1). Augmenting the baseline model with growth in tourism arrivals and interacting that variable with a dummy for tourism-dependence suggests that stronger tourism arrivals for tourism-dependent economies help to improve asset quality. On the other hand, augmenting the baseline model with oil price growth and interacting it with a dummy variable for commodity exporters suggest that oil prices are not a significant determinant of asset quality for either tourism-dependent or oil-exporting economies in the region.

The bank-level analyses show that both macroeconomic and bank-specific factors are important determinants of NPLs (Annex 4, Table A4.2 and Table 3). NPLs are persistent (suggested by the coefficient on lagged NPLs), pointing to a slow pace of resolving problem loans. Deterioration in advanced economy growth worsens asset quality. Tourism arrivals, by contrast, are statistically insignificant, with their effect likely captured by advanced economy growth, which is an important determinant of tourism arrivals to the region. Bank-specific factors are also important determinants of asset quality. More profitable, more capitalized, and more efficient banks (as measured by expense-to-asset and income-to-expense ratios) tend to have better asset quality. Exposure to credit risk associated with higher lending to the household sector and higher foreign currency lending does not seem to be a significant determinant of NPLs at the bank level. The results also suggest that asset quality is not affected by whether banks are foreign or domestically owned (assessed by interacting a foreign bank dummy with all other determinants in the benchmark model) (Annex 4, Tables 
A4.3 and A4.4). The significant dispersion in NPL ratios across banks may explain this result. $^{12}$

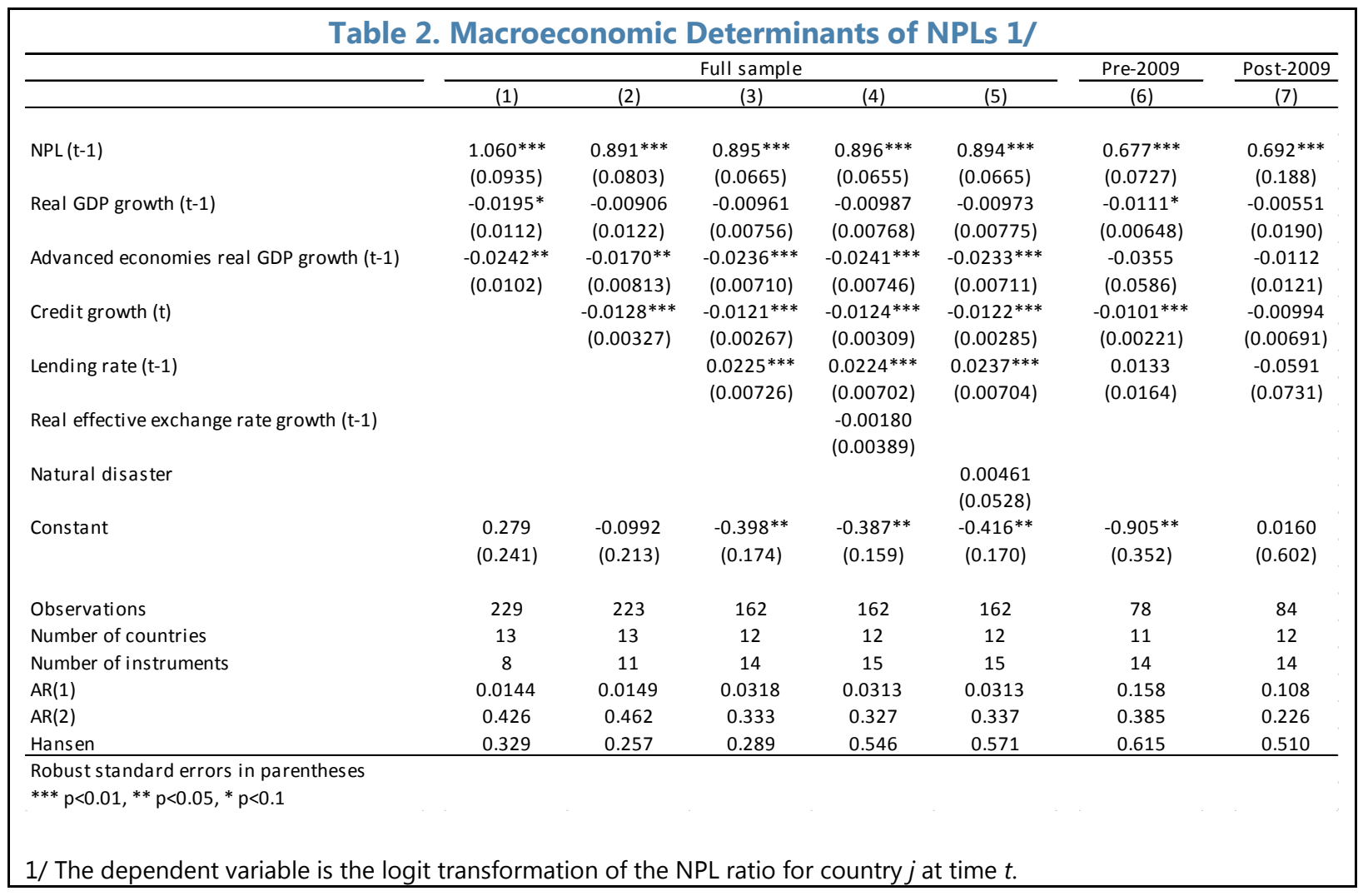

\section{OBSTACLES TO NPL RESOLUTION}

Although the high level of NPLs in the Caribbean has been, in large part, a legacy of the global financial crisis, their persistence owes much to the weak economic recovery in the region, as well as to structural obstacles to resolution. The pace of loan restructuring, NPL sales, and write-offs has been slow, leaving large amounts of impaired assets on bank balance sheets. Results from a survey of country authorities and banks operating in the region highlight some common elements undermining NPL resolution. This section summarizes the results of the survey, which asked banks and national and regional authorities to (1) identify the key obstacles to NPL resolution, (2) provide detailed information on structural impediments grouped into five broad areas: supervisory and prudential, insolvency and debt enforcement, informational systems, market for distressed debt, and tax regime, and (3)

\footnotetext{
${ }^{12}$ For most ECCU countries, Belize, and Suriname, domestic banks have higher NPL ratios compared with foreign banks - primarily subsidiaries and branches of international banks that benefit from stronger risk management practices and greater capacity to dispose of /write-off impaired assets. In The Bahamas, Grenada, St. Vincent and the Grenadines, and Trinidad and Tobago, the ratio is higher for foreign-owned banks.
} 
Table 3. Bank-Level Determinants of NPLs: Bank Performance

\begin{tabular}{|c|c|c|c|c|c|c|c|c|c|c|c|c|}
\hline \multirow{2}{*}{ 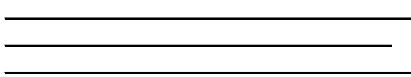 } & \multirow{2}{*}{$\begin{array}{l}\text { Baseline } \\
(1) \\
\end{array}$} & \multicolumn{3}{|c|}{ Profitability } & \multirow{2}{*}{$\frac{\frac{\text { Capital adeqaucy }}{(5)}}{\text { (5) }}$} & \multicolumn{5}{|c|}{ Bank efficiency } & \multicolumn{2}{|c|}{ Credit concentration } \\
\hline & & (2) & (3) & (4) & & (6) & (7) & $(8)$ & (9) & $(10)$ & $(11)$ & $(12)$ \\
\hline$N P L(t-1)$ & $0.631 * * *$ & $0.624 * * *$ & $0.608^{* * *}$ & $0.614 * * *$ & $0.591 * * *$ & $0.591^{* * *}$ & $0.789 * * *$ & $0.783 * * *$ & $0.789 * * *$ & $0.579 * * *$ & $0.641 * *$ & $0.733^{* * *}$ \\
\hline & $(0.0630)$ & $(0.0685)$ & $(0.0723)$ & $(0.0800)$ & $(0.0804)$ & $(0.0772)$ & $(0.0940)$ & $(0.0803)$ & $(0.0873)$ & $(0.0935)$ & $(0.0671)$ & $(0.0894)$ \\
\hline NPL (t-2) & $\begin{array}{l}0.190^{* * *} \\
(0.0569)\end{array}$ & $\begin{array}{l}0.151 * * \\
(0.0511)\end{array}$ & $\begin{array}{l}0.144 * * * \\
(0.0525)\end{array}$ & $\begin{array}{l}0.128 * * \\
(0.0637)\end{array}$ & $\begin{array}{l}0.144 * * \\
(0.0535)\end{array}$ & $\begin{array}{l}0.124 * * \\
(0.0559)\end{array}$ & $\begin{array}{c}0.0284 \\
(0.0669)\end{array}$ & $\begin{array}{c}0.0351 \\
(0.0631)\end{array}$ & $\begin{array}{c}0.0329 \\
(0.0649)\end{array}$ & $\begin{array}{l}0.146 * * \\
(0.0545)\end{array}$ & $\begin{array}{l}0.146 * * \\
(0.0537)\end{array}$ & $\begin{array}{l}0.183 * * \\
(0.0537)\end{array}$ \\
\hline Advanced economies real GDP growth $(\mathrm{t}-1)$ & $\begin{array}{l}-0.00704^{* *} \\
(0.00330)\end{array}$ & $\begin{array}{l}-0.00597^{*} \\
(0.00309)\end{array}$ & $\begin{array}{l}-0.00674^{* *} \\
(0.00337)\end{array}$ & $\begin{array}{l}-0.00480 \\
(0.00346)\end{array}$ & $\begin{array}{l}-0.00533 \\
(0.00351)\end{array}$ & $\begin{array}{l}-0.00569 \\
(0.00380)\end{array}$ & $\begin{array}{l}-0.00285 \\
(0.00407)\end{array}$ & $\begin{array}{c}-0.00286 \\
(0.00307)\end{array}$ & $\begin{array}{c}-0.00342 \\
(0.00344)\end{array}$ & $\begin{array}{c}-0.00783 \\
(0.00602)\end{array}$ & $\begin{array}{l}-0.00473 \\
(0.00337)\end{array}$ & $\begin{array}{c}-0.0119 * * * \\
(0.00415)\end{array}$ \\
\hline Credit growth (t) & $\begin{array}{c}-0.00452^{* * *} \\
(0.00100)\end{array}$ & $\begin{array}{c}-0.00429 * * * \\
(0.000903)\end{array}$ & $\begin{array}{c}-0.00417^{* * *} \\
(0.000933)\end{array}$ & $\begin{array}{l}-0.00405^{* *} \\
(0.00180)\end{array}$ & $\begin{array}{c}-0.00376^{* * *} \\
(0.00100)\end{array}$ & $\begin{array}{c}-0.00496 * * * \\
(0.00117)\end{array}$ & $\begin{array}{l}-0.00351^{* *} \\
(0.00142)\end{array}$ & $\begin{array}{c}-0.00353^{* * *} \\
(0.00129)\end{array}$ & $\begin{array}{l}-0.00349 * * \\
(0.00136)\end{array}$ & $\begin{array}{c}-0.00461 * * * \\
(0.00144)\end{array}$ & $\begin{array}{c}-0.00478^{* * *} \\
(0.00106)\end{array}$ & $\begin{array}{l}-0.00284 * * * \\
(0.000961)\end{array}$ \\
\hline Return on assets ( $t$ ) & & $\begin{array}{l}-0.0122^{*} \\
(0.00641)\end{array}$ & & & $\begin{array}{l}-0.0144^{*} \\
(0.00756)\end{array}$ & $\begin{array}{l}-0.0150^{*} \\
(0.00785)\end{array}$ & $\begin{array}{l}-0.00278 \\
(0.00636)\end{array}$ & $\begin{array}{l}0.000681 \\
(0.00429)\end{array}$ & $\begin{array}{r}-0.000286 \\
(0.00457)\end{array}$ & $\begin{array}{l}-0.0157^{*} \\
(0.00833)\end{array}$ & $\begin{array}{c}-0.0106 \\
(0.00866)\end{array}$ & $\begin{array}{l}-0.0119 \\
(0.00749)\end{array}$ \\
\hline Return on equity ( $t$ ) & & & $\begin{array}{l}-0.000291 \\
(0.000219)\end{array}$ & & & & & & & & & \\
\hline Net interest margin $(\mathrm{t})$ & & & & $\begin{array}{l}-0.0810^{*} \\
(0.0428)\end{array}$ & & & & & & & & \\
\hline Capital Adequacy Ratio (t) & & & & & $\begin{array}{l}-0.00582 * \\
(0.00331)\end{array}$ & $\begin{array}{l}-0.00396 \\
(0.00394)\end{array}$ & $\begin{array}{c}0.00779 \\
(0.00874)\end{array}$ & $\begin{array}{c}0.00431 \\
(0.00686)\end{array}$ & $\begin{array}{c}0.00786 \\
(0.00772)\end{array}$ & $\begin{array}{c}-0.00530 \\
(0.00359)\end{array}$ & & \\
\hline Loan-to-deposit ratio (t-1) & & & & & & $\begin{array}{c}-0.00618^{* *} \\
(0.00307)\end{array}$ & & & & & & \\
\hline Expense-to-assets ratio (t-1) & & & & & & & $\begin{array}{l}0.0906^{* *} \\
(0.0376)\end{array}$ & & $\begin{array}{c}0.0263 \\
(0.0512)\end{array}$ & & & \\
\hline Income-to-expenses ratio (t) & & & & & & & & $\begin{array}{l}-0.202^{* * *} \\
(0.0697)\end{array}$ & $\begin{array}{l}-0.181^{*} \\
(0.0925)\end{array}$ & & & \\
\hline Total assets $(\ln )(\mathrm{t})$ & & & & & & & & & & $\begin{array}{l}0.0459 \\
(0.105)\end{array}$ & & \\
\hline Loans to households (in percent of total) (t) & & & & & & & & & & & $\begin{array}{l}-0.00341 \\
(0.00304)\end{array}$ & \\
\hline Foreign currency loans (in percent of total) (t) & & & & & & & & & & & & $\begin{array}{r}-2.31 \mathrm{e}-06 \\
(3.56 \mathrm{e}-06)\end{array}$ \\
\hline Constant & $\begin{array}{l}-0.427 \\
(0.273)\end{array}$ & $\begin{array}{l}-0.533^{* *} \\
(0.269)\end{array}$ & $\begin{array}{c}-0.598^{* *} \\
(0.285)\end{array}$ & $\begin{array}{l}-0.545 \\
(0.345)\end{array}$ & $\begin{array}{l}-0.577^{*} \\
(0.304)\end{array}$ & $\begin{array}{l}-0.195 \\
(0.183)\end{array}$ & $\begin{array}{c}-0.746^{* *} \\
(0.352)\end{array}$ & $\begin{array}{l}-0.238 \\
(0.181)\end{array}$ & $\begin{array}{l}-0.374 \\
(0.230)\end{array}$ & $\begin{array}{l}-1.133 \\
(1.508)\end{array}$ & $\begin{array}{l}-0.360 \\
(0.303)\end{array}$ & $\begin{array}{l}-0.145 \\
(0.210)\end{array}$ \\
\hline Observations & 3,709 & 3,508 & 3,363 & 3,286 & 3,063 & 3,063 & 766 & 766 & 766 & 3,063 & 3,283 & 948 \\
\hline Number of banks & 71 & 71 & 66 & 62 & 62 & 62 & 22 & 22 & 22 & 62 & 62 & 28 \\
\hline Number of instruments & 10 & 13 & 13 & 10 & 16 & 19 & 19 & 19 & 22 & 19 & 16 & 16 \\
\hline $\operatorname{AR}(1)$ & $3.58 \mathrm{e}-07$ & $5.41 \mathrm{e}-07$ & $7.60 \mathrm{e}-07$ & $2.05 \mathrm{e}-06$ & $2.79 \mathrm{e}-06$ & $2.35 \mathrm{e}-06$ & 0.00985 & 0.00917 & 0.00914 & $2.92 \mathrm{e}-06$ & $1.47 \mathrm{e}-06$ & 0.00105 \\
\hline $\operatorname{AR}(2)$ & 0.437 & 0.870 & 0.687 & 0.749 & 0.634 & 0.232 & 0.771 & 0.729 & 0.771 & 0.751 & 0.921 & 0.551 \\
\hline Hansen & 0.485 & 0.446 & 0.756 & 0.520 & 0.624 & 0.484 & 0.836 & 0.564 & 0.460 & 0.650 & 0.282 & 0.913 \\
\hline
\end{tabular}


identify the key measures undertaken by the authorities and banks in recent years toward resolution of NPLs. ${ }^{13}$ Responses were received from the authorities of the Eastern Caribbean Central Bank, The Bahamas, Barbados, Belize, Guyana, Jamaica, Montserrat, St. Kitts and Nevis, Suriname, and Trinidad and Tobago, and 39 banks representing 40 percent of all banks in the region. Annex 1 provides a more detailed discussion of the factors underlying the accumulation and slow resolution of NPLs for selected Caribbean countries, and Annex 2 summarizes key measures undertaken by the authorities and banks in recent years and Annex 4 provides detailed survey responses.

Survey responses from the authorities and banks highlight macroeconomic conditions, deficiencies in the legal process, and difficulties with collateral as the key obstacles to NPL resolution (Figure 8). Most banks identified macroeconomic conditions, such as slow

Figure 8. Top Obstacles to NPL Resolution in the Caribbean

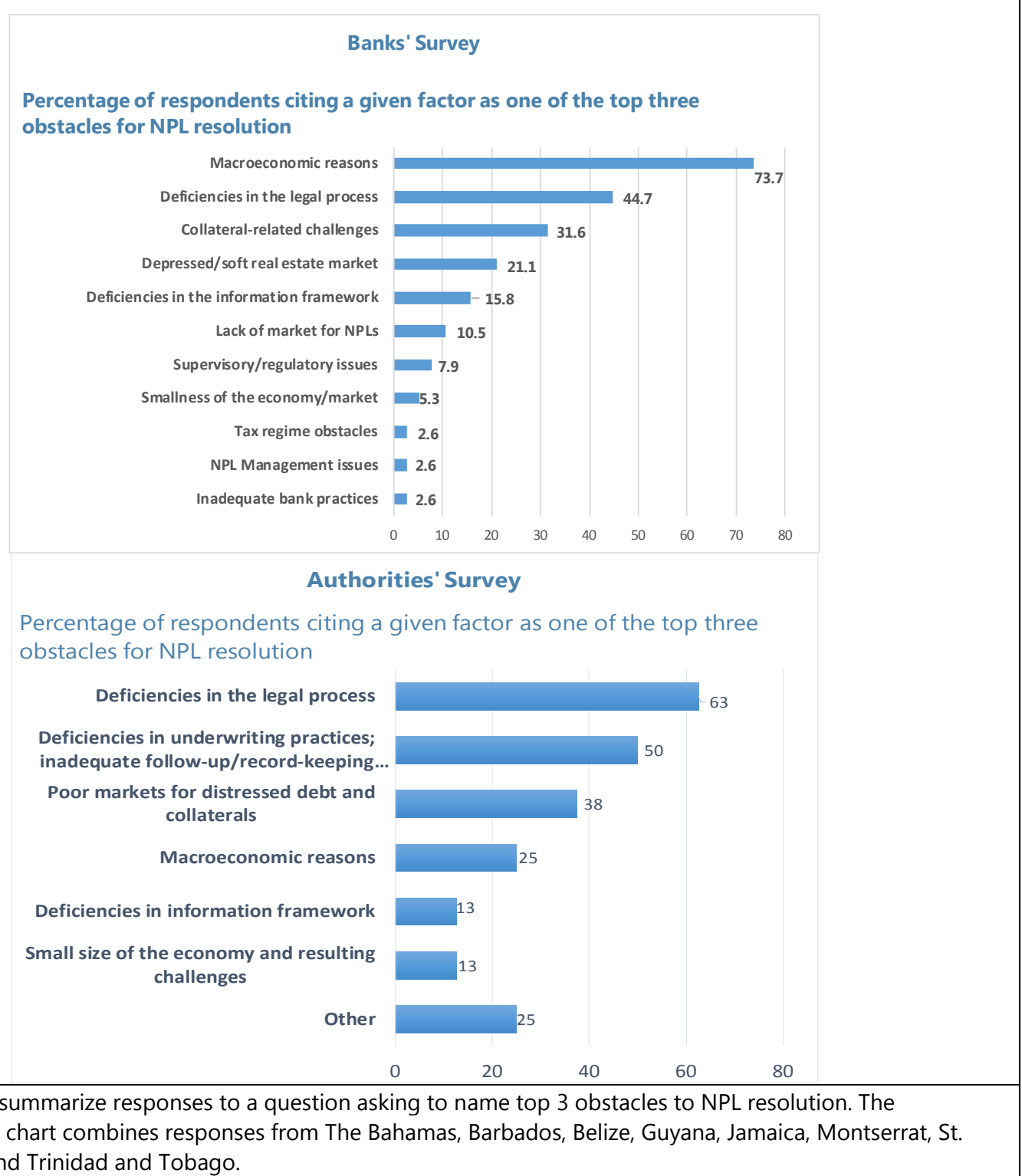




\begin{tabular}{|c|c|c|c|c|c|c|c|c|c|}
\hline & \multicolumn{8}{|c|}{ Countries } & \multirow[b]{2}{*}{ Average } \\
\hline & 1 & 2 & 3 & 4 & 5 & 6 & 7 & 8 & \\
\hline 1. Market for NPLs & 3.0 & 3.0 & 2.0 & 2.0 & 3.0 & 2.0 & 3.0 & 1.3 & 2.4 \\
\hline 2. Information obstacles & 2.4 & 2.1 & 2.2 & 2.3 & 1.9 & 1.9 & 1.5 & 1.4 & 2.0 \\
\hline 2.1 Public registers & 2.0 & 2.2 & 2.2 & 2.2 & 1.9 & 1.9 & 1.6 & 1.5 & 1.9 \\
\hline 2.2 Consumer and data protection & 2.8 & 2.0 & 2.1 & 2.4 & 2.0 & 2.0 & 1.3 & 1.4 & 2.0 \\
\hline 3. Insolvency and debt enforcement regimes & 2.8 & 2.0 & 2.7 & 2.0 & 1.3 & 1.7 & 1.1 & 1.5 & 1.9 \\
\hline 3.1 Corporate Insolvency and debt restructuring regime & 2.5 & 1.7 & 2.0 & 1.6 & 1.4 & 1.6 & 1.0 & 1.9 & 1.7 \\
\hline 3.2 Household debt resolution regime & $\ldots$ & 1.2 & 3.0 & 1.8 & 1.4 & 1.4 & 1.1 & 1.1 & 1.6 \\
\hline 3.3 Judicial system & 3.0 & 3.0 & 3.0 & 2.4 & 1.1 & 2.0 & 1.3 & 1.4 & 2.2 \\
\hline 4. Prudential/supervisory regime & 1.7 & 2.0 & 1.6 & 1.5 & 1.8 & 1.9 & 1.8 & 1.5 & 1.7 \\
\hline 4.1 NPL management issues & 1.8 & 2.1 & 1.7 & 1.9 & 1.9 & 2.1 & 2.1 & 1.9 & 1.9 \\
\hline 4.2 Collateral-related issues & 2.0 & 3.0 & 2.0 & 1.5 & 2.6 & 2.0 & 2.0 & 1.0 & 2.0 \\
\hline 4.3 Bank capitalization & 1.0 & 1.2 & 1.0 & 1.0 & 1.3 & 2.0 & 1.0 & 1.4 & 1.2 \\
\hline 4.4 Supervision & 2.0 & 1.9 & 1.8 & 1.7 & 1.6 & 1.6 & 2.1 & 1.9 & 1.8 \\
\hline 5. Taxation & $\ldots$ & 1.0 & 1.0 & 1.6 & 1.1 & 1.0 & 1.0 & 1.8 & 1.2 \\
\hline \multirow[t]{4}{*}{ Overall obstacle level } & 2.5 & 2.0 & 1.9 & 1.9 & 1.8 & 1.7 & 1.7 & 1.5 & 1.9 \\
\hline & \multirow[t]{3}{*}{ Coding: } & $\leq 1.5$ & \multirow{3}{*}{\multicolumn{3}{|c|}{$\begin{array}{l}\text { No (or low) concern; } \\
\text { Medium concern } \\
\text { Medium to High concern }\end{array}$}} & \multirow{3}{*}{\multicolumn{3}{|c|}{... Missing respon }} & \\
\hline & & $>1.5$ & & & & & & & \\
\hline & & $>2$ & & & & & & & \\
\hline \multicolumn{10}{|c|}{$\begin{array}{l}\text { Source: IMF staff survey of national authorities and banks. } \\
\text { Notes: The heat map shows maximum scores from country and bank surveys. The institutional obstacle scores are } \\
\text { compiled from individual responses to these surveys. The surveys asked the respondents to indicate their level of } \\
\text { concern regarding specific obstacles within five broad areas (such as NPL markets, information obstacles, etc.), and } \\
\text { provide information regarding these areas. Banks' responses within the same jurisdictions were aggregated by } \\
\text { averaging. The overall obstacle level is a simple average of obstacles scores in each of the five areas. Values } 2.0 \\
\text { appearing in a red box are marginally higher than } 2 \text {. }\end{array}$} \\
\hline
\end{tabular}

economic growth, high unemployment, and loss of clients' incomes, as among the most severe obstacles to resolving NPLs. Many banks also pointed to deficiencies in the legal process (e.g., costly and protracted insolvency procedures, or the absence of specialized courts or judges), difficulties in valuing and realizing collateral, and depressed real estate markets as major obstacles. The authorities highlighted deficiencies in the legal process and in banks' underwriting and monitoring practices and inability or limited financial capacity in certain banks to recognize loan impairment and provision against it. Poor markets for distressed debt and collateral and macroeconomic factors were also highlighted as top obstacles. 
Country-by-country survey responses highlight several key areas of concern in resolving NPLs. Among these, survey respondents ranked the absence of a market for distressed assets as the most challenging area for NPL resolution across the Caribbean (Figure 9). As in many European countries with high NPLs (Aiyar and others 2015), the market for trading distressed assets is largely nonexistent in the Caribbean despite the absence of explicit restrictions (Figure 10). The survey responses also suggest concerns about gaps in the information framework, deficiencies in insolvency and debt-enforcement regimes (including the legal system, institutional weaknesses, and collateral enforcement related challenges), and weaknesses in prudential and supervisory frameworks. The tax systems in the Caribbean were perceived as posing less concern than other broad areas. Many elements are common across countries; however, detailed responses show significant variation across countries and banks.

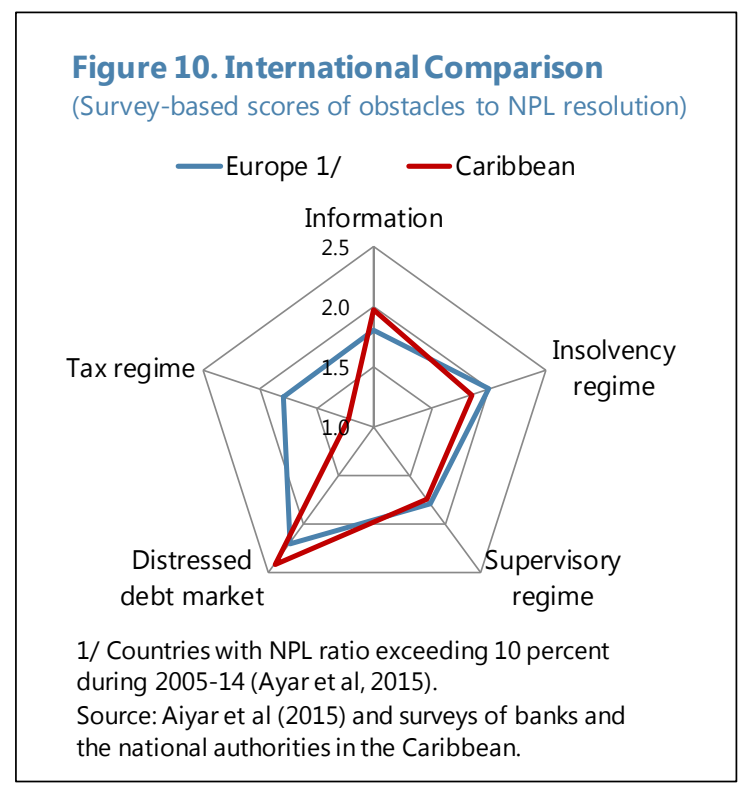

\section{A. Prudential and Supervisory Framework and NPL Management}

Strong supervision and conservative bank practices for loss recognition and provisioning increase incentives to address NPLs in a timely manner. Supervisory authorities in the region generally pay close attention to problem loans, tightening regulations in recent years. In most countries, supervisors have undertaken a thematic review of banks' NPL management capacity, issued formal guidelines to banks on NPL management practices, and issued regulations regarding provisioning (or communicated regulatory expectations about provisions under International Financial Reporting Standards). In some countries, supervisors provided additional incentives for write-offs, such as increased capital charges or time limits for carrying NPLs on balance sheets; performed assessments of collateral valuation practices; and subjected banks to granular asset quality reviews. In some countries (e.g., the Bahamas, Belize, and in the ECCU), supervisors have strengthened prudential rules for loan classification and provisioning, which helped improve provisioning and intensify write-offs. 
Notwithstanding these efforts, further work is needed in several areas. In most countries, no licensing and regulatory regime is in place to enable nonbanks to own or manage NPLs, which hampers the development of the NPL market. Many countries have no requirement to apply a real estate valuation standard, which contributes to uncertainty regarding collateral values and therefore poses an obstacle to liquidating collateral during debt enforcement. Difficulties in realizing collateral, in turn, increase banks' reluctance to address NPLs. Requiring banks to have operational targets for NPL reduction or time limits on carrying NPLs on their balance sheets, where these tools are absent, can create

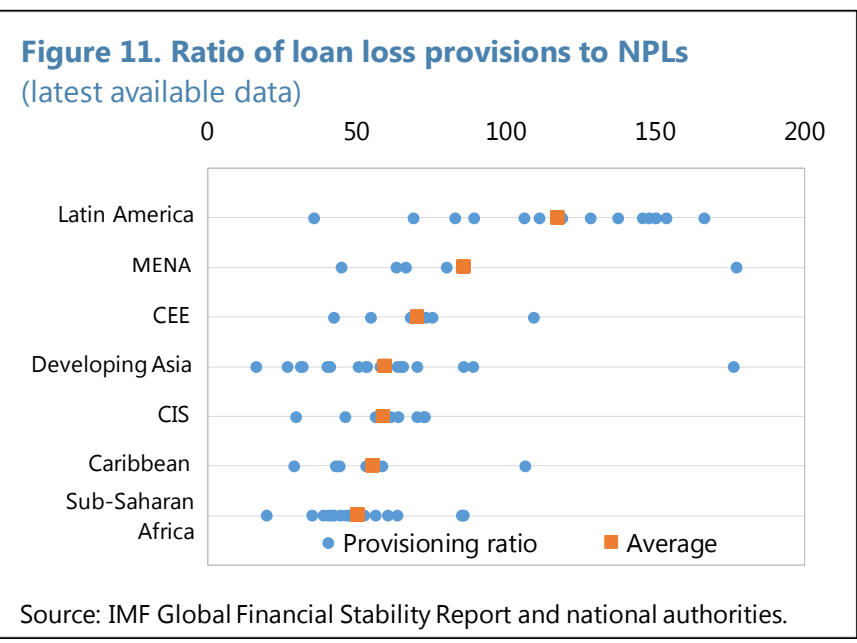
incentives for resolving NPLs. Finally, as discussed earlier, provisioning ratios are low in the Caribbean compared with many other regions, suggesting scope for greater provisioning to help recognize losses and write off loans (Figure 11).

Banks have the basic tools with which to address NPLs. Most banks have dedicated NPL workout units, and all banks are required to have NPL management strategies and action plans to reduce problem loans. In most countries, banks can also outsource NPL management. Survey responses suggest that banks use a variety of tools to restructure NPLs, including interest-only loans, reduced repayments, and performance-based write-offs (Figure 12). Restructured loans averaged about 10 percent of NPL portfolios in the sample, although they reached as high as 40 percent in a few banks. However, lack of coordination mechanisms among creditors and the absence of a market for problem loans constrain NPL resolution. Banks disposed of about 16 percent of their NPL portfolios (on average in 201315), mostly through write-offs. Difficulties in liquidating collateral and uncertainties regarding collateral valuations create incentives to keep distressed assets on bank balance sheets much longer than warranted, despite the availability of resolution tools. NPL management is also constrained by the lack of interbank or public-private creditor coordination. 

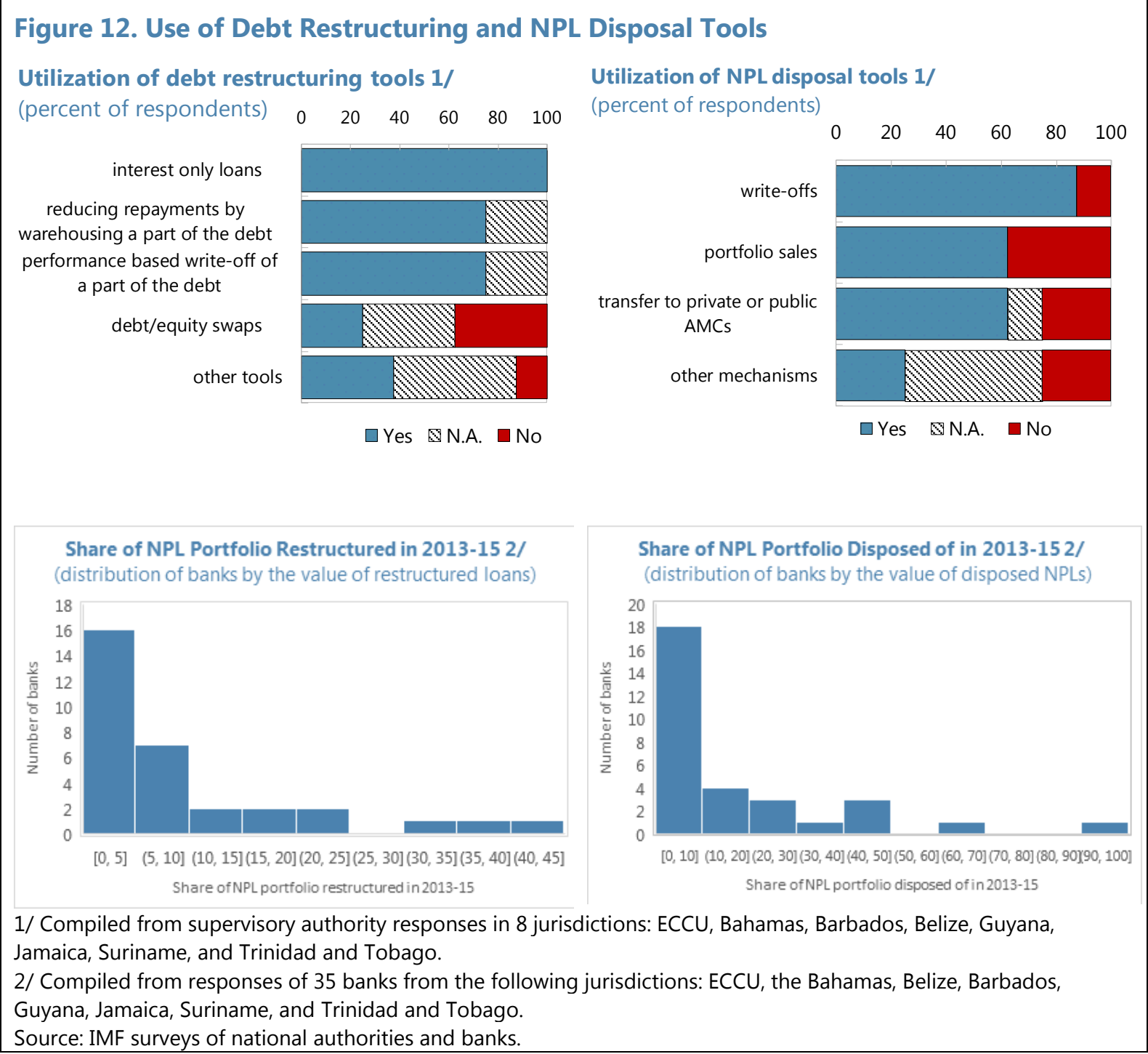

\section{B. Debt-Enforcement and Insolvency Framework}

Effective insolvency regimes and debt enforcement are essential for NPL resolution. An effective insolvency regime should provide mechanisms for creditors to realize their claims in a predictable, speedy, and transparent manner, while at the same time protecting and maximizing value for all parties (Aiyar and others 2015). An effective debt-enforcement and insolvency framework has, in turn, two pillars: first, an adequate resolution toolkit that provides for rehabilitation for viable firms and liquidation for non-viable firms (and in the case of personal insolvency, a second chance for good faith entrepreneurs while preserving credit discipline), and second, an effective institutional framework that operates in a predictable, efficient, and transparent manner (Hagan 2001). Strengthening insolvency regimes by enhancing insolvency laws (e.g., by including time bound processes, class voting 
by creditors, and a fast-track (pre-pack) ${ }^{13}$ insolvency procedure), creating incentives for outof-court settlement, and institutional reforms such as creating specialized courts were key elements of strategies for reducing NPLs in a number of countries. ${ }^{14}$

The surveys highlighted several gaps in the resolution toolkit and its implementation. Even though all countries have corporate insolvency regimes in place, many do not have fast-track pre-pack insolvency procedures or rehabilitation procedures for corporates, and only a few have out-of-court settlement mechanisms or actively promote such techniques (e.g., through guidance issued by the central bank or informal arrangements between banks). These gaps, in turn, impede business rescue, slow down realization of claims, and reduce expected recovery of value. Several countries reported that creditors do not have adequate control or influence over the process of business restructuring. Personal insolvency regimes exist in only half of the

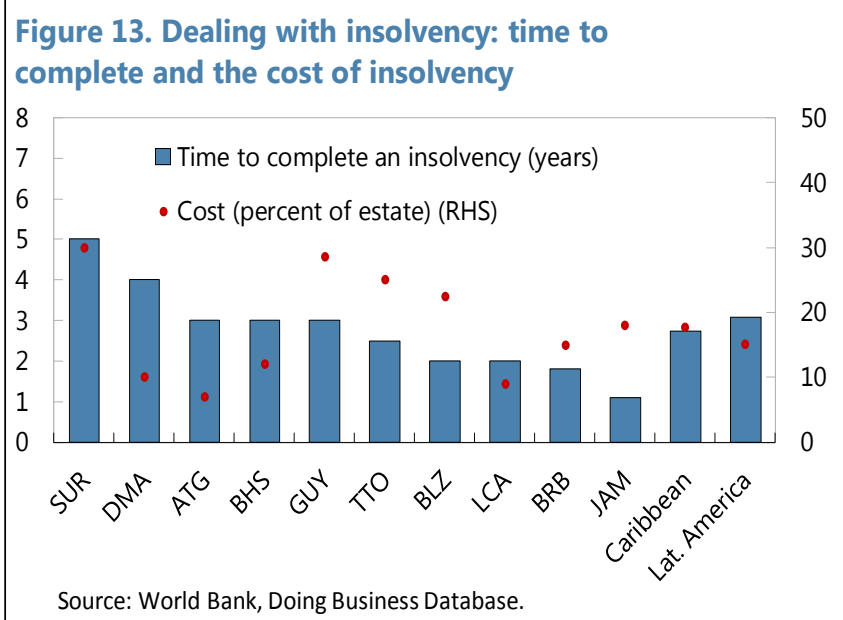

Source: World Bank, Doing Business Database. surveyed countries, and this regime is applicable to individual entrepreneurs in only two cases. Weak institutions are even a more significant concern-half of the surveyed banks consider implementation of insolvency and debt-enforcement regimes to be important obstacles to NPL resolution. Courts or judges that specialize in insolvency cases do not exist, and in the absence of time-bound procedures in many cases, resolving insolvency takes a long time - on average 2.7 years for the region, a high or medium-level concern for about 60 percent of the bank respondents (Figure 13). In the ECCU region, for example, foreclosure laws are typically debtor friendly, which considerably lengthens the foreclosure process and delays recovery by banks. These obstacles strain bank liquidity and reduce recovery rates, with subsequent adverse effects on credit provision and lending rates.

\section{Data Gaps and Impediments to Information Sharing}

Access to adequate information is essential for borrowers and creditors to price risk, value collateral, and narrow pricing gaps by reducing uncertainty. Public registries are important for maintaining complete information about credit and transaction histories and asset characteristics. The ability to share information for debt-workout purposes among creditors is

\footnotetext{
13 "Pre-packs" refer to procedures under which the court expeditiously approves a debt restructuring plan negotiated between the debtor and its creditors in a consensual manner before the initiation of an insolvency proceeding. This technique draws on a significant advantage of court-approved restructuring plans - the ability to make the plan binding on dissenting creditors - while leveraging a speedy out-of-court negotiation process.

${ }^{14}$ For example, in Indonesia and Thailand (1999), Turkey (2002), Japan (1999, 2008), and Korea (1998, 2006) (Aiyar and others 2015).
} 
also important. Reducing information asymmetries was a key pillar in strategies to reduce NPLs in many European economies. ${ }^{15}$

The surveys identified significant gaps in the information framework in the Caribbean (Figure 14). For example, 80 percent of banks consider that lack of credit registries significantly raises the cost of due diligence. Most countries do not have credit bureaus. Although most countries have land registries accessible to creditors, only four out of nine have registries of assets and real estate transactions, and access to the existing asset registries is more restricted. Even where registries exist, there are concerns about the quality of the data and access. For example, existing credit bureaus lack basic elements such as scoring for borrowers and information on connected borrowers. Four countries

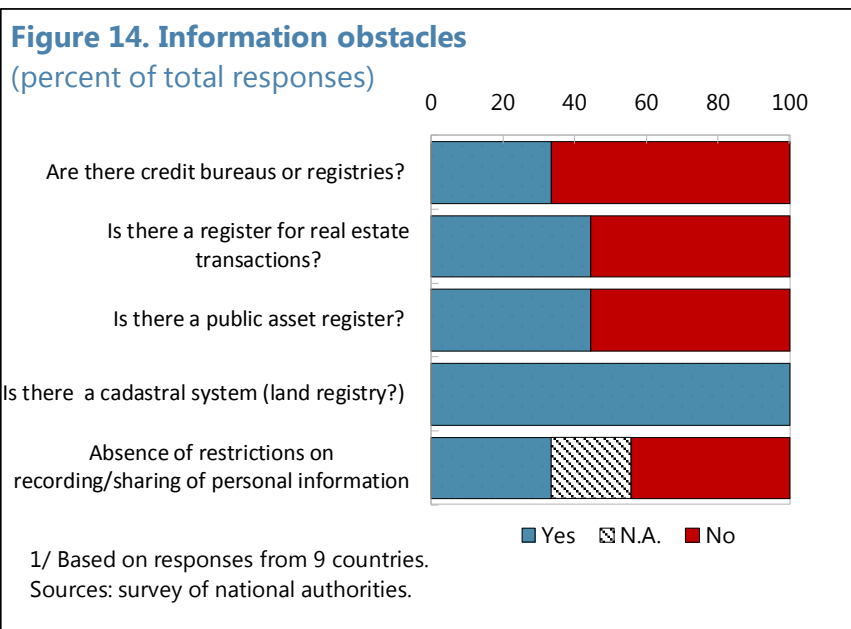
reported restrictions on recording and sharing of personal information for debt-workout purposes. These restrictions hinder the resolution of NPLs by undermining the debt-workout process in the absence of a full assessment of debtors' liabilities and wealth. The importance of addressing these information gaps is highighted by the experience of Jamaica, where the operationalization and increased use of credit bureaus since 2014 have helped incentivize borrowers to preserve good credit ratings and improve credit underwriting and management by deposit taking institutions, and played a role in reducing new NPLs and facilitating loan recoveries (Annex 1).

\section{Market for NPLs}

An active, liquid market for distressed debt can facilitate disposal of NPLs and reduce uncertainty about collateral valuations, thereby helping strengthen recovery values. Allowing banks to move problem loans off their balance sheets would reduce the burden on banks and can boost recovery values by providing a more cost-effective alternative to internal NPL management, especially for smaller banks that lack expertise and economies of scale in managing NPLs. Market approaches to dispose of NPLs may include direct sales, as well as securitization of NPLs. The latter has been used in a number of countries as a strategy for dealing with NPL overhang (e.g., Ireland and Spain) and as a useful approach to expanding the universe of distressed debt investors and to offering a way through which governments

\footnotetext{
${ }^{15}$ For example, Cyprus has set up a centralized credit registry, allowing banks to make more informed credit decisions. Serbia set up a database on real estate collateral valuations and loans secured by such collateral. Italy improved transparency and availability of NPL-specific data, fostering the development of a market for distressed assets.
} 
could jump-start the NPL market (e.g., by co-investing, together with private investors, in junior or mezzanine tranches). ${ }^{16}$

Survey responses show that markets for NPLs in the Caribbean are largely nonexistent, including in countries that do not have specific restrictions on trading NPLs. Half of the banks consider the lack of markets to be a medium- or high-level concern and, hence, an obstacle to resolution. Most countries reported no prohibitions on sales of NPLs to domestic or foreign buyers (Figure 15). ${ }^{17}$ Yet NPL sales are either sporadic or nonexistent. Many banks point out that the lack of a market for NPLs stems from large pricing gaps: values offered by potential buyers are much lower than the prices at which banks would be willing to sell their distressed assets. This may be a

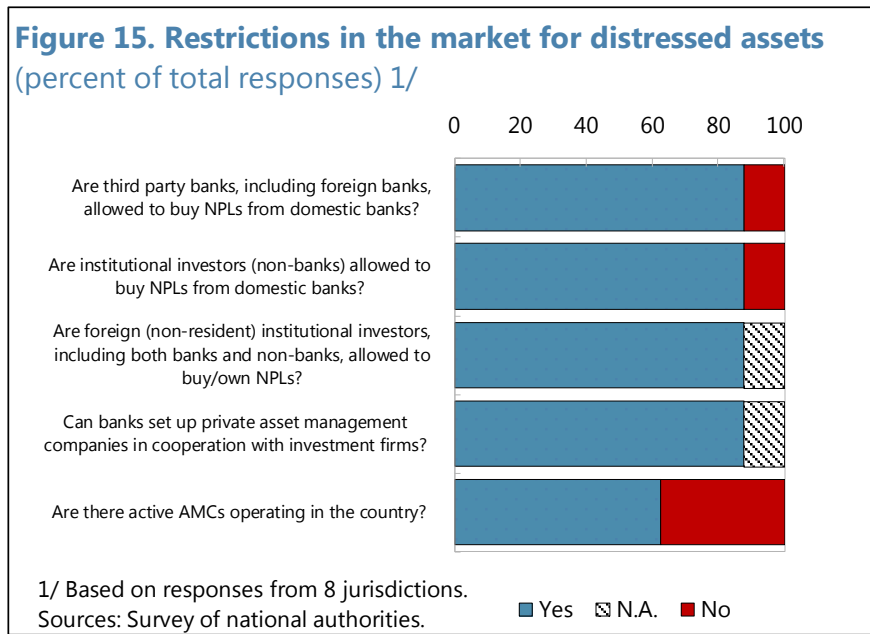
particularly important concern for banks with low levels of provisioning and capital to absorb the losses that could arise from selling bad assets. These considerations are similar to those highlighted by the surveys of European authorities and banks in Aiyar and others (2015).

\section{E. Tax Regime Obstacles}

Unfavorable tax treatment can create disincentives for adequate provisioning and loan writeoffs. The survey responses suggest that tax treatment of provisioning and write-offs are not a major concern for NPL resolution in the Caribbean (Figures 8 and 9). Only a small share of banks, most of which operate in two countries, flagged tax treatment as posing a medium or high concern for NPL resolution. This result stands in contrast with the actual rules, which suggest that tax treatment is not favorable in many countries. Half of the countries do not grant tax deductions for loan write-offs and

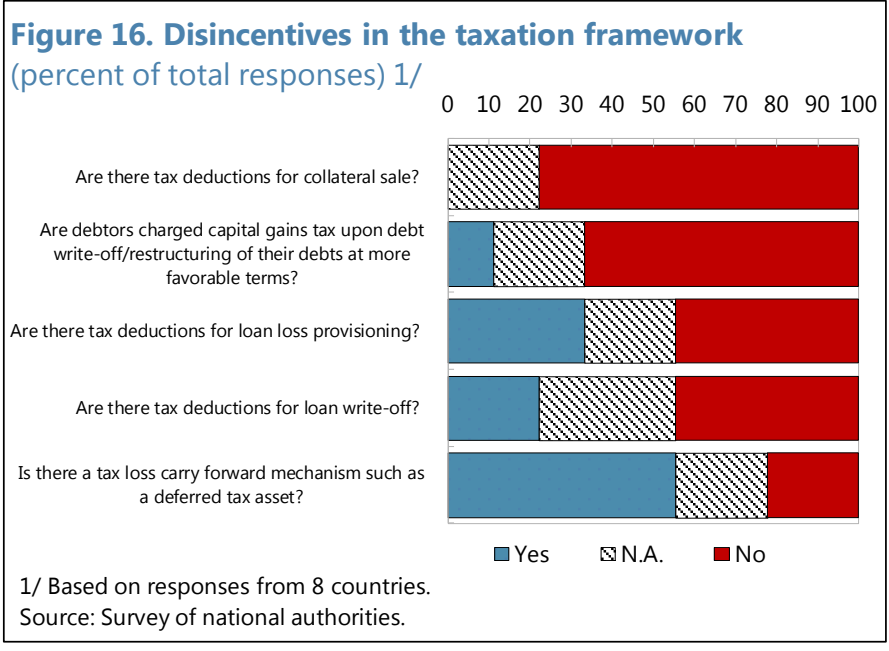

${ }^{16}$ See, for example, Aiyar and others (2015), Constâncio (2017b), and Lexology (2016).

${ }^{17}$ One potential obstacle to market development and sale of NPLs is the Alien Land Holding License requirement in several Caribbean countries (for example, some ECCU countries). Regional efforts to remove these obstacles are in process, but countries must agree to waive the legislation to allow for cross-border land and property purchases, and there is some resistance to doing so. 
loan loss provisioning, and two countries do not have a loss-carrying mechanism such as a deferred tax asset, thereby providing limited incentives for provisioning for or writing off impaired loans (Figure 16).

\section{WAY FORWARD: STRATEGY FOR NPL RESOLUTION}

The Caribbean NPL problem is a legacy of the global financial crisis, but its persistence at high levels owes much to continued weaknesses in economic growth in the region, as well as to structural impediments to their resolution. To address the problem, a multifaceted approach is needed involving macroeconomic policies to support growth and employment, prudential policies to ensure macro-financial stability, and a comprehensive strategy to reduce the structural bottlenecks for resolution of problem loans - including through tighter bank supervisory regimes; stronger insolvency, debt-enforcement, and legal frameworks; closing of information gaps; and development of markets for distressed debt (Figure 17) (see Liu and Rosenberg 2013, Bergthaler and others 2015, and Aiyar and others 2015).

Figure 17. Strategy to Address the Obstacles to NPL Resolution

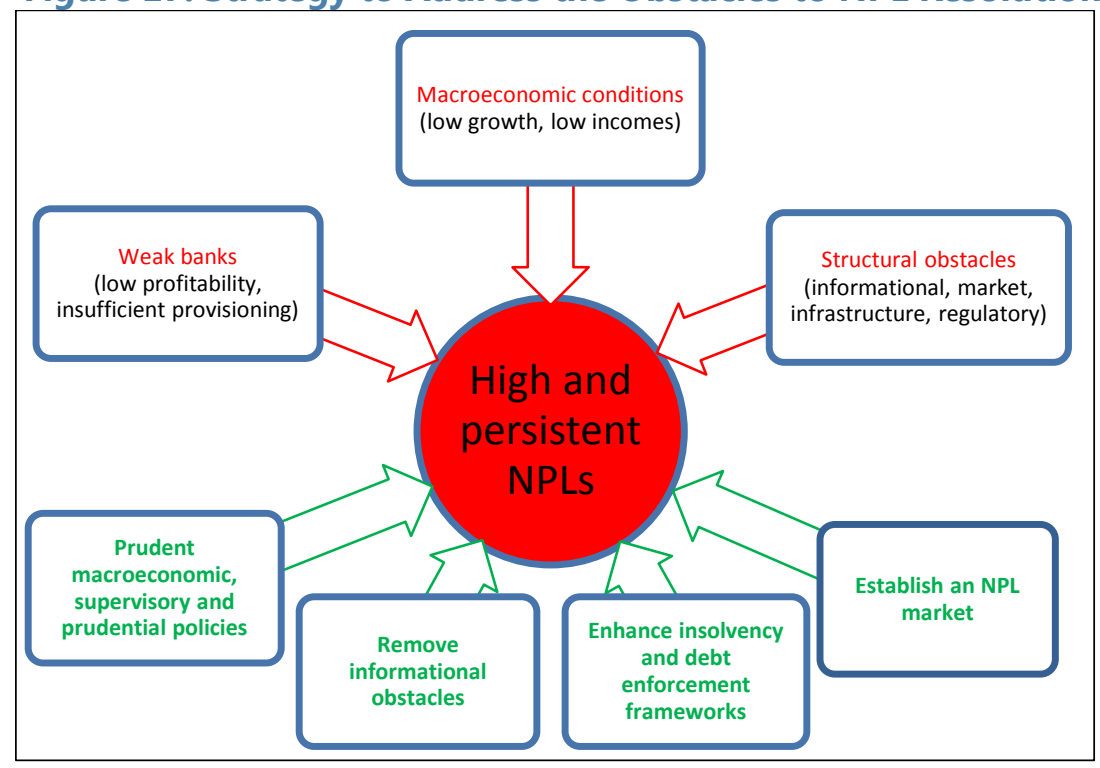

Strong macroeconomic policies. With macroeconomic conditions identified by banks and authorities in many countries as a key determinant of NPLs and one of the main obstacles to their resolution, priority should be given to implementing macroeconomic policies and structural reforms that promote strong and sustainable growth. Evidence suggests that growth recoveries associated with lower unemployment, higher household incomes, and higher corporate profits help resolve problem loans by improving the ability of firms and households to service their loans.

Strengthening prudential and supervisory frameworks. Strengthening supervisory and prudential frameworks, where needed, would help prevent a buildup of problem loans in the future. While the region is still at a low growth stage of the credit cycle, authorities could preemptively set up a toolkit of well-targeted prudential policies to reduce excessive risk taking during loan origination and to mitigate emerging risks subsequently identified. Strong 
supervisory regimes are also key to addressing existing problem loans. Banks must follow prudent loss-recognition and provisioning practices in line with international standards and apply appropriate real estate valuation standards to improve collateral valuation and liquidation during debt enforcement. Incentives should be in place to write off bad loans and increase provisioning to facilitate recognition of losses. ${ }^{18}$ Policies should also focus on facilitating outsourcing of NPL management, including establishing a regulatory framework for nonbanks to manage NPLs and fostering bilateral NPL sales, undertaking independent asset quality reviews, as well as ensuring high quality of governance and senior management oversight in banks. Effective coordination mechanisms between banks and between public and private creditors should be in place.

Addressing information gaps. Policies should focus on removing information gaps that hinder the pricing of risk, collateral valuation, and the narrowing of large pricing gaps between buyers and sellers of properties that hamper development of NPL markets. Where missing, efforts could focus on establishing well-functioning public registries and credit bureaus to reduce information asymmetries and improve management of credit risk, and on setting up public records on assets or real estate transactions to improve the functioning and revival of real estate markets. The quality of data also needs improvement even when registries exist. Improving data quality and closing data gaps are crucial not only to facilitate NPL resolution and foster market development, but also to address other regional challenges, such as the withdrawal of correspondent banks from the region and assessing emerging risks in the financial sector.

Improving insolvency and debt-enforcement frameworks is essential for a predictable and transparent system that enables business rescue (for corporates) or a second chance (for individuals) and helps creditors to realize claims promptly and protect recovery value. All countries have corporate bankruptcy regimes, but some countries could expand the toolkit by establishing fast-track and rehabilitation pre-pack procedures, , simplified procedures for SMEs and promoting out-of-court debt restructuring. Several countries could consider introducing personal bankruptcy mechanisms. Policies should focus on strengthening the institutions that support/implement the legal framework, for instance by improving judicial systems (a key obstacle noted in the surveys) to reduce the time required for resolution. Specialized courts and judges and experienced resolution professionals could strengthen the expertise necessary to facilitate timely and effective resolution.

Introducing a pan-Caribbean market for NPLs. The small size of the Caribbean economies, as well as structural obstacles such as gaps in the information framework and cultural and social factors, prevent development of a well-functioning domestic market for distressed assets to facilitate the disposal of NPLs. Access to timely information on distressed borrowers, collateral valuations, and recent NPL sales are critical for developing an active NPL market for distressed assets (Aiyar and others 2015). Moreover, distressed debt markets cannot develop unless banks are in a position to move NPLs off their books at a market price at their prevailing capital and provisioning levels. Policies should focus on building a market

\footnotetext{
${ }^{18}$ Such incentives could include additional capital charges and time limits for carrying NPLs on balance sheets, tighter provisioning requirements, or tax incentives for write-offs and loan-loss provisioning.
} 
based on a common pan-Caribbean platform open to external investors to create economies of scale and address some of the cultural and social obstacles, while also ensuring adequate capital and provisioning levels. Introducing asset management companies (AMCs) can help initiate markets; the experience with AMCs in the region is limited but promising (Box 2). ${ }^{19}$ While NPL securitization may not be a viable solution for the Caribbean at this juncture, given the small size and the level of development of financial markets, legislative or regulatory changes that may be needed to allow for securitization, and weaknesses in legal and regulatory frameworks, developing the necessary ingredients for securitizing NPLs could pave the way to using this tool as a means of pooling risk and facilitating the market for NPLs in the future.

While priority should be given to implementing the strategies outlined above, implementation may face challenges. Some of the strategy's measures, such as enhanced supervision to ensure loss recognition and provision, can be introduced quickly. However, others, such as legal reforms, measures to address informational obstacles, and establishing a market for problem loans, require time to implement. The strategy needs to recognize that each country would require a separate diagnostic that could help in prioritizing and sequencing the reforms, given the differences within the region. The institutional capacity constraints in small Caribbean states call for coordination of reforms within the region. Some of the ongoing regional initiatives, such as establishing a regional AMC and credit bureaus, enhancing insolvency and debt-enforcement regimes, and establishing guidelines for collateral valuation in the Eastern Caribbean region, are positive steps in this regard. ${ }^{19}$ Reforms should also be fine-tuned based on the detailed institutional framework and coordinated across stakeholders, such as the central bank and ministries of finance. National and regional efforts could be supported by well-targeted capacity-building assistance from international financial organizations.

\footnotetext{
${ }^{19}$ AMCs (both private and public) have been used in some countries, particularly Asia, to facilitate NPL disposal (for example, in Indonesia, Korea, Malaysia, Sweden, and Thailand) by separating good assets from bad, allowing the ceding banks and AMCs to focus on their respective objectives, and by helping close the gap between the price at which banks were willing to sell and investors were willing to buy, and in so doing helping to nurture a market for distressed assets (Aiyar and others 2015). More recently, the European Commission announced that it will come forward with a proposal for a comprehensive and coordinated strategy to deal with NPLs, including a blueprint for national AMCs, which could provide some insights for the Caribbean region (Constâncio 2017a).
} 


\section{Box 2. Asset Management Companies (AMCs) in the Caribbean}

AMCs can enable more efficient collection and disposal of distressed assets and help maximize the value of impaired assets in the banking system, while at the same time preventing credit discipline from deteriorating. International evidence (see, for example, Klingebiel 2000) points to mixed experience in the use of AMCs and suggests that there is no single recipe for establishing a successful AMC. However, common factors for successful AMCs include a supporting legal and regulatory environment, strong leadership, operational independence, appropriate incentives, and a commercial orientation (Ingves, Seelig, and He 2004).

A large majority of Caribbean banks that responded to the IMF survey argue that banks can set up private AMCs and that indeed there are active AMCs operating in their countries. At the same time, there are few examples of operational public AMCs.

- Eastern Caribbean Currency Union (ECCU). In the context of bank restrictions within the ECCU, the Eastern Caribbean Central Bank has created an AMC to resolve problem loans. A regional asset management company - Eastern Caribbean Asset Management Company (ECAMC) - has been granted extraordinary powers to acquire collateral and to resolve problem loans. ECAMC will acquire the problem loans from three resolved ECCU banks (Annex 2) and will be able to purchase NPLs from other banks in the region. A new banking act was passed by all ECCU jurisdictions providing the legislation for the establishment of the ECAMC. It is anticipated that ECAMC will operate for three years.

- The Bahamas. Both public and private AMCs have made some progress in removing bad loans from bank balance sheets. First, in 2014, the government established a special purpose vehicle (Bahamas Resolve) to manage $\$ 100$ million of nonperforming commercial loan assets from the largely state-owned Bank of the Bahamas. There has reportedly been little to no progress in sale of the underlying real estate assets. Second, one commercial bank operating in The Bahamas sold a portfolio of NPLs (about \$75 million) to a newly established specialized mortgage servicing company (Gateway). Anecdotal evidence suggests that the experience has been positive thus far, with no major consumer protection complaints related to loan restructuring and potential for other banks to follow suit. 


\section{REFERENCES}

Arellano, M., and S. Bond. 1991. "Some Tests of Specification for Panel Data: Monte Carlo Evidence and an Application to Employment Equations." Review of Economic Studies 58 (2): 277-97.

Arellano, M., and O. Bover. 1995. "Another Look at the Instrumental Variable Estimation of Error-Components Models.” Journal of Econometrics 68 (1): 29-51.

Aiyar, S., W. Bergthaler, J. M. Garrido, A. Ilyina, A. Jobst, K. Kang, D. Kovtun, Y. Liu, D. Monaghan, and M. Moretti. 2015. "A Strategy for Resolving Europe's Problem Loans." IMF Staff Discussion Note 15/19, International Monetary Fund, Washington, DC.

Bank for International Settlements. 2016. Guidelines on Prudential Treatment of Problem Assets-Definitions of Nonperforming Exposures and Forbearance. Basel: Bank for International Settlements.

Beaton, K., T. Dowling, D. Kovtun, F. Loyola, A. Myrvoda, J. Okwuokei, I. Ötker, and J. Turunen. Forthcoming. "Problem Loans in the Caribbean: Determinants, Impact, and Strategies for Resolution.” IMF Working Paper, International Monetary Fund, Washington, DC.

Beaton, K., A. Myrvoda, and S. Thompson. 2016. "Non-Performing Loans in the ECCU: Determinants and Macroeconomic Impact.” IMF Working Paper 16/229, International Monetary Fund, Washington, DC.

Beck, R., P. Jakubík, and A. Piloiu. 2013. "Non-Performing Loans: What Matters in Addition to the Economic Cycle?" European Central Bank Working Paper 1515, European Central Bank, Frankfurt.

Bergthaler, W., K. Kang, Y. Liu, and D. Monaghan. 2015. "Tackling Small and Medium Sized Enterprise Problem Loans in Europe.” IMF Staff Discussion Note 15/04, International Monetary Fund, Washington, DC.

Blundell, R., and S. Bond. 1998. "Initial Conditions and Moment Restrictions in Dynamic Panel Data Model." Journal of Econometrics 87 (1): 115-43.

Constâncio, Vítor. 2017a. "We need a coordinated European NPL strategy: How to deal with Europe's market for lemons?" Opinion piece by Vítor Constâncio, Vice-President of the European Central Bank, 5 July 2017.

Constâncio, V. 2017b. "Resolving Europe's NPL burden: Challenges and Benefits." Keynote Speech at an event entitled "Tackling Europe's non-performing loans crisis: restructuring debt, reviving growth" organized by Bruegel, Brussels. February 2.

Espinoza, R., and A. Prasad. 2010. "Nonperforming Loans in the GCC Banking System and their Macroeconomic Effects." IMF Working Paper 10/224, International Monetary Fund, Washington, DC. 
Hagan, S. 2001. "Insolvency Reform and Economic Policy." Connecticut Journal of International Law 17 (63): 63-73.

Holtz-Eakin, D., W. Newey, and H. S. Rosen. 1988. "Estimating Vector Autoregressions with Panel Data." Econometrica 56 (6): 1371-95.

Ingves, S., S. Seelig, and D. He. 2004. "Issues in the Establishment of Asset Management Companies.” IMF Policy Discussion Paper 04/3, International Monetary Fund, Washington, DC.

Jordan, A., and C. Tucker. 2013. "Assessing the Impact of Nonperforming Loans on Economic Growth in The Bahamas.” Monetaria I (2): 371-400.

Klein, N. 2013. "Non-Performing Loans in CESEE: Determinants and Impact on Macroeconomic Performance.” IMF Working Paper 13/72, International Monetary Fund, Washington, DC.

Klingebiel, D. 2000. "The Use of Asset Management Companies in the Resolution of Banking Crises: Cross-Country Experiences.” Policy Research Working Paper 2284, World Bank, Washington, DC.

Nickell, S. J. 1981. "Biases in Dynamic Models with Fixed Effects.” Econometrica 49 (6): 1417-1426.

Nkusu, M. 2011. "Nonperforming Loans and Macrofinancial Vulnerabilities in Advanced Economies." IMF Working Paper 11/161, International Monetary Fund, Washington, DC.

Liu, Y., and R. Rosenberg. 2013. "Dealing with Private Debt Distress in the Wake of the European Financial Crisis: A Review of the Economics and Legal Toolbox." IMF Working Paper 13/44, International Monetary Fund, Washington, DC.

Tintchev, K. Forthcoming. "Commodity Price Shocks and Bank Credit Quality in the Caribbean.” IMF Working Paper, International Monetary Fund, Washington, DC. 


\section{Annex I. Case Studies on Resolving NPLs in Selected Caribbean Countries ${ }^{1}$}

\section{The Bahamas}

The stock of NPLs rose sharply, reflecting a deterioration of mortgage loan quality in the aftermath of the global financial crisis. NPLs remain elevated and continues to delay the recovery in private sector credit and economic growth, but there appears to be no immediate threat to financial stability, owing in part to banks' large capital buffers and a strengthened regulatory and supervisory framework. Banks have been taking concrete steps towards NPL resolution, including through restructuring and write-offs, but information gaps, a depressed real estate market, inefficiencies in contract enforcement, and high cost of property registration are weighing on efficient NPL resolution. Speeding up the resolution of NPLs requires a comprehensive approach that addresses these obstacles, and could benefit from establishment of a specialized agency, such as an Asset Management Company.

Size, structure, and evolution of NPLs. The NPL ratio of domestic banks rose sharply from 4.5 percent at end-2007 to a peak of 15.3 percent in 2014, due in large part to a deterioration in the mortgage portfolio (57 percent of the total stock of NPLs). The stock of consumer and commercial NPLs dropped in 2015 thanks to significant write-offs and government support of a state-owned bank, reducing the overall NPL ratio to 14.2 percent. Delinquency rates in commercial loans remain the highest at 21.9 percent of total loans, followed by residential mortgages at 18.5 percent at end-December 2015. Depressed property values continue to

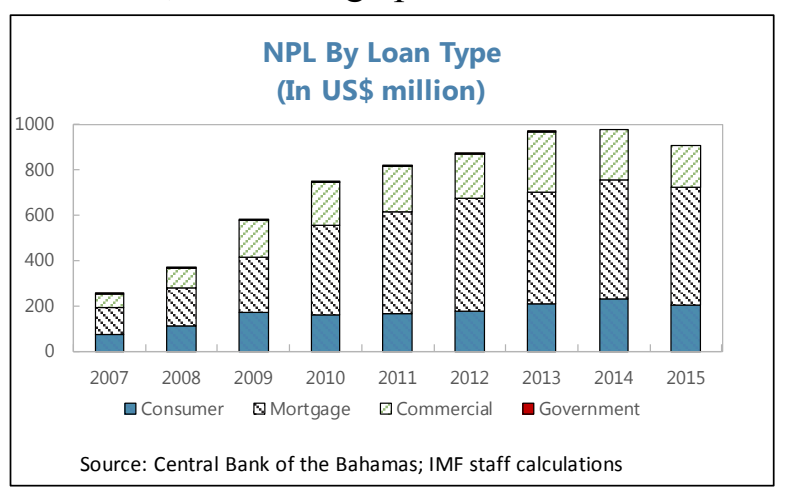
make banks reluctant to foreclose on properties and keep NPL ratios elevated for mortgages. In contrast, NPL ratios on consumer loans, typically unsecured, are lower, at 8.6 percent, because banks tend to write off delinquent consumer loans after 180 days.

\footnotetext{
${ }^{1}$ The case studies are based on the available information provided by survey results, and data and information provided by the national authorities, Financial Sector Assessment Reports, and country desk economists.
} 
Key drivers of NPLs. The sharp rise in NPLs reflects persistent weaknesses in economic activity after the crisis and its subsequent impact on the mortgage market. Real GDP contracted at an annual rate of $1 / 2$ percent on average over 2008-2015, with no growth in three years since 2013. With weak economic activity, the unemployment rate jumped by 5.5 percentage points to 14.2 percent in 2009 and remained in double digits. Near-term growth and employment prospects have been hampered by repeated delays in the opening of the Baha Resort, which is expected to create some 5,500 jobs.

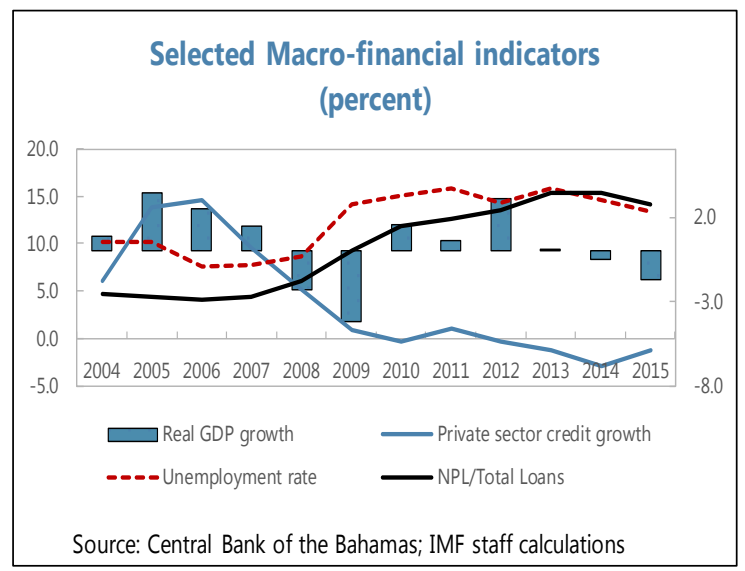

Implications of NPLs for the financial and economic activity. With the sizable private sector debt burden, domestic banks have tightened lending standards and have been reluctant to lend. Further delays in the recovery of private sector credit, in turn, have dampened economic activity. Prudential indicators continue to point to a liquid, profitable, and wellcapitalized domestic banking system, with the overall banking system capital adequacy at 30 percent of risk-weighted assets, at end-2015, well above the regulatory requirement of 17 percent.

Resolution framework. The regulatory and supervisory framework for NPL resolution appears strong, based on the findings of the April 2013 Financial Sector Assessment Program. Compliance with the Basel Core Principles (BCP) for Effective Banking Supervision was assessed as good, with loan-loss provisioning and loan impairment regulations and practices consistent with international standards. The oversight of the financial system has been strengthened since 2004, with a strong bank supervision department supported by dedicated and well-trained staff, a blend of onsite/offsite tools, quarterly discussions with banks, and implementation of risk-based supervision. The Central Bank issued guidelines that establish benchmarks for loan classification and specific and general provisions. Credit risk management and impaired asset requirements comply with the $\mathrm{BCP}$, although financial reporting that follows IFRS standards provides some discretion in the treatment of impaired assets. The Central Bank closely monitors NPL evolution and collateral valuation, but the latter could be improved (e.g., with the construction of a real estate price index). Preparatory work to establish a credit bureau is advancing.

Main impediments to resolution. Weak economic growth remains a major obstacle. Lack of demand for real estate, which has depressed property values, continues to hinder the resolution of nonperforming mortgages. Excessive delays in and high costs of property registration, low data quality in the cadastral system and inefficiencies in the enforcement of contracts also likely weigh on progress with NPL resolution. There is scope to expand the coverage of the existing public asset registry to include heavy equipment. A real estate transactions register is not in place. Better access to credit data through a legislated entity could improve resolution rate. There appears to be no legal or regulatory restrictions on 
trading NPLs, although transactions may require regulatory approval. In addition, banks are reluctant, for both economic and social reasons, to press for accelerated resolution.

Resolution strategies implemented and outcomes. Some progress has been made in removing bad loans from bank balance sheets. The Central Bank has intensified monitoring of impaired assets and underlying collateral, including through regular meetings with banks. It has urged banks to be more aggressive in their collateral valuation practices, including accounting for the time cost of recovery. Banks appear to have responded, and have been active in NPL resolution. Loan write offs from 2008-2015 amounted to 7.2 percent of total loans at end-2015, while the stock of restructured loans was 12 percent of total loans. Provisioning for bad loans has improved as well, and in some cases banks have incurred sizable losses and foregone dividends. In 2014, the government established a special purpose vehicle (Bahamas Resolve) to manage $\$ 100$ million of nonperforming commercial loans from the largely state-owned Bank of the Bahamas. However, there has reportedly been little to no progress in sales of the underlying assets. One commercial bank has recently sold a small portfolio of NPLs (about \$75 million) to a newly established specialized mortgage servicing company (Gateway). Anecdotal evidence suggests that the experience has been positive thus far, with no major consumer protection complaints related to loan restructuring, and potential for other banks to follow suit. The government's recent introduction of a Mortgage Relief Plan provides additional opportunities for loan restructuring.

\section{Belize}

The stock of NPLs in Belizean banks remains sizable, after increasing sharply during the global financial crisis with weaknesses in prudential rules, lenient underwriting standards, and the impact of the crisis on economic activity. Private sector credit growth has been slow to recover, in part reflecting high NPLs. Despite notable improvements recently, NPL resolution continues to be hampered by structural impediments, including weaknesses in collateral valuation, information gaps, a lengthy liquidation process, and an illiquid real estate market. Banks' balance sheets have strengthened recently and NPLs continue to decline as a result of ambitious financial sector reforms and the authorities' determination to keep the banking system under tight supervision.

Size, structure, and evolution of NPLs. NPLs of the banking system, including both domestic and international banks, ${ }^{2}$ increased sharply from 6.6 percent of total loans in 2007 to 21.3 percent in March 2011, reflecting, in part, a reclassification of loans that were previously reported as performing. The NPL ratio has steadily declined since then, to 9.8 percent in end-March 2017, reflecting mostly write-offs of bad loans. About 56 percent of the NPLs originated from the construction and real estate sector, while commercial mortgages represent around one-fifth of total NPLs. At end-March 2017, more than half of the weak loan portfolio was in the domestic banking system, with the share of NPLs of the two

\footnotetext{
2 In Belize, the terms "domestic banks" and "international banks" indicate banks" functions rather than their origin: international banks are those that collect deposits and other liabilities from nonresidents and provide loans mainly to nonresidents, including those who invest in Belize. Domestic banks collect deposits from residents - they can be either locally or foreign-owned. Both domestic and international banks are regulated and supervised by the Central Bank of Belize.
} 
foreign-owned banks around 40 percent of domestic banks total. Large exposures (10 percent of capital) have led to risk concentration in a small number of borrowers.

Key drivers of NPLs. The sharp deterioration in asset quality around 2011 reflects weaknesses in the framework for loan classification, provisioning, and collateral valuation, as well as the effects of the global financial crisis on activity in key economic sectors. Prudential rules were assessed to have fallen short of international practice in several areas by the 2011 FSAP. This, together with loose underwriting standards, encouraged excessive risk taking by some banks. In one bank, sizable NPLs originated from bad lending decisions over

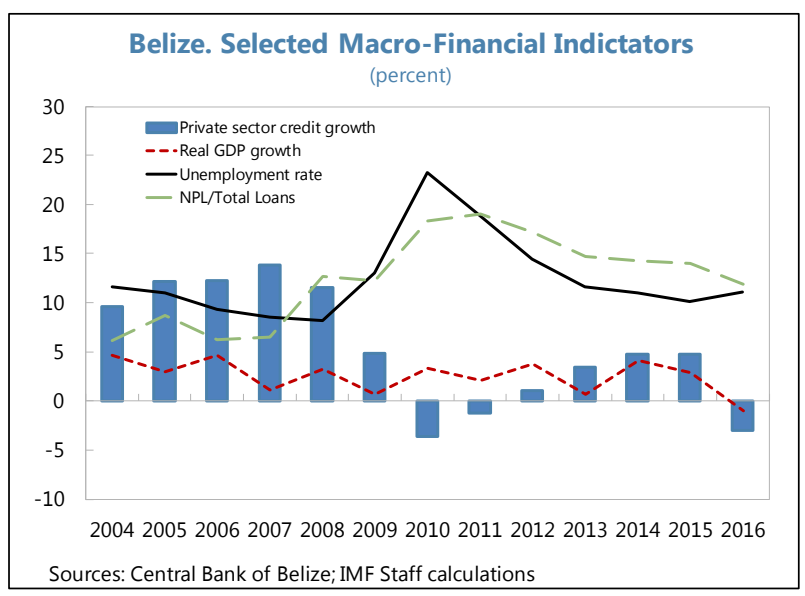
many years to a few influential and connected large borrowers.

Implications of high NPLs. While the impact of the high stock of NPLs on economic activity appears muted, with real GDP growth broadly stable (2 percent on average over 2012-16), the debt overhang, loan write-offs, and increased provisioning weighed down on bank profitability and balance sheets, dampening private credit growth that had been robust in double digits until 2009. After turning negative in 2010, when the NPL ratio reached its peak, credit growth has started recovering slowly but remained low, despite abundant liquidity in the domestic banking system.

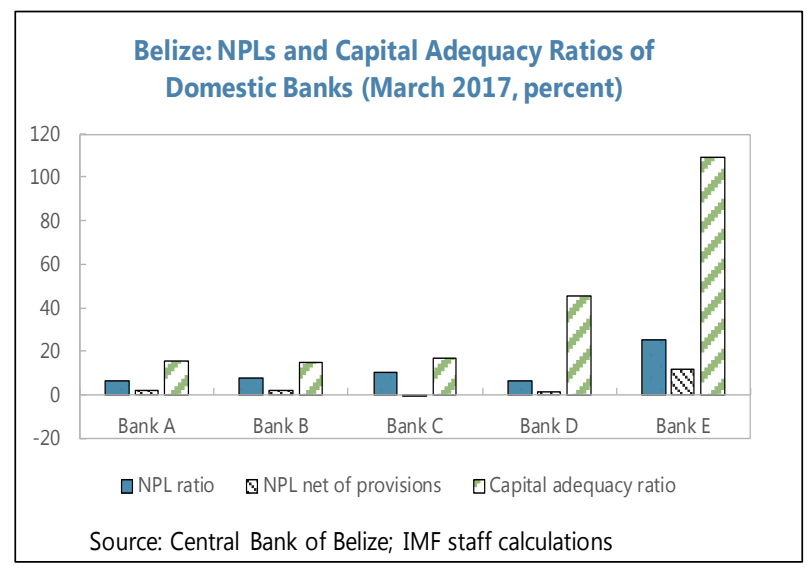

Resolution framework. There have been significant changes in the existing framework for NPL resolution since 2011. The Central Bank introduced new loan classification and provisioning standards in December 2011, mandating banks that are excessively exposed to credit risks to provision at levels that would ensure capacity to absorb future losses. The new standards encouraged banks to focus more on borrower's repayment capacity rather than the value of collateral, in contrast with the past when only unsecured loans that were one-year past due were classified as loss and secured loans were neither subject to specific provisions nor classified as loss irrespective of the length of the overdue payment period. Moreover, banks have started to build capacity for dealing with bad debts, and upgraded their underwriting standards. There are no direct impediments for developing markets for NPLs and no regulation prohibits the trade of NPLs with other banks or third parties. Banks have dedicated NPL units and appear to have an adequate NPL restructuring toolkit.

Main impediments to resolution. Notwithstanding the recent improvements, the resolution framework continues to be hampered by structural impediments. Whereas most bank lending is secured by land and real estate properties, the real estate sector is still weak and the 
liquidation process is long, unchanged since the 2011 FSAP. The Central Bank has the power to ask financial institutions to reappraise collateral on a case-by-case basis, but this procedure is very cumbersome. The supply of other forms of collateral is severely limited, given the small stock of marketable government securities and an underdeveloped capital market. There are also weaknesses in debt enforcement and the insolvency regime: it takes a long time to resolve a corporate insolvency, which lengthens time needed to resolve corporate NPLs. There are also significant data and information gaps, including: banks relying on a private bureau with voluntary participation in the absence of a formal credit bureau; lack of public registers for movable property and for real estate transactions; and weaknesses in the land registry system.

Resolution strategies implemented and outcomes. Besides tightening prudential requirements, as recommended by the 2011 FSAP, the authorities have made changes to the regulatory framework in the context of a broader financial sector reform to strengthen the supervisory capacity of the Central Bank. The domestic banking law was revised in 2012, including by raising penalties for contravening central bank regulation and guidelines. Furthermore, banks were restricted from declaring, paying dividends and repatriating profits until: (i) all prior losses have been written off, (ii) all impaired loans and other assets are adequately provisioned, and (iii) banks complied with all directives of the Central Bank, including on single borrower limits and capital and reserves. The Central Bank has also imposed further restrictions on some weak banks until it is fully confident that the banks are in a sound financial position. Bank balance sheets have strengthened as a result of ambitious financial sector reforms and the authorities' determination to keep the banking system under tight supervision. NPLs have been declining, while provisioning continues to increase. The capital adequacy ratio (CAR) rose to 25 percent at end-March 2016, the highest level in several years, owing in part to capital injection, sale of assets, and modest profits recorded. However, capital buffers in some banks may be inflated because of still low provisioning.

\section{The Eastern Caribbean Currency Union}

NPLs in the ECCU rose well above their prudential levels following the global financial crisis. As in many jurisdictions, the construction and tourism sectors were significant contributors. The resulting debt overhang and high NPLs has been a drag on growth, with credit growth remaining subdued. Efforts to rectify the situation have included completion of an asset quality review (AQR) to examine the soundness of bank balance sheets, the establishment of a regional asset management company (AMC) to resolve problem loans from pooled resources, and advancements toward the introduction of a credit reporting agency, collateral valuation standards, and new provisioning regulation. These efforts in large part have contributed to the decline in NPLs from their peak in 2013.

Size, structure, and evolution of NPLs. NPLs in the ECCU stood at 11.8 percent of total loans at end-2016, down from a peak of 18.3 percent in 2013, but stand well above the prudential guideline of 5 percent. Some disparities continue to exist across the ECCU jurisdictions, with the NPL ratio ranging from 5 percent in Monserrat to 16 percent in St. Lucia at end-2016. While foreign-incorporated banks had 9 percent of their loans classified as nonperforming, locally-incorporated banks' NPLs stood at 14 percent at end-2016. By March 2017, however, the ECCU-wide NPL ratio fell further to 11 percent, in part reflecting 
the resolution of three banks in Antigua and Barbuda and Anguilla. ${ }^{3}$ The resolution largely accounted for the sharp decline in Anguilla's NPLs from 50.4 percent in the first quarter of 2016 to 6.5 percent of loans by end-2016. The highest NPL ratios in the ECCU continue to be in the construction ( 34 percent), tourism ( 30 percent), and agriculture ( 23 percent) sectors, which also experienced the largest NPL increases since 2005.

Key drivers of NPLs. The accumulation of NPLs between 2003 and 2015 in the ECCU is a legacy of the global financial crisis, suggesting that macroeconomic developments play a key role. As in many countries, the construction and the tourism sectors experienced the largest increases in NPLs, because the crisis halted financing of large scale projects, the residential housing market was affected by both financing and household balance sheet concerns, and spending on tourism fell significantly. Some country-specific factors also contributed, such as the one-time impact of the debt-for-land swap in St. Kitts and Nevis.

NPLs remained high after the onset of the crisis, reflecting the slow global recovery, low provisioning levels to absorb losses from write-offs, insolvency of three banks (Moore and Souto, 2016), and banks' limited capacity to manage and liquidate problem loans. Beaton and others (2016) find weak economic growth (with real GDP growth averaging around 1.3 percent per annum since the crisis, compared to global growth around 3.5 percent) creating persistence in high levels of NPLs. Low profitability, due in part to the slow macroeconomic environment, has limited banks' ability to properly provision and write off bad loans. Three banks with deteriorating asset quality became insolvent during the postcrisis period, adding to the stock of NPLs. Managing problem loans is a resource drain for any bank, but banks that have low profitability have even fewer available resources to properly manage NPLs. Resolution of NPLs is also constrained by slow legal systems, debtor-friendly foreclosure laws, difficulties in collateral valuations, information asymmetries in the absence of an operating credit bureau, and shallow markets in which to sell recovered collateral.

Implications of high NPLs. The debt overhang creates adverse macro-financial feedback loops in the ECCU. Credit growth remains weak since the global financial crisis, with private sector credit contracting for the fourth consecutive year in 2016. Some of the slowdown is due to subdued credit demand, but lower credit supply also plays a role, since NPLs induce banks to tighten underwriting standards. Elevated levels of NPLs also call into question the adequacy of capital reserves and provisioning. At end-2016,

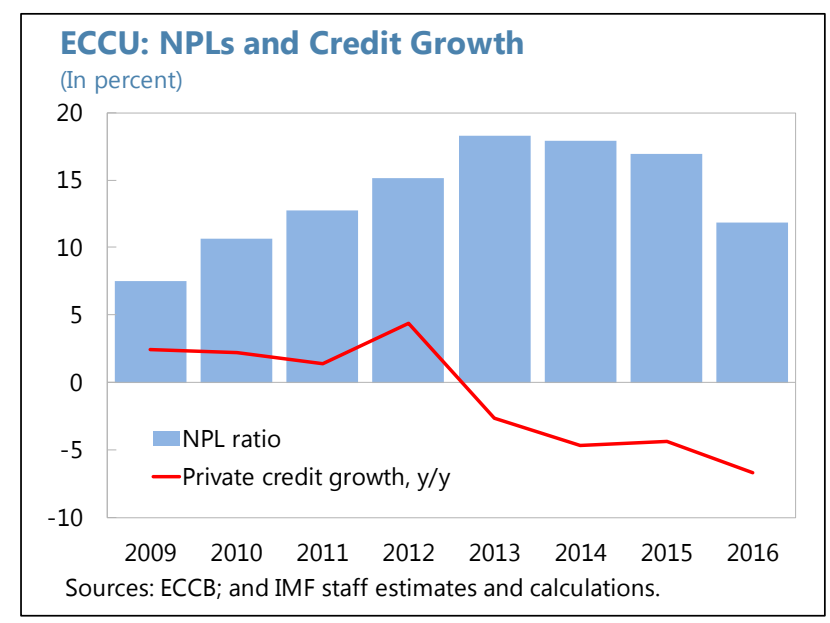

\footnotetext{
3 Three banks in Antigua and Barbuda and Anguilla were formally resolved between November, 2015 and April, 2016, after having been intervened by the Eastern Caribbean Central Bank (ECCB) in 2011, namely, the Antigua and Barbuda Investment Bank (ABIB), Caribbean Commercial Bank CCB and the National Bank of Anguilla (NBA). The ECCB assumed control of ABIB in July, 2011.
} 
the NPLs net of provisions stood at 36 percent of capital, suggesting low capital buffers relative to NPLs. Difficulties with collateral valuation could also overstate the adequacy of provisioning - at 46 percent of NPLs at end-2016. High NPLs were a contributing factor to the insolvency of the three banks that were put into conservatorship and subsequently resolved in 2015-16, while their nonperforming assets were placed into receiverships.

Resolution strategies implemented and outcomes. Along with the resolution of the three ECCU banks, the ECCB created an asset management company, Eastern Caribbean Asset Management Corporation (ECAMC), which was granted extraordinary powers to resolve NPLs, and is anticipated to operate for three years. The AMC is expected to acquire NPLs from the three failed banks, and will also be able to purchase NPLs from other banks in the region. The authorities have also made advancements toward the introduction of a credit reporting agency,

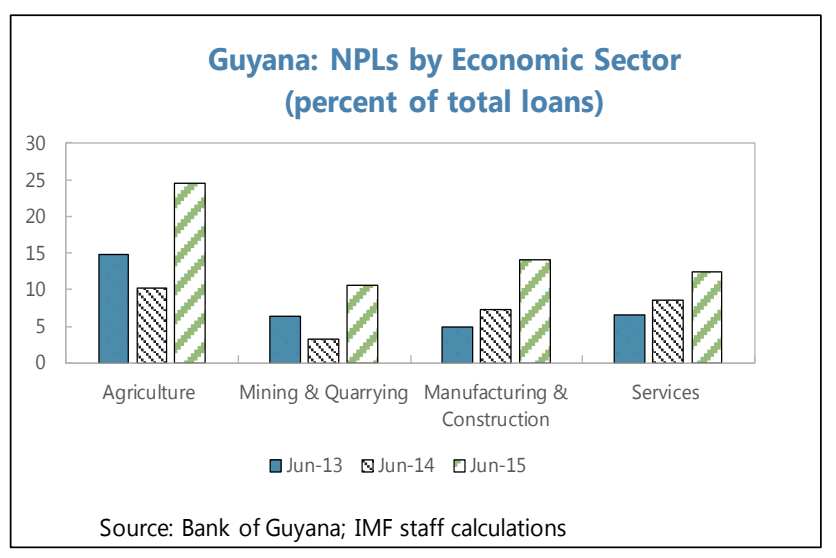
with the supporting regulation currently under review by the private sector. An asset quality review (AQR) was completed in 2015, which examined banks' loan portfolios, capital adequacy, and viability, and found provisioning to be low for some indigenous banks. The authorities are working to establish real estate valuation standards, to provide banks with guidelines to value real estate-related transactions. These standards, together with the new provisioning regulations, are expected to encourage faster provisioning of NPLs and improve the quality of credit decisions, thereby reducing the risk of future NPLs. Efforts to strengthen the supervision framework are ongoing, including with technical assistance from IFIs. ECCU member governments are working with the ECCB and the World Bank to develop the institutional framework for a regional Partial Credit Guarantee Scheme to facilitate access to credit, particularly for SMEs.

\section{Guyana}

After declining steadily for more than a decade, the stock of NPLs has risen, reflecting the sharp drop in global non-fuel commodity prices, slowdown in economic activity in Guyana, and structural obstacles to a quick resolution of impaired assets. The obstacles include an inefficient judicial system, information barriers, deficiencies in the supervisory regime, and the lack of a distressed debt market. The pace of private credit expansion has slowed, reflecting in part rising NPLs. The banking system's capital buffers are well above the regulatory requirements, but under-provisioning, weaknesses in loan classification, and related party exposures limit loss recognition. The authorities continue to closely monitor the strength of the financial system, and further reforms will be guided by the recommendations of the 2016 FSAP.

Size, structure, and evolution of NPLs. NPLs doubled, to 11.5 percent of total loans (5 percent of total assets) in 2015 from 5.9 percent in 2013 (3 percent of assets). The increase was economy-wide, but more pronounced in primary and secondary sectors, including agriculture, manufacturing and mining and quarrying, which together accounts for around 40 
percent of total NPLs. About one-quarter of loans in agriculture is nonperforming. NPLs are unevenly distributed and concentrated across banks, with the NPL ratio ranging from 10 percent in one bank to 23 percent in another, and with half of NPLs in the banking system concentrated in one domestic bank.

Key drivers of NPLs. Guyana is a commodity and agriculture-dependent economy with key exports, including gold, sugar, bauxite, and rice, accounting for roughly 30 percent of GDP and 80 percent of merchandize exports in 2015. The recent sharp decline in global non-fuel commodity prices, and the ensuing economic slowdown in Guyana contributed to the rise in NPLs. Other factors may also have a played role. The 2016 FSAP raised concerns about weaknesses in credit risk management in some banks. Inadequate loan classification and provisioning practices and timeliness and effectiveness of Bank of Guyana's (BoG) remedial actions were also issues highlighted by the FSAP.

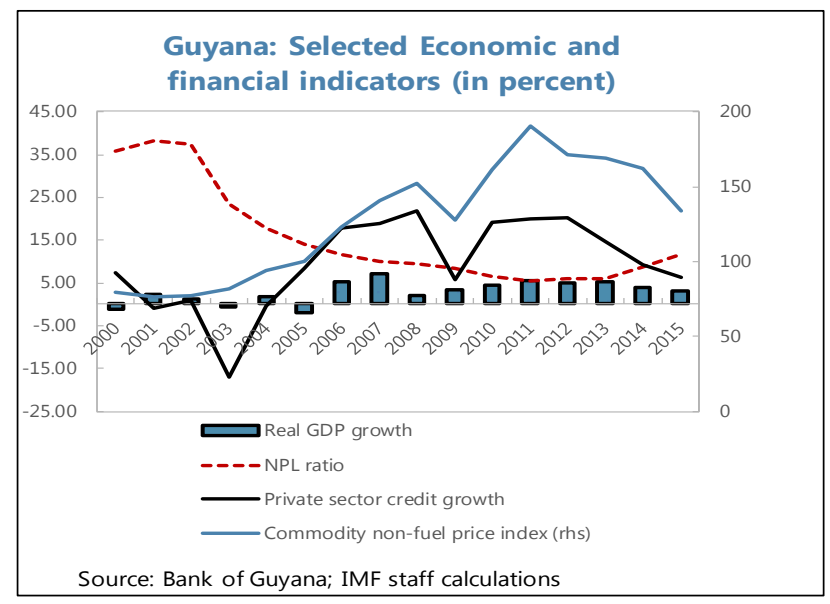

Implications of NPLs for the financial and economic activity. Private sector credit growth has slowed to 6 percent in 2015, from an average of 15 percent in 2005-14, owing in part to the deterioration in asset quality. Nonetheless, the banking system remained profitable, reflecting very large interest margins to compensate for high credit risk. The reported capital adequacy ratio was 23.9 percent in 2015 on average, well above the 8 percent regulatory requirement, though under-provisioning, weaknesses in loan classification, and related-party exposures may reduce bank's capacity to absorb losses.

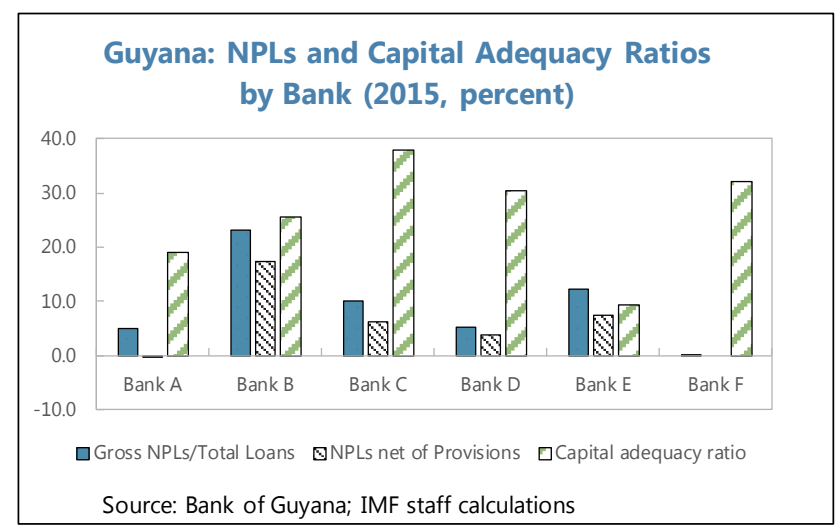

Resolution framework. As reported by the 2016 FSAP, prudential oversight by the BoG has improved, although some room for further strengthening remains. The authorities adopted a risk-based supervisory framework, and have been conducting quarterly single-factor stress tests and biennial comprehensive onsite supervisions. The supervisory perimeter was widened to include all major financial institutions. Loan classification and provisioning requirements are in force, although lower provisioning (20 percent) is permitted for secured loans, despite difficulties in collateral recovery. There are weaknesses in credit risk management, including on overdraft and related-party lending in some domestic banks. The credit bureau, established in 2013, continues to develop its database. The legal system does not appear supportive of effective NPL resolution: corporate insolvency and debt 
restructuring regime is absent, and insolvency petitions are not handled in the Commercial Court set up to quickly resolve commercial disputes.

Main impediments to resolution. The slowdown in economic activity has taken a toll on businesses, making debt servicing challenging. The judicial system is seen too slow and ineffective in enforcing contracts or in resolving disputes. In particular, the Commercial Court has few judges, and frequent adjournment of cases leads to excessive delays in debt recovery, up to 6 years or longer, which hinders banks' ability to quickly seize and resell property. Despite difficulties in collateral valuation and realization, banks continue to depend on collateral rather than cash flow as a source of repayment and can provision less for secured loans. Security rights associated with a loan, such as mortgage, cannot be transferred without re-registering the lien. Informational barriers remain; besides the credit bureau, there is no readily accessible source of information on borrowers, since the available public asset registers are manual in nature and inefficient. Deficiencies in public registers raise the cost of due diligence for banks. There is no secondary market for the sale of distressed assets.

Resolution strategies implemented and outcomes. Beside encouraging affected banks to reduce NPLs to no more than 5 percent, the BoG has not taken other measures to accelerate NPL resolution. It continues to monitor closely the strength of the financial system and reforms are expected to be guided by the findings of the recent FSAP. Banks seem wellplaced to effectively manage NPLs, with dedicated resources and NPL targets. Some banks have revamped their debt recovery department, intensified NPL monitoring, and revised their credit policies. Some banks have also worked out repayment plans, and promptly taken legal actions against defaulters. Loan write-offs, collateral disposal and portfolio sales/transfers to a private asset management company have been among the tools used for NPL reduction.

\section{Jamaica}

Jamaica was hit hard by the global financial crisis, which led to more than tripling of the NPL ratio from its pre-crisis level. However, the proactive measures undertaken by the authorities in the context of an ambitious reform program aimed at tackling macroeconomic imbalances and high public debt, and led to an improvement in the macro-prudential and institutional frameworks. This contributed to the strengthening of the macroeconomic environment and facilitated better credit underwriting and management practices by deposit taking institutions in a context of the gradual lowering of interest rates and sustained demand for credit, thereby paving the way for a normalization in the NPL ratio back to its pre-crisis levels.

Size, structure, and evolution of NPLs. Following the global financial crisis, the NPL ratio increased sharply from its pre-crisis level of about 2.5 percent in 2007 to nearly 9 percent of total loans in 2011. The most significant increases were observed in the personal, construction and the tourism sectors, which accounted for close to 80 percent of total NPLs in 2011. Subsequently, the country achieved a remarkable reduction in the NPL ratio to 
below 3 percent in 2016, largely reflecting the significant reduction in NPLs in the tourism and construction sectors.

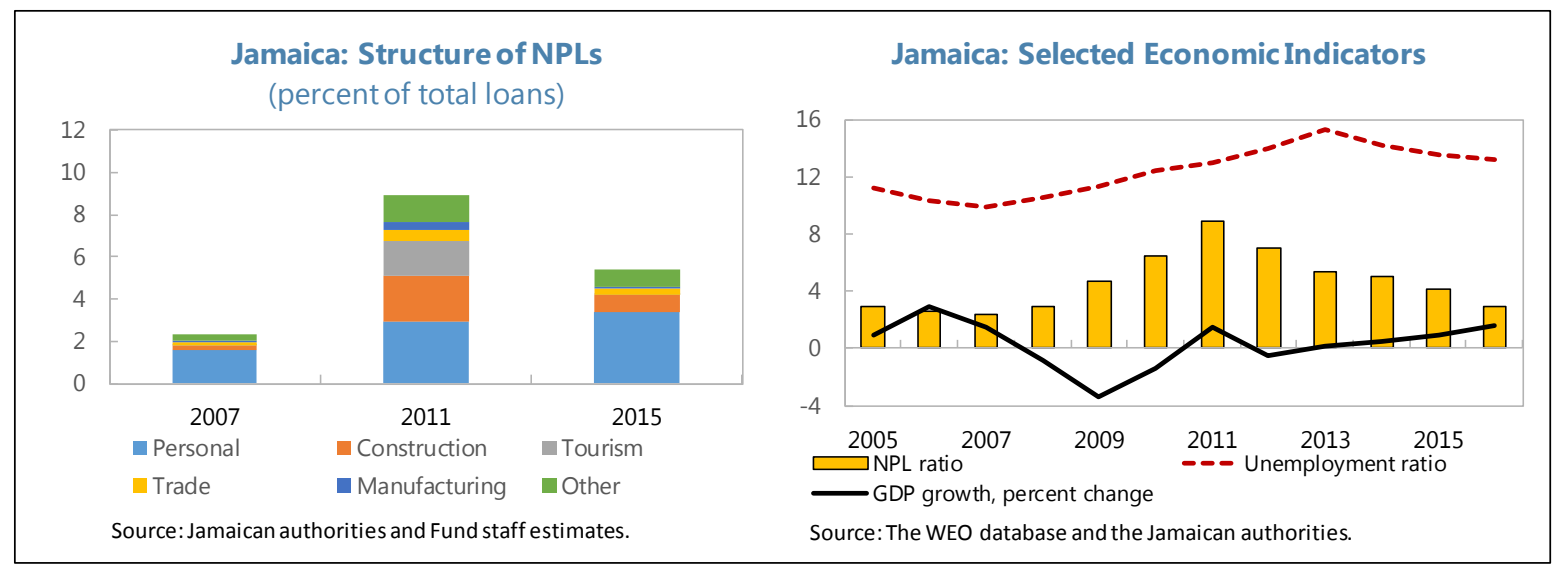

Key drivers of NPLs. The rise in NPLs was largely a result of a deteriorating macroeconomic environment in the aftermath of the global financial crisis. The subsequent economic recession reduced the commercial borrowers' capacity to service their debt, particularly in the tourism and construction sectors, resulting in higher delinquency rates amongst deposit taking institutions (DTIs). The increasing rate of unemployment also took a toll on personal incomes and households' ability to service their loans, pushing up delinquency rates for personal loans.

Implications of high NPLs. The rising NPLs during 2008-11 required greater levels of provisioning, thereby reducing the profitability of the banking system. The ROE declined from an average of 24 percent during 2005-2007 to an average 18 percent in subsequent years up to 2011. The rising NPLs coincided with a sharp slowdown in credit growth from 2008 to 2010 (a contraction in real terms for 20092010) as banks tightened their lending standards. However, real growth in credit has picked up since 2010, suggesting that the rise in NPLs did not produce a lasting

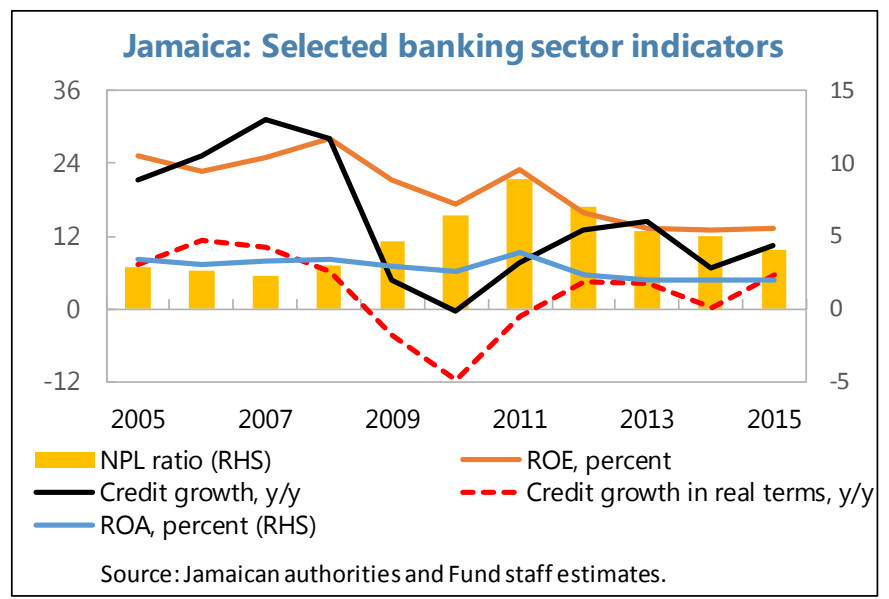
negative effect on financial intermediation.

Resolution strategies implemented and outcomes. The authorities took a range of proactive measures that were instrumental in reducing NPLs. 
- Strengthening regulatory/prudential framework. The supervisory authorities have been actively encouraging banks to adopt measures needed to address the deterioration in loan quality. Regulations required that all loans past due by more than 24 months must be fully provisioned. As a result, provisions have increased from 70 percent in 2010 to more than 110 percent in 2016. The banks also took active measures to resolve their stock of NPLs through corporate writeoffs (averaging 4.3 percent of NPL stock annually during 2012-

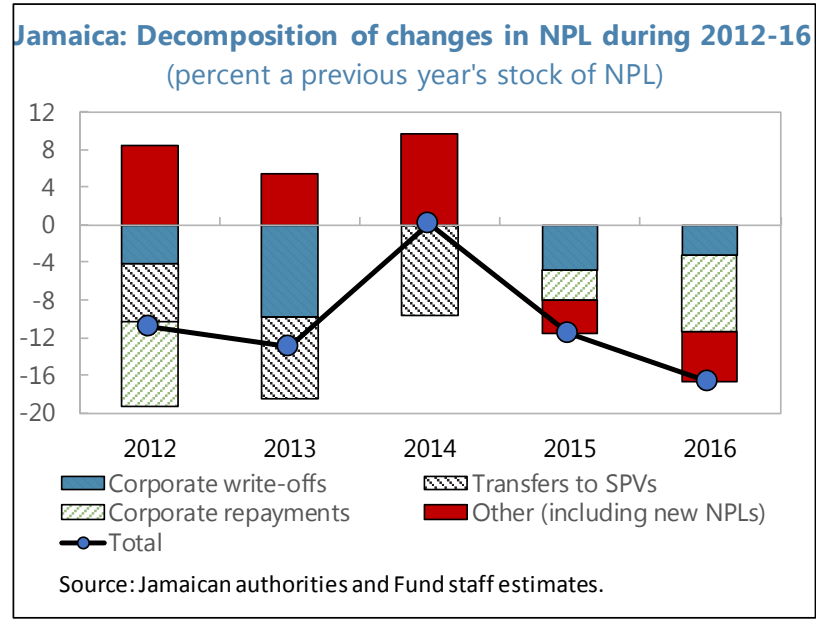
16), transfers to SPVs (averaging 8.2 percent of NPL stock annually during 2012-14), and corporate debt workouts (averaging 4.1 percent of NPL stock annually during 2012-16).

- $\quad$ Improving credit portfolio management by DTIs. The strengthened regulatory and prudential frameworks established a sound foundation for improved credit portfolio management by DTIs as evidenced in a reduction of new NPL flow (largely from the personal and SME sectors) during 2015-16. Specifically, new NPLs (which amounted to approximately 4.5 percent of the NPL stock annually) recorded an annual average decline of J\$1.1 billion over the 2015-16 period. Moreover, the total number of NPL accounts dropped by 2,152 per year on average during 2015-2016 in contrast to an annual average increase of 2,004 during 2012-2014. This turnaround in new NPLs reflected a fundamental shift in the credit underwriting and credit risk management practices of DTIs, which has been supported by improving macroeconomic conditions and sustained demand for credit by borrowers.

- $\quad$ Upgrading debt enforcement and insolvency framework. The authorities introduced a new bankruptcy law in 2014, with an objective to make insolvency less timeconsuming and costly, thereby maximizing recovery values.

- $\quad$ Addressing information gaps. The authorities introduced a central collateral registry in 2013 and operationalized credit bureaus in 2014, to support the financial intermediation process. Notably, the use of credit bureaus by credit information providers has expanded significantly since 2014 (see Table below). The availability of better borrower data from credit bureaus has also allowed DTIs to engage in more risk-based pricing and structuring of loans (i.e., by extending lower cost, longer-tenor and pre-approved loans to their 'blue-chip' customers with good credit history). In

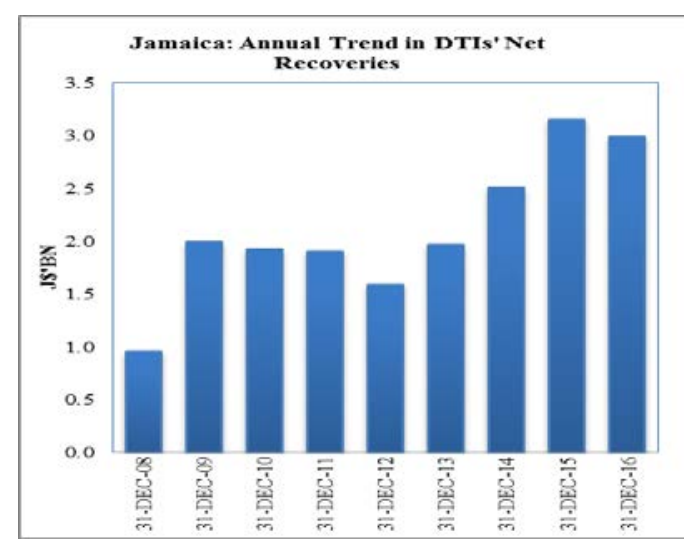


addition, credit bureaus have incentivized borrowers to settle delinquent debts so that they can improve their credit ratings and access loans on better terms.

- $\quad$ These positive developments in behavior patterns within the lending markets have played a key role in the reduction in new NPLs for 2015-16, while facilitating net loan write-offs and improving net recoveries (chart). All these measures, in addition to improvements in macroeconomic environment in the past several years, helped reduce the NPLs to below 3 percent in 2016-around pre-crisis levels.

\begin{tabular}{|c|c|c|c|}
\hline \multicolumn{4}{|c|}{ Summary of Credit Bureau Industry Trends in Jamaica: 2014-16 } \\
\hline Activity Indictors & 2014 & 2015 & 2016 \\
\hline $\begin{array}{l}\text { Number of credit information providers (CIPs) signed with } \\
\text { credit bureaus }\end{array}$ & 53 & 69 & 84 \\
\hline Number of CIPs submitting data to credit bureaus & 18 & 19 & 36 \\
\hline Number of CIPs pulling data from credit bureaus & 29 & 47 & 63 \\
\hline $\begin{array}{l}\text { Number of reports issued during the year (inclusive of free } \\
\text { reports) }\end{array}$ & 69,939 & 129,698 & 250,122 \\
\hline Number of free consumers reports issued & 1,093 & 2,241 & 5,765 \\
\hline $\begin{array}{l}\text { Number of account records in database of the credit bureau } \\
\text { with the largest number at year end }\end{array}$ & 703,405 & 846,350 & $1,070,168$ \\
\hline $\begin{array}{l}\text { Number of data subjects in database of the credit bureau } \\
\text { with the largest number at year end }\end{array}$ & 391,111 & 372,471 & 408,570 \\
\hline $\begin{array}{l}\text { Population coverage at year end, percent of population from } \\
18 \text { to } 74 \text { years of age } / 2\end{array}$ & 21.6 & 20.6 & 22.6 \\
\hline $\begin{array}{l}\text { Hit rate for CIPs using credit bureau with the highest rate at } \\
\text { year end, percent }\end{array}$ & 70.4 & 70.5 & 72.6 \\
\hline \multicolumn{4}{|c|}{$\begin{array}{l}\text { Source: Jamaican authorities. } \\
1 \text { Calculated as percentage of credit granting population covered by credit bureaus. The bureau } \\
\text { with the largest number of data subjects was chosen, with the population segment of ages } 18- \\
74 \text { as of } 2014 \text {. }\end{array}$} \\
\hline
\end{tabular}




\section{AnNeX II. Key Measures Implemented in the Past 3 Years to Resolve NPLs}

\section{Measures taken by country authorities}

- Mortgage relief program (Bahamas)

- Tighter prudential requirements and enforcement of changes to prudential regulations (loan classification and provisioning); restriction of banks from declaring, paying dividends and repatriating profits until all prior losses are written off, all impaired assets are adequately provisioned, and central bank directives are complied with (Belize)

- Introduction of a new insolvency regime (Jamaica)

- Establishment of an Asset Management Cooperation and new Banking and AMC Laws (ECCU)

- Establishment of a collections unit and hiring of delinquency officers and issuance of loan policy and procedures manual, recommendation of minimum annual write-offs (St Kitts and Nevis, for credit unions)

- Enactment of bankruptcy laws regarding receivership and development of procedures for the receivership (Trinidad and Tobago (TTO))

\section{Measures taken by banks}

- Prevention/prudential: Stricter lending criteria (Bahamas, Suriname, TTO); continuous review of credit analysis and close monitoring of credit portfolio to limit development of NPL (Guyana, Jamaica, Monserrat, Suriname); implementation of quality control unit and use of reporting mechanisms for proactive portfolio management (Guyana); close monitoring/follow-up of delinquency for early detection of deterioration and corrective measures (Bahamas, ECCU, Guyana, TTO); tighter loan delinquency/ adjudication management to mitigate migration to NPLs (Jamaica, TTO); tighter loan provisioning (Suriname, TTO)

- Restructuring: Refinancing/restructuring/repayment plans to foster remediation/ reinstatements/repayment (Bahamas, Belize, ECCU, Guyana, Jamaica, Suriname, TTO); accepting reduced payment arrangements (Barbados); restructuring to forgive/discount interest payments (Jamaica, Suriname); proactive approach in collection and restructuring of loans (Belize)

- Relief: Participating in mortgage relief plans by the government; forbearance agreements (Bahamas); aggressive approach to loan-loss provisioning and write-off (Belize); encouragement of settlement offers for long outstanding non-accruals (Guyana); write offs due to the age of the NPLs (Barbados)

- Recovery: Establishment of a specialized recovery unit (Belize, Guyana, Suriname); disposal of collateral to reduce debts (Suriname, TTO); follow up with the borrower rigorously for recovery of dues (Guyana); strengthened arrears management unit with required skills and resources (Jamaica); timely legal measures for recovery (TTO)

- Sales: Repricing/aggressive marketing of properties for sale (Belize, ECCU, Jamaica); financing to eligible customers to purchase bank's distressed properties (Bahamas); encouraging voluntary sales by owners and proactive selling approach for repossessed properties (Barbados); prepare legal processes for sale and foreclosure (Suriname, TTO); early sales of property when possible (Monserrat)

- Collection: Strengthened collection activity/methodology/tools, more focused attention on NPLs by specialized teams to work on resolution, taking legal action against delinquent customers to facilitate access to property by potential buyers (Bahamas, Guyana, Jamaica); undertake intensive collections (Suriname); enhanced focus on specific borrower categories and early collection action (Guyana, TTO); seek shorter legal processes, some work outs, and legal case resolutions (Barbados); various forms of litigation (foreclosure proceedings, seizures/repossession of movable assets, appointment of Receivers/Receiver-Managers, selected cases of settlement of indebtedness based on individual merits (Guyana).

- Other: Reviewing alternative measures for asset realization - e.g. wholesale, assigning more assets to realtors, etc. (Bahamas); training and updating policies/procedures (Belize); educating customers, including on negative effects of NPLs on financial profile (Jamaica) and on early warning signs (Suriname). 


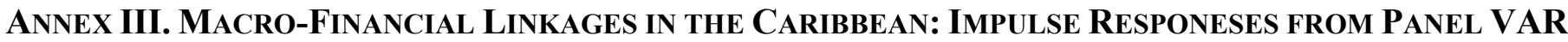

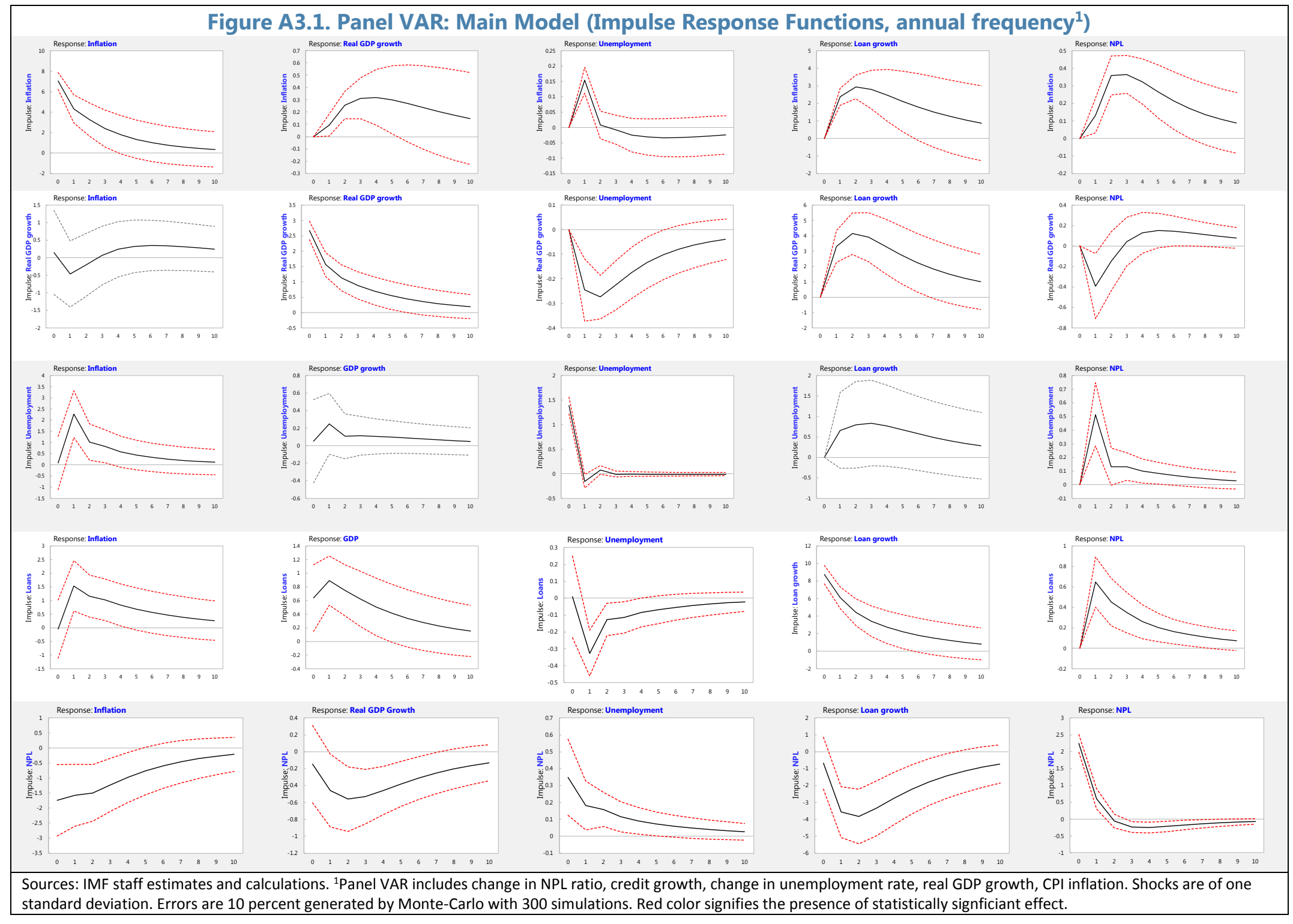




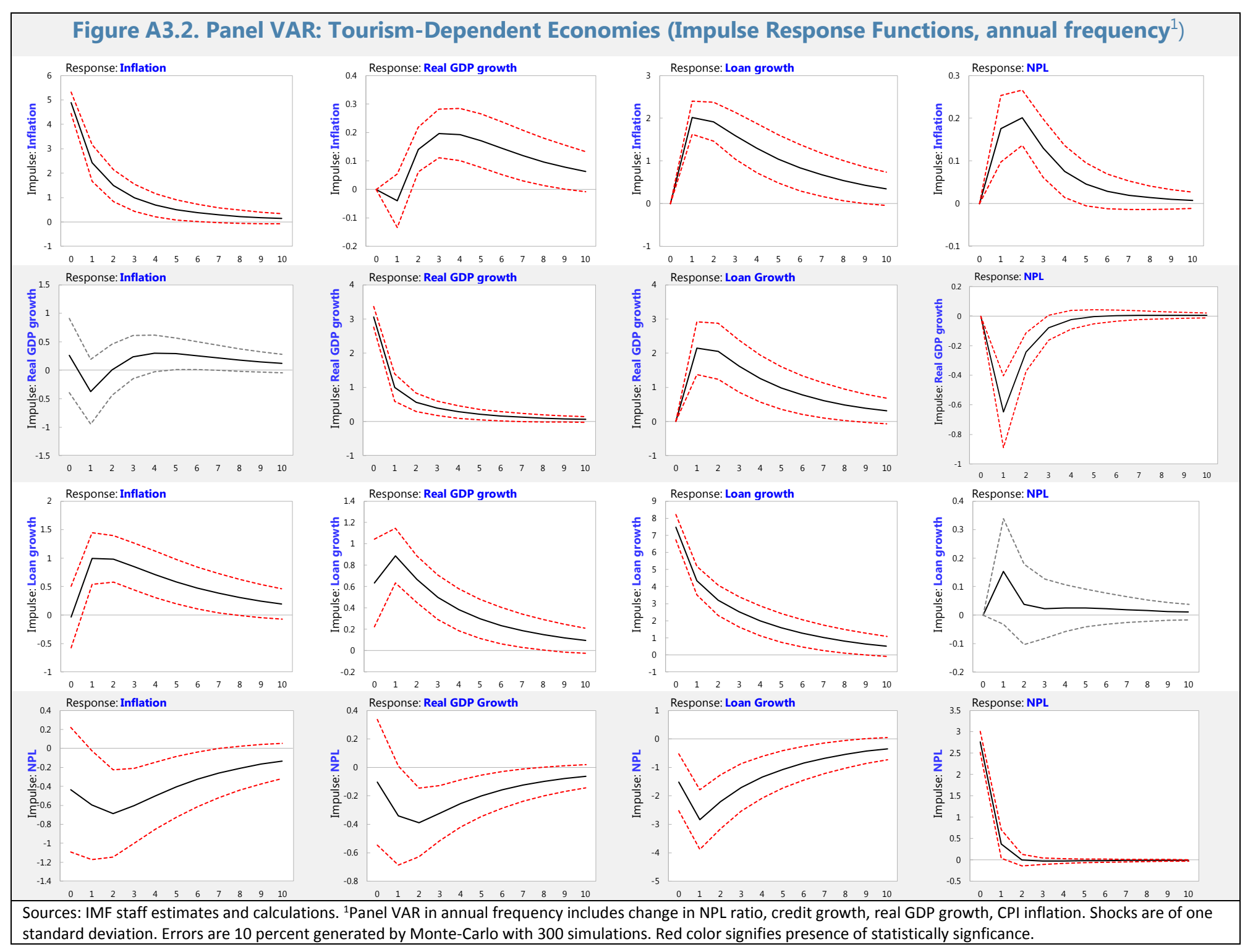




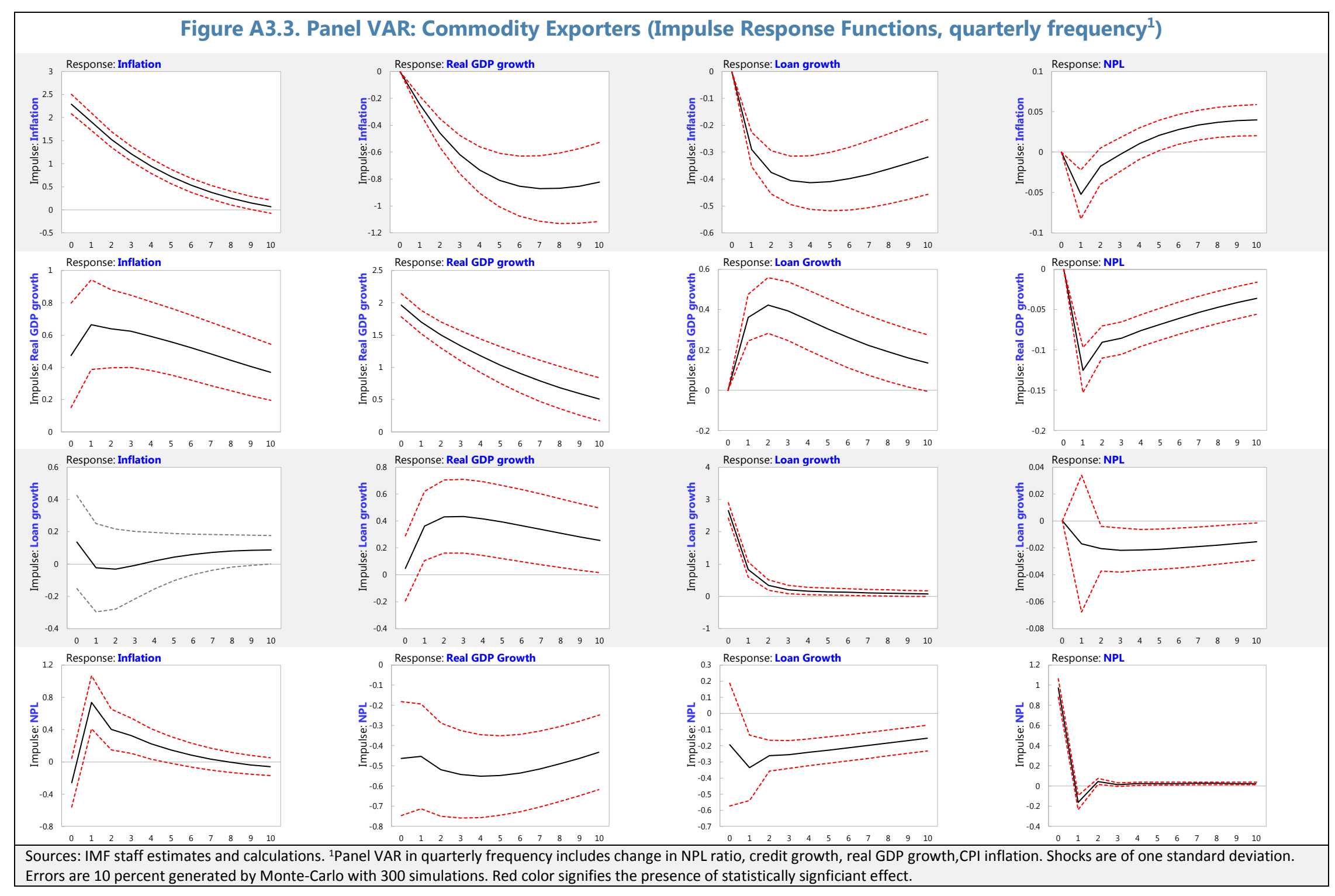


Figure A3.4. Panel VAR: Variance Decomposition

(Model for productive sectors, annual frequency, in percent)

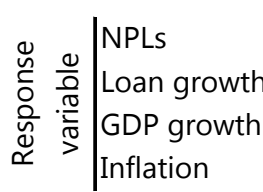

\begin{tabular}{|ccccc|}
\multicolumn{5}{c}{ Impulse variable } \\
\hline Horizon & NPLs & Loan growth & GDP growth & Inflation \\
\hline 2 & 72.8 & 2.1 & 23.3 & 1.8 \\
2 & 5.4 & 71.6 & 11.6 & 11.5 \\
2 & 1.1 & 0.9 & 86.4 & 11.6 \\
2 & 0.7 & 11.4 & 5.9 & 82.0 \\
\hline
\end{tabular}

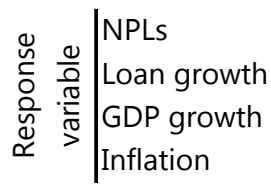

\begin{tabular}{ccccc|}
\multicolumn{5}{c}{ Impulse } \\
\hline Horizon & NPLs & Loan growth & GDP growth & Inflation \\
\hline 5 & 64.4 & 3.2 & 21.3 & 11.1 \\
5 & 5.2 & 66.5 & 16.6 & 11.7 \\
5 & 1.1 & 2.3 & 80.5 & 16.2 \\
5 & 1.2 & 15.7 & 12.8 & 70.3 \\
\hline
\end{tabular}

Source: authors' estimates and calculations. 


\section{ANNEX IV. RESUlts OF THE DETAILED EMPIRICAL ANALYSES AND SURVEY RESPONSES}

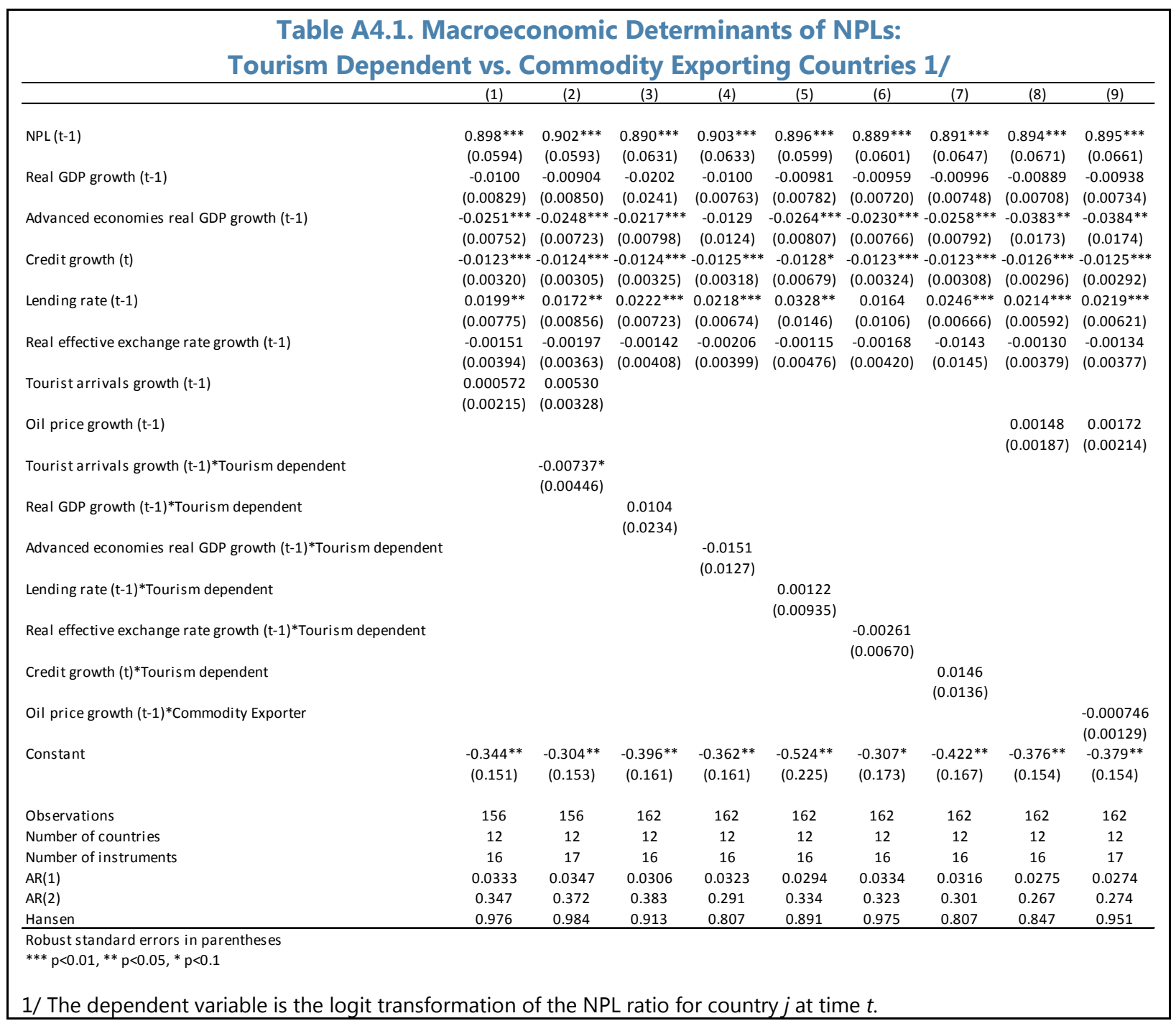




\begin{tabular}{|c|c|c|c|c|c|}
\hline \multicolumn{6}{|c|}{ Table A4.2. Bank-level Determinants of NPLs 1/ } \\
\hline & $(1)$ & $(2)$ & $(3)$ & $(4)$ & $(5)$ \\
\hline \multirow[t]{2}{*}{$N P L(t-1)$} & $0.646^{* * *}$ & $0.635^{* * *}$ & $0.631 * * *$ & $0.607^{* * *}$ & $0.608 * * *$ \\
\hline & $(0.0650)$ & $(0.0661)$ & $(0.0630)$ & $(0.0749)$ & $(0.0736)$ \\
\hline \multirow[t]{2}{*}{ NPL $(t-2)$} & $0.171^{* * *}$ & $0.166^{* * *}$ & $0.190 * * *$ & $0.177^{* * *}$ & $0.171 * * *$ \\
\hline & $(0.0545)$ & $(0.0528)$ & $(0.0569)$ & $(0.0618)$ & $(0.0606)$ \\
\hline \multirow[t]{2}{*}{ Advanced economies real GDP growth (t-1) } & $-0.00703 * *$ & -0.00532 & $-0.00704 * *$ & -0.00439 & -0.00435 \\
\hline & $(0.00326)$ & $(0.00332)$ & $(0.00330)$ & $(0.00358)$ & $(0.00394)$ \\
\hline \multirow[t]{2}{*}{ Tourism growth $(\mathrm{t}-1)$} & & -0.000403 & & & \\
\hline & & $(0.000458)$ & & & \\
\hline \multirow[t]{2}{*}{ Credit growth $(t)$} & & & $-0.00452^{* * *}$ & $-0.00450 * * *$ & $-0.00477^{* * *}$ \\
\hline & & & $(0.00100)$ & $(0.00105)$ & $(0.00118)$ \\
\hline \multirow[t]{2}{*}{ Lending rate $(t-1)$} & & & & -0.0436 & -0.0386 \\
\hline & & & & $(0.0341)$ & $(0.0332)$ \\
\hline \multirow[t]{2}{*}{ Real effective exchange rate growth ( $t-1)$} & & & & & $-4.17 e-05$ \\
\hline & & & & & $(0.00164)$ \\
\hline \multirow[t]{2}{*}{ Constant } & $-0.475^{*}$ & $-0.514^{*}$ & -0.427 & -0.0687 & -0.132 \\
\hline & $(0.272)$ & $(0.270)$ & $(0.273)$ & $(0.252)$ & $(0.247)$ \\
\hline Observations & 3,825 & 3,591 & 3,709 & 3,709 & 3,671 \\
\hline Number of banks & 71 & 70 & 71 & 71 & 71 \\
\hline Number of instruments & 7 & 8 & 10 & 13 & 14 \\
\hline $\operatorname{AR}(1)$ & $1.88 \mathrm{e}-07$ & $2.59 e-07$ & $3.58 e-07$ & $4.40 \mathrm{e}-07$ & $5.60 e-07$ \\
\hline $\operatorname{AR}(2)$ & 0.569 & 0.909 & 0.437 & 0.537 & 0.641 \\
\hline Hansen & 0.495 & 0.202 & 0.485 & 0.563 & 0.175 \\
\hline \multicolumn{6}{|l|}{ Robust standard errors in parentheses } \\
\hline \multicolumn{6}{|l|}{$* * * p<0.01, * * p<0.05, * p<0.1$} \\
\hline
\end{tabular}




\begin{tabular}{|c|c|c|c|c|c|}
\hline & $(1)$ & $(2)$ & $(3)$ & $(4)$ & $(5)$ \\
\hline$N P L(t-1)$ & $\begin{array}{c}0.648^{* * *} \\
(0.0638)\end{array}$ & $\begin{array}{c}0.635^{* * *} \\
(0.0661)\end{array}$ & $\begin{array}{c}0.627^{* * *} \\
(0.0676)\end{array}$ & $\begin{array}{c}0.630 * * * \\
(0.0670)\end{array}$ & $\begin{array}{c}0.628^{* * *} \\
(0.0618)\end{array}$ \\
\hline$N P L(t-2)$ & $\begin{array}{c}0.171^{* * *} \\
(0.0540)\end{array}$ & $\begin{array}{c}0.166^{* * *} \\
(0.0528)\end{array}$ & $\begin{array}{c}0.163^{* * *} \\
(0.0531)\end{array}$ & $\begin{array}{c}0.164^{* * *} \\
(0.0532)\end{array}$ & $\begin{array}{c}0.183^{* * *} \\
(0.0573)\end{array}$ \\
\hline Advanced economies real GDP growth (t-1) & $\begin{array}{c}0.00417 \\
(0.00927)\end{array}$ & $\begin{array}{c}-0.00541 \\
(0.00334)\end{array}$ & $\begin{array}{l}-0.00465 \\
(0.00334)\end{array}$ & $\begin{array}{l}-0.00528 \\
(0.00367)\end{array}$ & $\begin{array}{c}-0.00548 \\
(0.00364)\end{array}$ \\
\hline Tourism growth (t-1) & & $\begin{array}{l}0.000246 \\
(0.00106)\end{array}$ & $\begin{array}{c}-0.000315 \\
(0.000445)\end{array}$ & $\begin{array}{c}-0.000281 \\
(0.000447)\end{array}$ & $\begin{array}{l}-0.000203 \\
(0.000432)\end{array}$ \\
\hline Lending rate $(\mathrm{t}-1)$ & & & $\begin{array}{c}0.00149 \\
(0.00715)\end{array}$ & $\begin{array}{l}-0.00824 \\
(0.00717)\end{array}$ & $\begin{array}{c}-0.00360 \\
(0.00605)\end{array}$ \\
\hline Real effective exchange rate growth (t-1) & & & & $\begin{array}{l}0.000668 \\
(0.00215)\end{array}$ & $\begin{array}{c}6.99 \mathrm{e}-06 \\
(0.00148)\end{array}$ \\
\hline Credit growth $(\mathrm{t})$ & & & & & $\begin{array}{c}-0.00350 * * \\
(0.00168)\end{array}$ \\
\hline Advanced economies real GDP growth $(\mathrm{t}-1)^{*}$ Foreign bank & $\begin{array}{l}-0.0172 \\
(0.0126)\end{array}$ & & & & \\
\hline Tourism growth $(\mathrm{t}-1) *$ Foreign bank & & $\begin{array}{r}-0.000992 \\
(0.00124)\end{array}$ & & & \\
\hline Lending rate $(\mathrm{t}-1) *$ Foreign bank & & & $\begin{array}{c}-0.0135^{*} \\
(0.00706)\end{array}$ & & \\
\hline Real effective exchange rate growth $(\mathrm{t}-1)^{*}$ Foreign bank & & & & $\begin{array}{l}-0.00157 \\
(0.00283)\end{array}$ & \\
\hline Credit growth $(\mathrm{t})$ *Foreign bank & & & & & $\begin{array}{c}-0.00275 \\
(0.00265)\end{array}$ \\
\hline Constant & $\begin{array}{c}-0.206 \\
(0.238)\end{array}$ & $\begin{array}{l}-0.0190 \\
(0.270)\end{array}$ & $\begin{array}{c}-0.00989 \\
(0.261)\end{array}$ & $\begin{array}{c}-0.00514 \\
(0.245)\end{array}$ & $\begin{array}{c}-0.563^{* * *} \\
(0.208)\end{array}$ \\
\hline Observations & 3,654 & 3,453 & 3,453 & 3,453 & 3,429 \\
\hline Number of banks & 66 & 66 & 66 & 66 & 66 \\
\hline Number of instruments & 9 & 10 & 11 & 12 & 15 \\
\hline$A R(1)$ & $7.54 \mathrm{e}-07$ & $7.58 \mathrm{e}-07$ & $8.26 \mathrm{e}-07$ & $7.78 e-07$ & $1.34 \mathrm{e}-06$ \\
\hline $\operatorname{AR}(2)$ & 0.125 & 0.0148 & 0.0141 & 0.0139 & 0.530 \\
\hline Hansen & 0.313 & 0.626 & 0.617 & 0.629 & 0.411 \\
\hline
\end{tabular}

Robust standard errors in parentheses 
Table A4.4. Bank-Level Determinants of NPLs: Bank Performance: Domestic vs. ForeignOwned Banks

\begin{tabular}{|c|c|c|c|c|c|c|c|c|c|c|}
\hline & (1) & (2) & (3) & (4) & (5) & (6) & (7) & (8) & (9) & (10) \\
\hline NPL (t-1) & $\begin{array}{l}0.625 * * * \\
(0.0676)\end{array}$ & $\begin{array}{l}0.606 * * * \\
(0.0726)\end{array}$ & $\begin{array}{c}0.627^{* * *} \\
(0.0698)\end{array}$ & $\begin{array}{c}0.597^{* * *} \\
(0.0783)\end{array}$ & $\begin{array}{l}0.593 * * * \\
(0.0783)\end{array}$ & $\begin{array}{c}0.780^{* * *} \\
(0.0854)\end{array}$ & $\begin{array}{c}0.783^{* * *} \\
(0.0887)\end{array}$ & $\begin{array}{c}0.585^{* * *} \\
(0.0862)\end{array}$ & $\begin{array}{l}0.640 * * * \\
(0.0661)\end{array}$ & $\begin{array}{l}0.732^{* * *} \\
(0.0861)\end{array}$ \\
\hline NPL (t-2) & $\begin{array}{l}0.152^{* * *} \\
(0.0510)\end{array}$ & $\begin{array}{l}0.144 * * * \\
(0.0527)\end{array}$ & $\begin{array}{l}0.141^{* * *} \\
(0.0532)\end{array}$ & $\begin{array}{l}0.146^{* * *} \\
(0.0545)\end{array}$ & $\begin{array}{l}0.124 * * \\
(0.0554)\end{array}$ & $\begin{array}{c}0.0513 \\
(0.0679)\end{array}$ & $\begin{array}{c}0.0378 \\
(0.0688)\end{array}$ & $\begin{array}{c}0.150 * * * \\
(0.0543)\end{array}$ & $\begin{array}{l}0.144 * * * \\
(0.0530)\end{array}$ & $\begin{array}{l}0.190^{* * *} \\
(0.0527)\end{array}$ \\
\hline Advanced economies real GDP growth (t-1) & $\begin{array}{c}-0.00594^{*} \\
(0.00307)\end{array}$ & $\begin{array}{c}-0.00679 * * \\
(0.00336)\end{array}$ & $\begin{array}{c}-0.00481 \\
(0.00344)\end{array}$ & $\begin{array}{c}-0.00507 \\
(0.00343)\end{array}$ & $\begin{array}{l}-0.00539 \\
(0.00396)\end{array}$ & $\begin{array}{c}-0.00537 \\
(0.00392)\end{array}$ & $\begin{array}{c}-0.00414 \\
(0.00342)\end{array}$ & $\begin{array}{c}-0.00819 \\
(0.00621)\end{array}$ & $\begin{array}{c}-0.00525 \\
(0.00369)\end{array}$ & $\begin{array}{c}-0.0109^{* * *} \\
(0.00420)\end{array}$ \\
\hline Credit growth $(t)$ & $\begin{array}{c}-0.00435^{* * *} \\
(0.000894)\end{array}$ & $\begin{array}{c}-0.00418^{* * *} \\
(0.000958)\end{array}$ & $\begin{array}{c}-0.00480 * * * \\
(0.000940)\end{array}$ & $\begin{array}{c}-0.00390 * * * \\
(0.00101)\end{array}$ & $\begin{array}{c}-0.00494 * * * \\
(0.00117)\end{array}$ & $\begin{array}{c}-0.00358^{* * *} \\
(0.00127)\end{array}$ & $\begin{array}{c}-0.00379 * * * \\
(0.00112)\end{array}$ & $\begin{array}{c}-0.00498^{* * *} \\
(0.00146)\end{array}$ & $\begin{array}{c}-0.00506^{* * *} \\
(0.00115)\end{array}$ & $\begin{array}{c}-0.00280 * * * \\
(0.00101)\end{array}$ \\
\hline Return on assets $(t)$ & $\begin{array}{c}-0.0163^{* * *} \\
(0.00606)\end{array}$ & & & $\begin{array}{c}-0.0159 * * \\
(0.00802)\end{array}$ & $\begin{array}{l}-0.0148 * \\
(0.00789)\end{array}$ & $\begin{array}{l}0.000760 \\
(0.00442)\end{array}$ & $\begin{array}{l}0.000727 \\
(0.00409)\end{array}$ & $\begin{array}{c}-0.0158^{*} \\
(0.00838)\end{array}$ & $\begin{array}{c}-0.0103 \\
(0.00852)\end{array}$ & $\begin{array}{c}-0.0123 \\
(0.00754)\end{array}$ \\
\hline Return on equity (t) & & $\begin{array}{c}-0.00132 \\
(0.000917)\end{array}$ & & & & & & & & \\
\hline Net interest margin $(\mathrm{t})$ & & & $\begin{array}{l}-0.0650 \\
(0.0396)\end{array}$ & & & & & & & \\
\hline Capital Adequacy Ratio (t) & & & & $\begin{array}{c}-0.00803^{*} \\
(0.00470)\end{array}$ & $\begin{array}{c}-0.00277 \\
(0.00413)\end{array}$ & $\begin{array}{c}0.00867 \\
(0.00798)\end{array}$ & $\begin{array}{c}0.0103 \\
(0.00900)\end{array}$ & $\begin{array}{c}-0.00235 \\
(0.00405)\end{array}$ & & \\
\hline Loan-to-deposit ratio & & & & & $\begin{array}{c}-0.00477 \\
(0.00738)\end{array}$ & & & & & \\
\hline Expense-to-assets ratio & & & & & & $\begin{array}{c}0.0921 \\
(0.0609)\end{array}$ & $\begin{array}{c}0.0494 \\
(0.0505)\end{array}$ & & & \\
\hline Income-to-expenses ratio & & & & & & $\begin{array}{l}-0.177^{*} \\
(0.0985)\end{array}$ & $\begin{array}{l}0.0765 \\
(0.203)\end{array}$ & & & \\
\hline Total assets (In) & & & & & & & & $\begin{array}{l}0.0711 \\
(0.123)\end{array}$ & & \\
\hline Loans to households (in percent of total) & & & & & & & & & $\begin{array}{r}-0.000305 \\
(0.00884)\end{array}$ & \\
\hline Foreign currency loans (in percent of total) & & & & & & & & & & $\begin{array}{l}-3.56 \mathrm{e}-06 \\
(2.91 \mathrm{e}-06)\end{array}$ \\
\hline Return on assets $(\mathrm{t}){ }^{*}$ Foreign bank & $\begin{array}{l}0.00449 \\
(0.0111)\end{array}$ & & & & & & & & & \\
\hline Return on equity $(\mathrm{t}){ }^{*}$ Foreign bank & & $\begin{array}{c}0.00107 \\
(0.000952)\end{array}$ & & & & & & & & \\
\hline Net interest margin $(t)^{*}$ Foreign bank & & & $\begin{array}{l}-0.0374 \\
(0.0810)\end{array}$ & & & & & & & \\
\hline Capital Adequacy Ratio (t)*Foreign bank & & & & $\begin{array}{c}0.00602 \\
(0.00705)\end{array}$ & & & & & & \\
\hline Loan-to-deposit ratio*Foreign bank & & & & & $\begin{array}{l}-0.00167 \\
(0.00712)\end{array}$ & & & & & \\
\hline Expense-to-assets ratio*Foreign bank & & & & & & $\begin{array}{c}-0.107 \\
(0.0858)\end{array}$ & & & & \\
\hline Income-to-expenses ratio*Foreign bank & & & & & & & $\begin{array}{l}-0.263 \\
(0.239)\end{array}$ & & & \\
\hline Total assets $(\mathrm{In}) *$ Foreign bank & & & & & & & & $\begin{array}{l}-0.0226 \\
(0.0170)\end{array}$ & & \\
\hline \multicolumn{2}{|c|}{ Loans to households (in percent of total)*Foreign bank } & & & & & & & & $\begin{array}{l}-0.00310 \\
(0.00631)\end{array}$ & \\
\hline \multicolumn{2}{|c|}{ Foreign currency loans (in percent of total)*Foreign bank } & & & & & & & & & $\begin{array}{c}5.11 \mathrm{e}-05 \\
(6.75 \mathrm{e}-05)\end{array}$ \\
\hline Constant & $\begin{array}{c}-0.526^{* *} \\
(0.265)\end{array}$ & $\begin{array}{c}-0.601^{* *} \\
(0.286)\end{array}$ & $\begin{array}{c}-0.458^{*} \\
(0.256)\end{array}$ & $\begin{array}{l}-0.571^{*} \\
(0.306)\end{array}$ & $\begin{array}{c}-0.229 \\
(0.207)\end{array}$ & $\begin{array}{l}-0.360^{*} \\
(0.216)\end{array}$ & $\begin{array}{c}-0.523^{*} \\
(0.283)\end{array}$ & $\begin{array}{l}-1.260 \\
(1.607)\end{array}$ & $\begin{array}{l}-0.405 \\
(0.309)\end{array}$ & $\begin{array}{l}-0.155 \\
(0.200)\end{array}$ \\
\hline Observations & 3,508 & 3,363 & 3,286 & 3,063 & 3,063 & 766 & 766 & 3,063 & 3,283 & 948 \\
\hline Number of banks & 71 & 66 & 62 & 62 & 62 & 22 & 22 & 62 & 62 & 28 \\
\hline Number of instruments & 16 & 16 & 16 & 19 & 22 & 25 & 25 & 22 & 19 & 19 \\
\hline $\operatorname{AR}(1)$ & $5.55 e-07$ & $8.28 \mathrm{e}-07$ & $1.40 \mathrm{e}-06$ & $3.20 \mathrm{e}-06$ & $1.70 \mathrm{e}-06$ & 0.00983 & 0.0104 & $1.97 \mathrm{e}-06$ & $1.52 \mathrm{e}-06$ & 0.000963 \\
\hline $\operatorname{AR}(2)$ & 0.898 & 0.699 & 0.975 & 0.630 & 0.207 & 0.566 & 0.655 & 0.827 & 0.958 & 0.493 \\
\hline 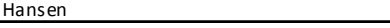 & 0.481 & 0.740 & 0.836 & 0.657 & 0.385 & 0.774 & 0.880 & 0.716 & 0.397 & 0.939 \\
\hline
\end{tabular}


Table A4.5. Obstacles to NPL Resolution Related to Supervisory Framework and Distressed Debt Market ${ }^{1}$

(in percent of respondents)

\begin{tabular}{|c|c|c|c|}
\hline & Yes & No & N.A. \\
\hline \multicolumn{4}{|l|}{ 1. Supervisory Framework } \\
\hline \multicolumn{4}{|l|}{ 1.1. Banks } \\
\hline \multicolumn{4}{|l|}{ 1.1.1 NPL management issues } \\
\hline $\begin{array}{l}\text { Do most banks have dedicated NPL workout units or are they required to separate NPL management } \\
\text { from loan origination and performing loan services? }\end{array}$ & 100 & 0 & 0 \\
\hline Are banks able to outsource NPL management (special servicers, agreements with asset managers)? & 86 & 14 & 0 \\
\hline Are banks required to have NPL management strategies/action plans or targets for NPL reduction? & 100 & 0 & 0 \\
\hline Is there a mechanism for interbank coordination on individual debtor cases? & 29 & 71 & 0 \\
\hline Is there a mechanism for coordination between private and public creditors on individual debtor cases? & 14 & 86 & 0 \\
\hline Do banks have adequate NPL restructuring toolkit and capacity to use it? & 86 & 0 & 14 \\
\hline Have any of the following restructuring tools been used during the past 3 years: & 100 & 0 & 0 \\
\hline - interest only loans & 100 & 0 & 0 \\
\hline - debt/equity swaps & 29 & 43 & 29 \\
\hline - reducing repayments by warehousing a proportion of debt & 86 & 0 & 14 \\
\hline - performance based write-off of a proportion of the debt & 86 & 0 & 14 \\
\hline - other tools & 43 & 14 & 43 \\
\hline Have any of the following mechanisms of NPL disposals been used in the past 3 years: & 100 & 0 & 0 \\
\hline - portfolio sales & 57 & 43 & 0 \\
\hline - transfer to private or public AMCs & 57 & 29 & 14 \\
\hline - write-offs & 86 & 14 & 0 \\
\hline - other mechanisms & 29 & 29 & 43 \\
\hline \multicolumn{4}{|l|}{ 1.1.2 Collateral and related issues } \\
\hline Are collateral valuations typically based on market prices (as opposed to tax or last transaction value)? & 100 & 0 & 0 \\
\hline Is there a requirement to apply a real estate valuation standard? & 57 & 43 & 0 \\
\hline Are bilateral sales permitted for repossessed assets? & 86 & 0 & 14 \\
\hline Is information on upcoming sales/auctions publicly available? & 86 & 0 & 14 \\
\hline Are there any blanket bans on sales/auctions in place? & 14 & 71 & 14 \\
\hline \multicolumn{4}{|l|}{ 1.1.3 Bank Capital Adequacy } \\
\hline $\begin{array}{l}\text { Have banks been subject to granular asset quality reviews during 2013-15 and raised capital to address } \\
\text { any identified shortfalls? }\end{array}$ & 71 & 29 & 0 \\
\hline Have banks been able to fulfill any capital needs arising during $2013-15$ by tapping the private markets? & 43 & 43 & 14 \\
\hline Have banks been forced to dispose of assets during $2013-15$ in order to deleverage? & 14 & 86 & 0 \\
\hline $\begin{array}{l}\text { Does the regulator assess the conservatism and consistency of loan loss provisions across banks as part } \\
\text { of on-site inspections? }\end{array}$ & 100 & 0 & 0 \\
\hline \multicolumn{4}{|l|}{ 1.2. Supervisors } \\
\hline Have supervisors undertaken a thematic review of banks' NPL management capacity during 2013-15? & 86 & 14 & 0 \\
\hline Have supervisors issued formal guidelines to banks on NPL management practices? & 86 & 14 & 0 \\
\hline $\begin{array}{l}\text { Does the on-site supervision team include specialists/advisors with NPL collection and workout } \\
\text { experience? }\end{array}$ & 57 & 43 & 0 \\
\hline Is there a licensing and regulatory regime in place to enable non-banks to own or manage NPLs? & 14 & 86 & 0 \\
\hline Have supervisors provided additional incentives for NPL write-offs? & 71 & 29 & 0 \\
\hline $\begin{array}{l}\text { Have supervisors issued regulations regarding provisioning (or communicated regulatory expectations in } \\
\text { case of provisions under IFRS)? }\end{array}$ & 86 & 14 & 0 \\
\hline Have supervisors performed assessments of collateral valuation practices? & 71 & 29 & 0 \\
\hline \multicolumn{4}{|l|}{ 2. Markets for NPLs } \\
\hline Are third party banks, including foreign banks, allowed to buy NPLs from domestic banks? & 86 & 14 & 0 \\
\hline Are institutional investors (non-banks) allowed to buy NPLs from domestic banks? & 86 & 14 & 0 \\
\hline $\begin{array}{l}\text { Are foreign (non-resident) institutional investors, including both banks and non-banks, allowed to } \\
\text { buy/own NPLs? }\end{array}$ & 86 & 0 & 14 \\
\hline Can banks set up private asset management companies in cooperation with investment firms? & 86 & 0 & 14 \\
\hline Are there active AMCs operating in the country? & 71 & 29 & 0 \\
\hline
\end{tabular}

\section{CInternational Monetary Fund. Not for Redistribution}


Table A4.6. Obstacles to NPL Resolution Related to Information Framework and the Debt enforcement and Insolvency Regime ${ }^{1}$

(in percent of respondents)

\begin{tabular}{lll}
\hline 1. INFORMATION FRAMEWORK & Yes N.A. No \\
\hline 1.1. Public RegterS
\end{tabular}

\subsection{Public Registers}

(i) Limitations of credit bureaus:

Are there credit bureaus or registries?

- is there scoring for borrowers?

- does it include information on connected borrowers (family or business links)?

(ii) Limitations of the cadastral system (land registry):

Is there a cadastral system (land registry?)

- Are creditors able to obtain the data?

$\begin{array}{rrr}38 & 63 & 0 \\ 38 & 0 & 63 \\ 13 & 25 & 63 \\ 100 & 0 & 0 \\ 88 & 0 & 13 \\ & & \\ 50 & 50 & 0 \\ 13 & 50 & 38 \\ 38 & 13 & 50 \\ & & \\ 38 & 63 & 0 \\ 38 & 13 & 50 \\ 38 & 0 & 63\end{array}$

(iii) Limitations of public asset register:

Is there a public asset register?

- is the general public able to conduct searches?

- Are the owner and the asset characteristics recorded?

(iv) Limitations of real estate transaction price public registers

Is there a register capturing prices of real estate transactions?

- are prices of all real estate transactions recorded?

- is the general public able to conduct searches?

\subsection{Consumer and Data Protection}

- Are there any restrictions on recording/sharing of personal information for debt workout

purposes (e.g. name, date of birth, social security number, postcode, income, assets, other

\section{DEBT ENFORCEMENT AND INSOLVENCY REGIMES}

\subsection{Corporate Insolvency and Debt Restructuring Regime}

Is there a corporate bankruptcy/insolvency regime (credible threat of bankruptcy)?

Are there fast-track procedure for approval of debtor/creditor agreed restructuring plans?

Is there an out-of-court settlement mechanism?

Is it possible to limit shareholders' decisions as part of business restructuring?

Can assets of a company (under debt restructuring) be sold through auctions, open-market

bilateral sales or other means?

\subsection{Household Debt Resolution Regime}

Is there a bankruptcy regime (credible threat of bankruptcy) for consumers/households?

- are individual entrepreneurs eligible for that process (as opposed to only households)?

Is there an out-of-court settlement/mediation mechanism?

2.3. Judicial System (implementation of the debt enforcement and insolvency regimes)

Are there specialized courts or judges that only deal with insolvency issues?

Are there set time requirements for insolvency process?

\section{TAX REGIME}

Are there tax deductions for loan loss provisioning?

Is there a tax loss carry forward mechanism such as a deferred tax asset?

Are there tax deductions for loan write-off?

Are there tax deductions for collateral sale?

Are debtors charged capital gains tax upon debt write-off/restructuring of their debts at more

favorable terms?

Can public creditors provide debt write-off?

\section{OTHER INSTITUTIONAL OR POLICY ISSUES}

Are there blanket bans (moratoria) on foreclosures or auctions?

Are there any groups protected from the insolvency/debt enforcement laws motivated by political choices?

Are there established mechanisms for coordination among relevant stakeholders on the issues of NPL resolution?

Has the government taken specific measures to tackle debtors that can afford to pay but choose not to?

$50 \quad 38 \quad 13$

$\begin{array}{rrr} & & \\ 88 & 0 & 13 \\ 25 & 63 & 13 \\ 50 & 38 & 13 \\ 25 & 38 & 38 \\ 63 & 25 & 13\end{array}$

$\begin{array}{lll}63 & 25 & 13 \\ 50 & 38 & 13\end{array}$

25

$25 \quad 25 \quad 50$

$25 \quad 50 \quad 25$

$25 \quad 50 \quad 25$

$50 \quad 25 \quad 25$

$25 \quad 50 \quad 25$

$\begin{array}{lll}0 & 75 & 25\end{array}$

$13 \quad 63 \quad 25$

$50 \quad 0 \quad 50$

\begin{tabular}{rrr}
100 & 0 & 0 \\
100 & 0 & 0 \\
13 & 88 & 0 \\
13 & 88 & 0 \\
\hline
\end{tabular}

Source: National authorities.

1/ Compiled from responses from 8 countries: The Bahamas, Belize, Guyana, Jamaica, Montserrat, St. Kitts and Nevis, Suriname and Trinidad and Tobago. 